\title{
Evaluation of Chemical Data from Selected Sites in the Surface-Water Ambient Monitoring Program (SWAMP) in Florida
}

By Brian G. Katz and Jerilyn J. Collins

U.S. Geological Survey

Open-File Report 98-559

Prepared in cooperation with the

FLORIDA DEPARTMENT OF ENVIRONMENTAL PROTECTION

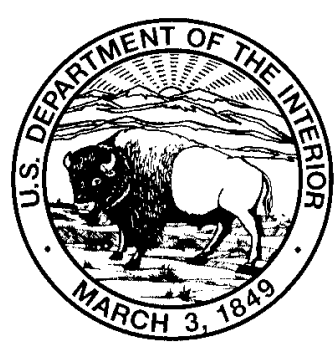

Tallahassee, Florida

1998 


\title{
U.S. DEPARTMENT OF THE INTERIOR BRUCE BABBITT, Secretary
}

\author{
U.S. GEOLOGICAL SURVEY
}

Thomas J. Casadevall, Acting Director

Any use of trade, product, or firm names in this publication is for descriptive purposes only and does not imply endorsement by the U.S. Geological Survey.

For additional information write to:

District Chief

U.S. Geological Survey

Suite 3015

227 N. Bronough Street

Tallahassee, FL 32301
Copies of this report can be purchased from:

U.S. Geological Survey

Branch of Information Services

Box 25286

Denver, CO 80225

800-USA-MAPS 


\section{CONTENTS}

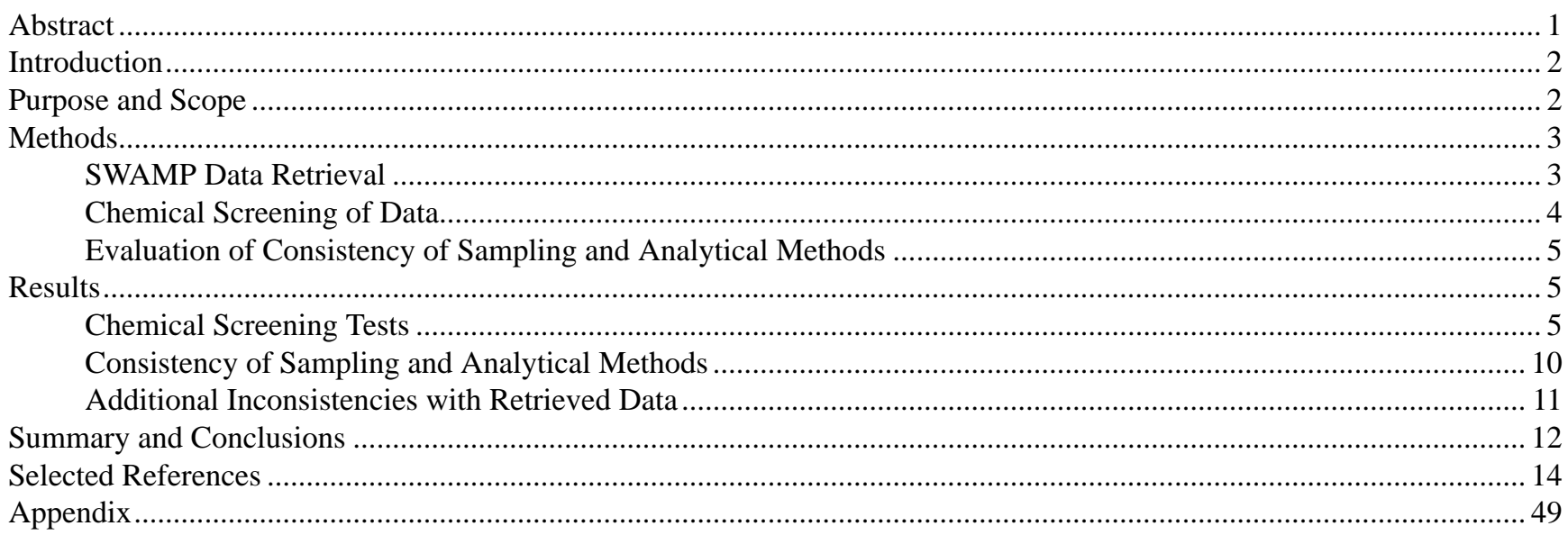

Figures

1-2. Map showing

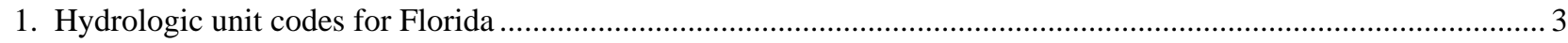

2. Boundaries of surface-water basins in Florida, and site numbers of selected SWAMP stations

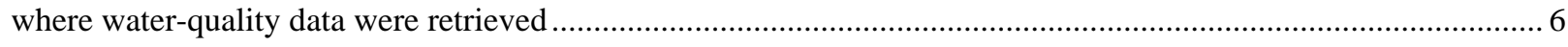

3-6. Boxplots showing the:

3. Ratio of dissolved solids to specific conductance for water samples collected at SWAMP stations ...................... 7

4. Ratio of cations to specific conductance for water samples collected at SWAMP stations .................................. 8

5. Ratio of anions to specific conductance for water samples collected at SWAMP stations ...................................... 8

6. Charge-balance error for water samples collected at SWAMP stations ............................................................

\section{Tables}

1. List of chemical constituents and physical and chemical characteristics retrieved from STORET for selected SWAMP stations.....

2. List of SWAMP sites grouped by basin (hydrologic subregion code) for which water-quality data were retrieved, site numbers, and site information

3. Number of stations sampled at each SWAMP site, total number of samples collected at each site by

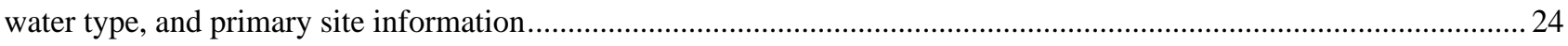

4. Number of surface-water-quality samples collected at each site in the St. Marks River Basin ...................................... 31

5. Number of chemical screening tests that were performed for surface-water-quality data from selected SWAMP sites, and the period of record for water-quality samples collected from each site .........................................3. 38

6. Summary statistics for chemical screening tests of water-quality data from selected SWAMP sites ............................ 42

7. Number of samples from selected SWAMP sites with $\mathrm{pH}$ and specific-conductance data flagged for anomalously low or high values

8. Summary of selected responses from agencies collecting surface-water-quality data to questionnaire on quality control/quality assurance procedures and information on flow measurements at SWAMP sites 
Conversion Factors, Abbreviations, and Acronyms

\begin{tabular}{rll}
\hline Multiply & By & To obtain \\
\hline meter $(\mathrm{m})$ & 3.28 & foot \\
kilometer $(\mathrm{km})$ & 0.62 & mile \\
\hline
\end{tabular}

Specific conductance is given in microsiemens per centimeter at 25 degrees Celsius $\left(\mu \mathrm{S} / \mathrm{cm}\right.$ at $\left.25{ }^{\circ} \mathrm{C}\right)$.

Concentrations of chemical constituents in water are given either in milligrams per liter $(\mathrm{mg} / \mathrm{L})$ or micrograms per liter $(\mu \mathrm{g} / \mathrm{L})$.

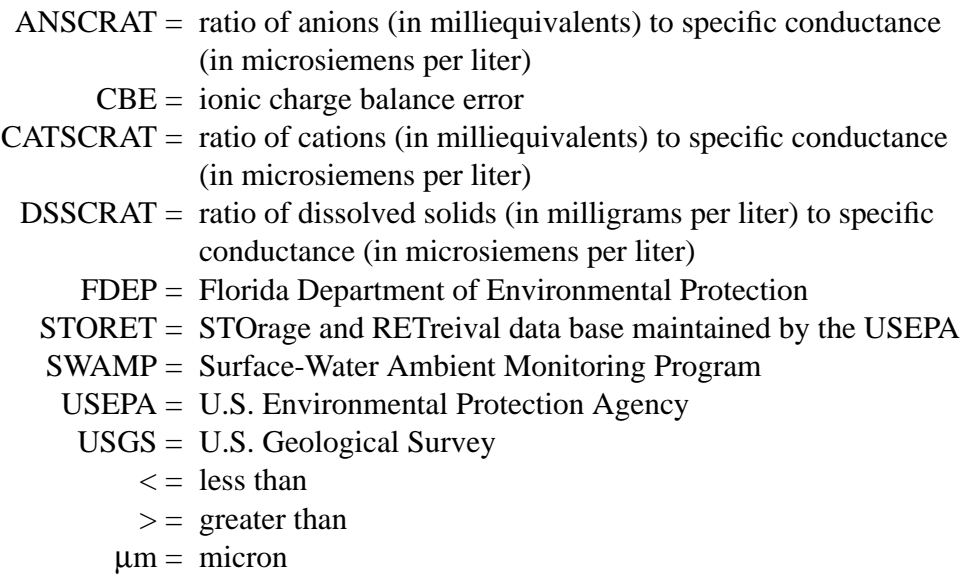




\title{
Evaluation of Chemical Data from Selected Sites in the Surface-Water Ambient Monitoring Program (SWAMP) in Florida
}

\author{
By Brian G. Katz and Jerilyn J. Collins
}

\section{Abstract}

A cooperative study between the Florida Department of Environmental Protection (FDEP) and the U.S. Geological Survey was conducted to assess the integrity of selected water-quality data collected at 150 sites in the FDEP Surface-Water Ambient Monitoring Program (SWAMP) in Florida. The assessment included determining the consistency of the water-quality data collected statewide, including commonality of monitoring procedures and analytes, screening of the gross validity of a chemical analysis, and quality assurance and quality control (QA/QC) procedures. Four tests were used to screen data at selected SWAMP sites to estimate the gross validity of selected chemical data: (1) the ratio of dissolved solids (in milligrams per liter) to specific conductance (in microsiemens per centimeter); (2) the ratio of total cations (in milliequivalents per liter) multiplied by 100 to specific conductance (in microsiemens per centimeter); (3) the ratio of total anions (in milliequivalents per liter) multiplied by 100 to specific conductance (in microsiemens per centimeter); and (4) the ionic charge-balance error. Although the results of the four screening tests indicate that the chemical data generally are quite reliable, the extremely small number of samples (less than 5 percent of the total number of samples) with sufficient chemical information to run the tests may not provide a representative indication of the analytical accuracy of all laboratories in the program. In addition to the four screening tests, unusually low or high values were flagged for field and laboratory $\mathrm{pH}$ (less than 4.0 and greater than 9.0) and specific conductance (less than 10 and greater than 10,000 microsiemens per centimeter). The numbers of flagged data were less than 1 percent of the 19,937 water samples with $\mathrm{pH}$ values and less than 0.6 percent of the 16,553 water samples with specific conductance values.

Thirty-four agencies responded to a detailed questionnaire that was sent to more than 60 agencies involved in the collection and analysis of surface-water-quality data for SWAMP. The purpose of the survey was to evaluate quality assurance methods and consistency of methods statewide. Information was compiled and summarized on monitoring network design, data review and upload procedures, laboratory and field sampling methods, and data practices. Currently, most agencies that responded to the survey follow FDEPapproved QA/QC protocol for sampling and have quality assurance practices for recording and reporting data. Also, most agencies responded that calibration procedures were followed in the laboratory for analysis of data, but no responses were given about the specific procedures. Approximately 50 percent of the respondents indicated that laboratory analysis methods have changed over time. 
With so many laboratories involved in analyzing samples for SWAMP, it is difficult to compare water quality from one site to another due to different reporting conventions for chemical constituents and different analytical methods over time. Most agencies responded that calibration methods are followed in the field, but no specific details were provided. Grab samples are the most common method of collection.

Other data screening procedures are necessary to further evaluate the validity of chemical data collected at SWAMP sites. High variability in the concentration of targeted constituents may signal analytical problems, but more likely changes in concentration are related to hydrologic conditions. This underscores the need for accurate measurements of discharge, lake stage, tidal stage at the time of sampling so that changes in constituent concentrations can be properly evaluated and fluxes (loads) of nutrients or metals, for example, can be calculated and compared over time.

\section{INTRODUCTION}

The Surface-Water Ambient Monitoring Program (SWAMP) in Florida is composed of more than 40 Federal, State, and local agencies that collect water samples at more than 4,500 sites. The Florida Department of Environmental Protection (FDEP) established a network, in 1992, of approximately 430 fixed sampling stations, which consists of a subset of 285 sites from SWAMP (streams, lakes, and estuaries), to determine if surface-water quality is changing over time and to target waterbodies with degrading water quality. This trend network is hereafter referred to as the SWAMP network. Agencies in the program have used different procedures to collect and preserve water samples. Also, water samples have been analyzed by numerous laboratories during the program. Analytical methodologies, detection limits, and reporting conventions have not always been consistent among laboratories and have likely changed over time. Water-quality data from SWAMP are stored in the U.S. Environmental Protection Agency (USEPA) STORET (STOrage and RETrieval) data base and typically are not reviewed for (1) consistency of analytes over time at a given site or among sites,
(2) quality assurance procedures (such as use of reference samples, analysis of replicate samples), or (3) the validity of the chemical analysis for each water sample.

One of the main goals of the SWAMP network in Florida is to provide technically-sound information on water quality in Florida in a cost-effective manner. Other objectives of the program are to (1) establish a permanent statewide network of sites that can be used to evaluate trends in the quality of surface water, (2) compare the quality of surface water from one basin to another, and (3) relate any differences in water quality to environmental variables, such as the predominant type of land-use in a basin, hydrology, geology, streamflow, interactions with ground water, and other basin characteristics. To be able to address these goals, the chemical validity of existing waterquality data should be assessed so that statistically significant trends can be determined or detected for selected chemical constituents. If trends are present, then factors affecting those trends can be evaluated.

\section{Purpose and Scope}

The purpose of this report is to evaluate the integrity of existing water-quality data and to provide information that will help to improve the quality of SWAMP data collected at fixed-site stations. Completion of these tasks includes evaluating the consistency of the data statewide in terms of commonality of monitoring procedures and analytes, screening of the gross validity of each analysis, and quality assurance and quality control procedures. This information is essential before decisions are made for future monitoring programs that include analysis of the data for spatial, temporal, and analyte considerations.

Chemical data from a subset of 150 sites were retrieved and reviewed from the approximately 430 fixed-sampling stations in the statewide SWAMP network. This subset of sites was used for the evaluation because the short duration of the study did not provide a sufficient amount of time for retrieval and analysis of water-quality data from all sites. The sites selected for retrieval are believed to be representative of the entire SWAMP network and were chosen to be evenly distributed geographically throughout the major basins of the State. 


\section{METHODS}

SWAMP sites were grouped by location in hydrologic subregions of the State. Hydrologic Unit Maps were developed by the U.S. Geological Survey (USGS) (Seaber and others, 1984). These hydrologic units in Florida, which are shown in figure 1, include subregions and their subdivisions of accounting units and cataloging units that represent distinct hydrologic basins. The 53 hydrologic unit codes in Florida correspond to distinct surface water drainage basins and have been used to help delineate the FDEP's ecosystem management area boundaries.

\section{SWAMP Data Retrieval}

Approximately 80 chemical constituents and water-quality characteristics (table 1) were selected for retrieval for the 150 sites from the EPA STORET data base (where most water-quality data collected by SWAMP reside). Chemical data were retrieved from STORET by the FDEP (P. Hansard, FDEP, oral commun., 1997), reformatted and entered into a statistical analysis package by the USGS for each SWAMP site. Programs were written to evaluate the gross chemical validity of the water-quality data collected by SWAMP and to statistically summarize selected water-quality constituents by surface-water drainage basin.

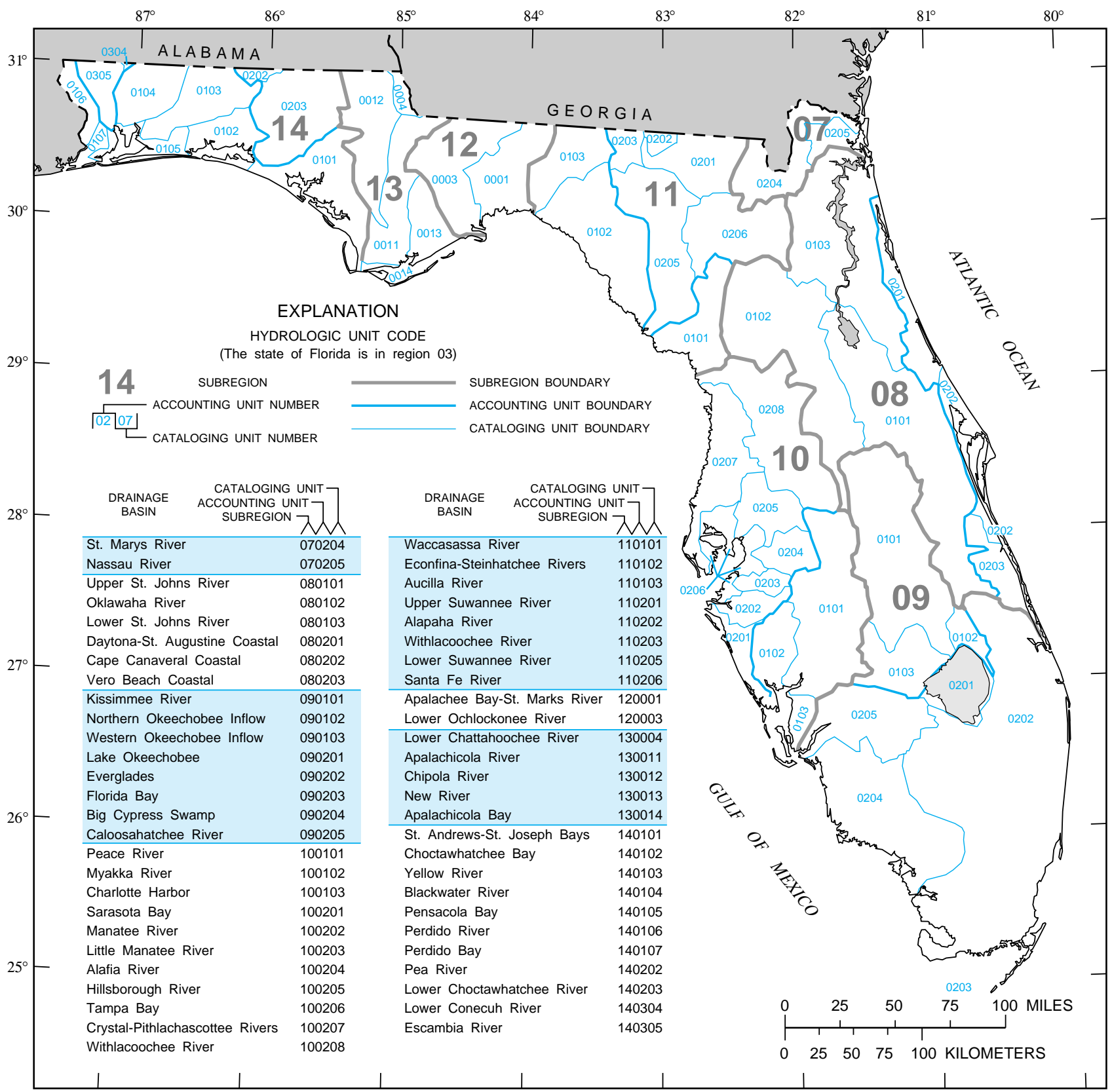

Figure 1. Hydrologic unit codes for Florida. 
When preliminary retrievals of chemical data were made from STORET for selected sites, it was observed that water samples were often collected at several additional stations at or near a main station (in most cases, each site has a designated primary station). A SWAMP site is composed of one primary sampling station or a group of nonprimary sampling stations. In some instances, the additional stations sampled may have the same locational information (latitude and longitude) as the primary station but have different station identification and/or a different station name. To ensure that all water-quality data for a station were included, data were retrieved from STORET from an area that included the primary station and all sites within a 500-m radius of the primary station. Originally a $5-\mathrm{km}$ radius was used for retrievals from STORET (Ceric and others, 1996); however, too much extraneous data were retrieved. Therefore, surfacewater-quality data presented in this report are from a SWAMP site that in most cases includes the primary sampling station, but may include water-quality data from several other nearby sampling (nonprimary) stations. For each SWAMP site, the number of analyses were tabulated for each primary station and for one or more other sites, if sampled.

In addition to retrieving water-quality data for the 150 sites, all surface-water-quality data were retrieved from STORET for the St. Marks River Basin, which is shown in subregion 12 (accounting unit 00 , cataloging unit 01 ) in figure 1 . These data were retrieved to coincide with an ongoing ecosystem management assessment of the St. Marks River Basin. Approximately 4,600 samples were collected from more than 270 sites in the basin.

\section{Chemical Screening of Data}

Where sufficient chemical data were available for a water sample from a surface-water site, four screening tests were used to evaluate the gross validity of chemical data (Hem, 1985):

(1) Ionic charge-balance error (CBE). When all the major cations (such as $\mathrm{Ca}^{2+}, \mathrm{Mg}^{2+}, \mathrm{Na}^{+}, \mathrm{K}^{+}$) and anions (such as $\mathrm{Cl}^{-}, \mathrm{SO}_{4}{ }^{2-}$, and $\mathrm{HCO}_{3}^{-}$) have been analyzed carefully, the sum of cations in equivalents should equal the sum of anions in equivalents. For waters in which the sum of cations plus anions is approximately 250 to $1,000 \mathrm{mg} / \mathrm{L}$, the difference between the two sums should typically not exceed 1 or 2 percent of the sum of cations and anions. For very dilute waters, such as rainfall or low-ionic strength (low dissolved solids) surface water, a larger charge balance error can be expected, typically \pm 10 percent but it can be as high as \pm 30 percent for samples with dissolved-solids concentrations less than $100 \mathrm{mg} / \mathrm{L}$. Dissolved solids include charged and uncharged chemical species that are operationally defined as material that passes through a $0.45-\mu \mathrm{m}$ filter. For waters with dissolved-solids concentrations much greater than $1,000 \mathrm{mg} / \mathrm{L}$, the test of CBE only evaluates the accuracy of the constituents that have large concentrations. The CBE will have a positive value when the sum of cations exceeds the sum of anions, and have a negative value when the sum of anions is greater than the sum of cations.

(2) Ratio of dissolved-solids concentrations (in milligrams per liter) to specific conductance (in microsiemens per centimeter), DSSCRAT, generally ranges from 0.55 to 0.75 for waters with dissolved-solids concentrations less than about 3,000 mg/L. Surface waters with high bicarbonate or chloride concentrations tend to have ratios near the low end of the range; whereas waters high in sulfate may have DSSCRAT values near 0.75 or higher (Hem, 1985). Waters that contain high concentrations of silica or that are saturated with respect to gypsum may have DSSCRAT values as high as 1.0. For very dilute waters, the relation between dissolved solids and specific conductance becomes less well defined (Hem, 1985).

(3) The ratio of total cations (in milliequivalents per liter) multiplied by 100 to specific conductance (in microsiemens per centimeter), CATSCRAT, should be about $1.0, \pm 0.2$. Hem (1985) notes that this relation is not exact, but tends to be less variable than the relation between specific conductance and dissolved solids (in milligrams per liter).

(4) The ratio of total anions (in milliequivalents per liter) multiplied by 100 to specific conductance (in microsiemens per centimeter), ANSCRAT, should be close to $1.0, \pm 0.2$. Also, this relation may not be exact but does provide an indication of the relative accuracy of anion analyses and would reveal major transcription errors in specific-conductance values.

Other basic screening procedures were used to evaluate transcription errors and/or analytical errors. These procedures included flagging $\mathrm{pH}$ values that were reported as less than 4.0 and greater than 9.0 and specific conductance values that were reported as less than 10 and greater than $10,000 \mu \mathrm{S} / \mathrm{cm}$. Gross-validity tests and screening programs are summarized by subregion. 


\section{Evaluation of Consistency of Sampling and Analytical Methods}

A detailed questionnaire was prepared and sent to more than 60 agencies involved in collecting surface-water-quality data for SWAMP (see appendix). The purpose of this survey was to gather information and to evaluate quality assurance methods and consistency of methods statewide. Information was compiled and summarized on monitoring network design, laboratory and field sampling methods, data review, and procedures of loading data into STORET, and data practices. Additional information obtained from the questionnaire included: (1) consistency of sampling methods, analytical methods, and detection limits for chemical constituents, (2) the use of quality assurance samples such as reference samples, replicates, and blanks, (3) the frequency of manual and (or) computer assisted review of analytical results, (4) the ability to request reruns from the laboratory if chemical data are questionable or fail certain criteria, (5) identification of basins where chemical and hydrologic data are insufficient for analysis of water-quality trends, and (6) the accessiblity of the water-quality data to waterresource managers and other interested stakeholders.

\section{RESULTS}

The locations of selected SWAMP sites where water-quality data were retrieved are shown in figure 2 with respect to hydrologic subregion and basin number. There were an insufficient number of data for sites in two subregions; therefore, sites in subregion 07 (St. Mary's River and Nassau River Basins) were combined with those in subregion 08 (St. Johns River) and sites in subregion 13 (Appalachicola River Basin) were combined with basins in subregion 14 (Escambia River to St. Andrews-St. Joseph Bays). Site names, station numbers, and site information are listed in table 2. SWAMP site numbers grouped by basin number in table 2 are provided for cross referencing with figure 2 .

The total number of samples collected at the selected SWAMP sites (fig. 1) are listed in table 3. Each sample refers to an entry in STORET that has an associated unique date and time. This may include field measurements or laboratory analyses, or both, for a water sample for selected analytes. The total number of samples represents the sum of samples collected at a given site for one or more water types (stream, canal, lake, estuary, or spring). Most SWAMP sites have a designated primary station (table 3); however, a site may have one or more stations sampled other than a primary station (within a $0.5-\mathrm{km}$ radius of the primary station). The total number of stations at a given site is listed by station identification number and locational information (latitude and longitude) in table 3. If a particular SWAMP site has one or more stations, the total number of samples in table 3 may not be the same as the number of samples for the designated primary station. In those cases, table 3 lists the number of samples collected at the designated primary station and the number of samples collected at one or more stations that have the same locational information (latitude and longitude) as the designated primary station. Making the situation even more complicated is the fact that the additional sampled stations may have different station identification numbers, station names, or both. The number of samples collected at selected SWAMP sites was quite variable, ranging from no data at several sites to 11,004 at site 13 in basin 1 (table 3).

In contrast to the aforementioned primary and additional stations (within a $0.5-\mathrm{km}$ radius of the primary station) sampled at a particular SWAMP site, all surface-water sites that have water-quality data in STORET for the St. Marks River Basin (basin 3, fig. 2) are listed in table 4. A total of 4,591 samples were collected from approximately 270 sites in the basin (table 4 ).

\section{Chemical Screening Tests}

Four tests were used to screen data at selected SWAMP sites to estimate the gross validity (a measure of analytical accuracy) of selected chemical data: CBE, DSSCRAT, CATSCRAT, and ANSCRAT. Only a small percentage of samples from each basin (fig. 2), typically less than 5 percent, had sufficient chemical data to run these four chemical screening tests. For example, in basin 2, out of the 218 samples collected, there were no samples that contained sufficient chemical data to perform any of the screening tests. In contrast, in basin 4, 4.1 and 4.2 percent of samples had sufficient chemical data (dissolved solids, specific conductance, and major cations) to run DSSCRAT and CATSCRAT screening tests, respectively (table 5).

The median DSSCRAT value for water samples from all basins with samples containing data for dissolved solids and specific conductance was 0.57 (table 6), which falls near the low end of the typical range of 0.55 to 0.75 for surface waters (Hem, 1985). This may result from surface waters that have chloride 


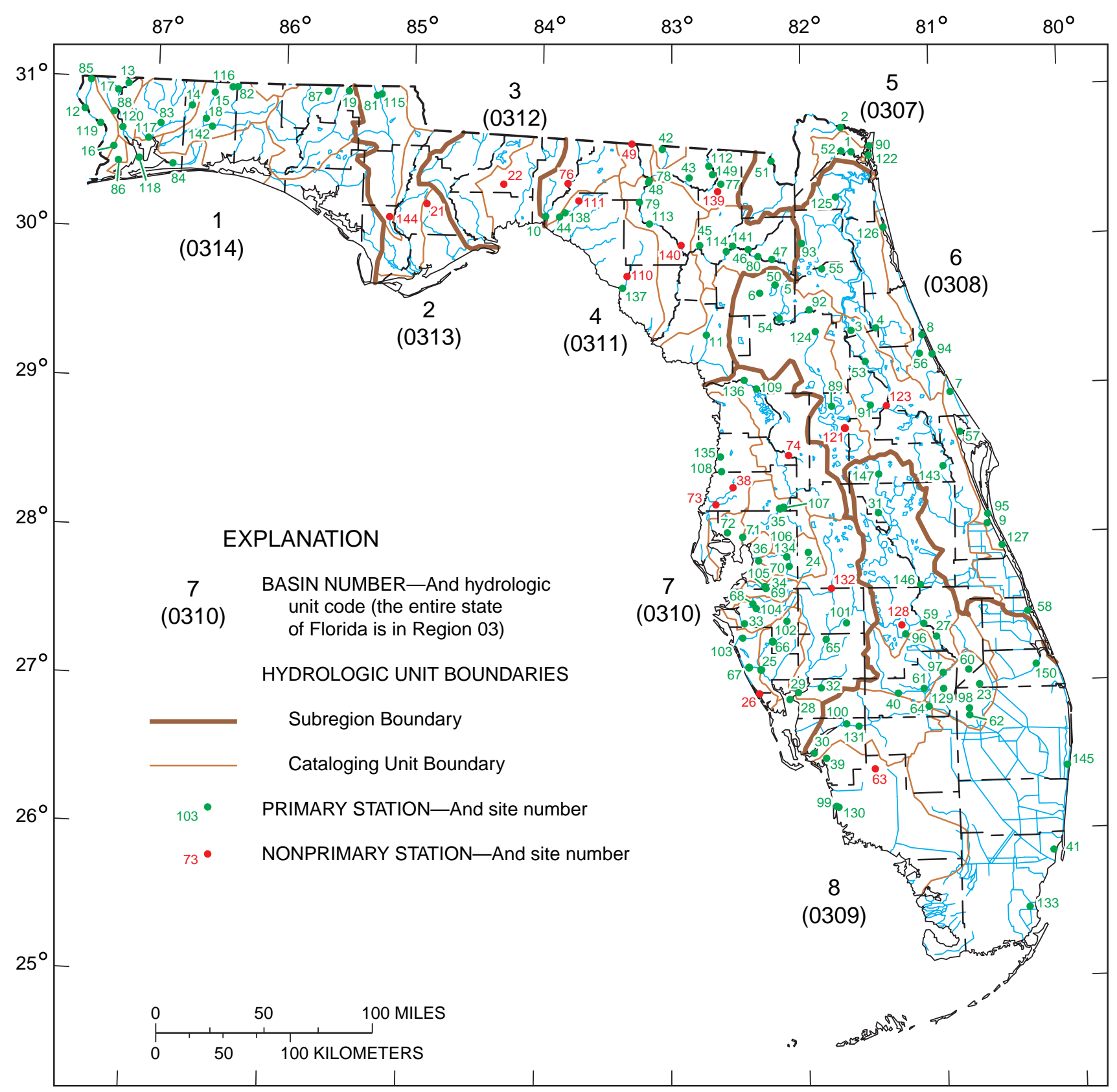

Figure 2. Boundaries of surface-water basins in Florida, and site numbers of selected SWAMP stations where waterquality data were retrieved.

or bicarbonate as their major anion (Hem, 1985). There were small differences in median DSSCRAT by basin, with values of 0.55 for water samples from basin 5 and 0.62 for samples from basin 1. However, large differences were found for mean DSSCRAT values by basin, with values ranging from 0.57 for water samples from basin 3 to 5.45 for basin 8 . The anomalously high DSSCRAT values indicate that errors likely were made in reporting specific conductance, or possibly errors were made in the measurement or reporting of these two parameters by the laboratory.
The distribution of DSSCRAT values is shown in a box and whisker plot for each basin (fig. 3) For all basins, 80 percent of the DSSCRAT values (data that fall within the 10th and 90th percentiles) fall within the 0.55 to 0.75 range, indicating the likelihood that specific conductance and dissolved solids determinations were reliable and very few reporting or transcription errors occurred. DSSCRAT values tend to be more useful for screening data at a particular site over time because a rather tightly defined relation can be defined between dissolved solids and specific conduc- 


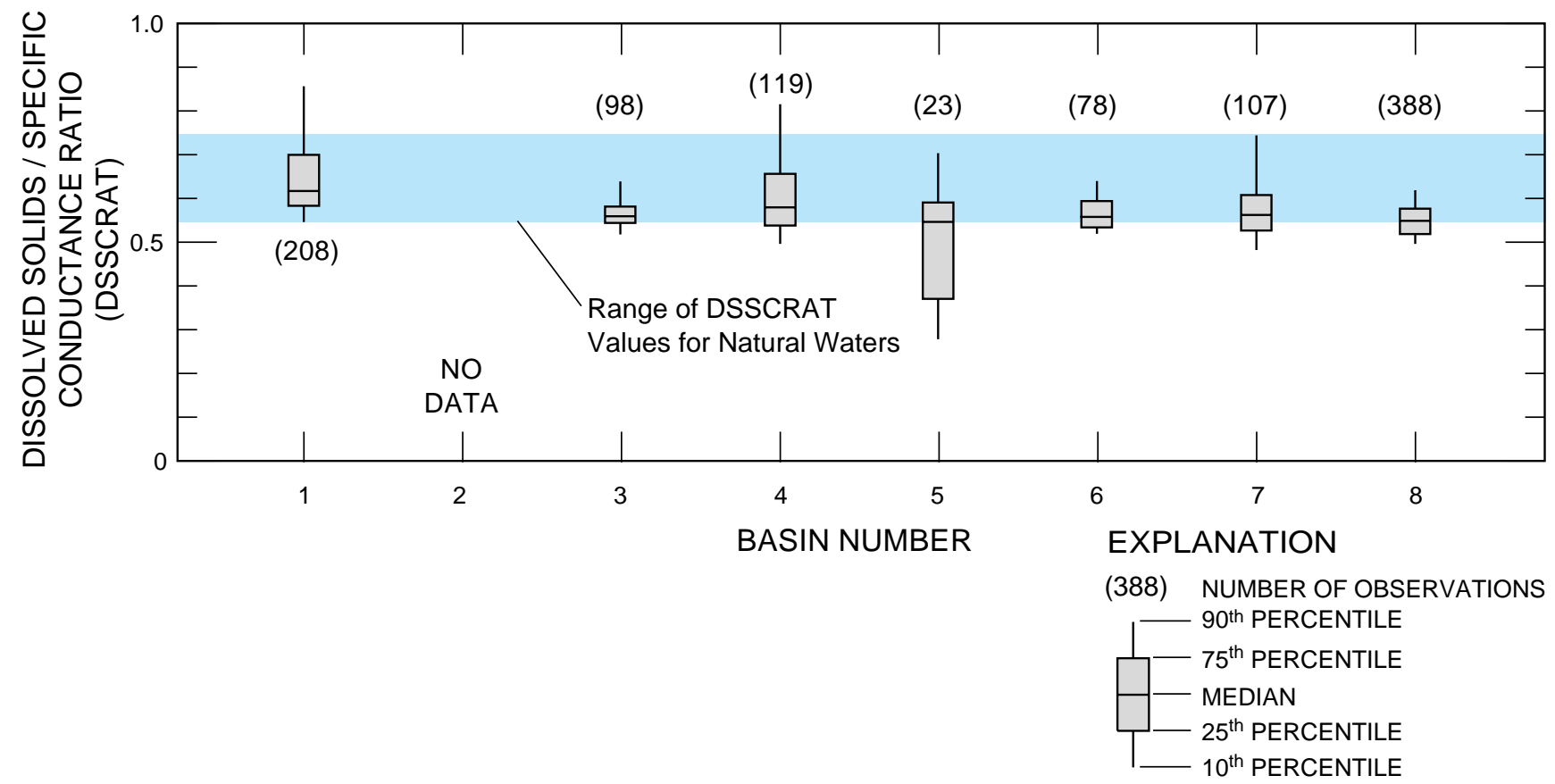

Figure 3. Ratio of dissolved solids to specific conductance for water samples collected at SWAMP stations.

tance with repeated samples at that site. The use of DSSCRAT is not as precise a screening tool for waters that are in contact with different lithologies and have varying proportions of ground-water inflow, such as in Florida.

Median values of CATSCRAT (0.98) and ANSCRAT (0.86) for water samples from all basins were well within the range of acceptable error for these ratios, $1.0 \pm 0.2$ (table 6). Cations $\left(\mathrm{Ca}^{2+}, \mathrm{Mg}^{2+}, \mathrm{Na}^{+}\right.$, $\mathrm{K}^{+}, \mathrm{NH}_{4}^{+}$) were much more commonly analyzed in surface-water samples than major anions $\left(\mathrm{Cl}^{-}, \mathrm{HCO}^{-}\right.$, $\mathrm{F}^{-}, \mathrm{SO}_{4}{ }^{2-}$ ), thus 1,528 CATSCRAT analyses were done compared to 146 for ANSCRAT. As was the case with DSSCRAT values, there were large differences in mean CATSCRAT values by basin, ranging from 0.85 to 8.76 ; the high mean values most likely resulting from either incorrect values reported for the sum of cations or values of specific conductance that were measured or reported too low. In contrast, mean values of ANSCRAT did not vary as much from one basin to another, ranging from 0.76 to 0.99 . This range is well within the allowable range of error. The distribution of CATSCRAT and ANSCRAT values are shown in boxplots for each basin in figures 4 and 5. A very tight distribution of CATSCRAT values is observed for surface-water samples from sites in basins 1, 3, 6, 7, and 8 ; whereas wider ranges in values are noted for surface-water samples from basins 4 and 5 (fig. 4). In basin 5, the wide range in CATSCRAT values may result from surface water containing high dissolvedsolids concentrations (Hem, 1985), and a greater chance for analytical error. Sufficient chemical data were present to calculate ANSCRAT values for basins $1,3,4$, and 8 , and fairly tight distributions of ANSCRAT values were observed (fig. 5).

For all basins, the number of samples that had sufficient chemical data for major cations and anions that allowed the calculation of the ionic chargebalance error was equal to 146 ; the number of samples where ANSCRAT values were calculated (table 6). The median CBE value for water samples from all basins is 5.98 percent, indicating that analytical accuracy is quite good overall. Median values do vary considerably by basin, with values ranging from 4.34 percent for samples from basin 8 to 13.4 percent for samples from basin 6 (table 6).

The paucity of negative values for CBE indicates that analyses for one or more anionic species (for example organic anions) are probably being omitted. Water samples from blackwater streams that contain elevated concentrations of tannic acid commonly have organic anions that form complexes with metals, and the usual analytical procedures do not measure these 


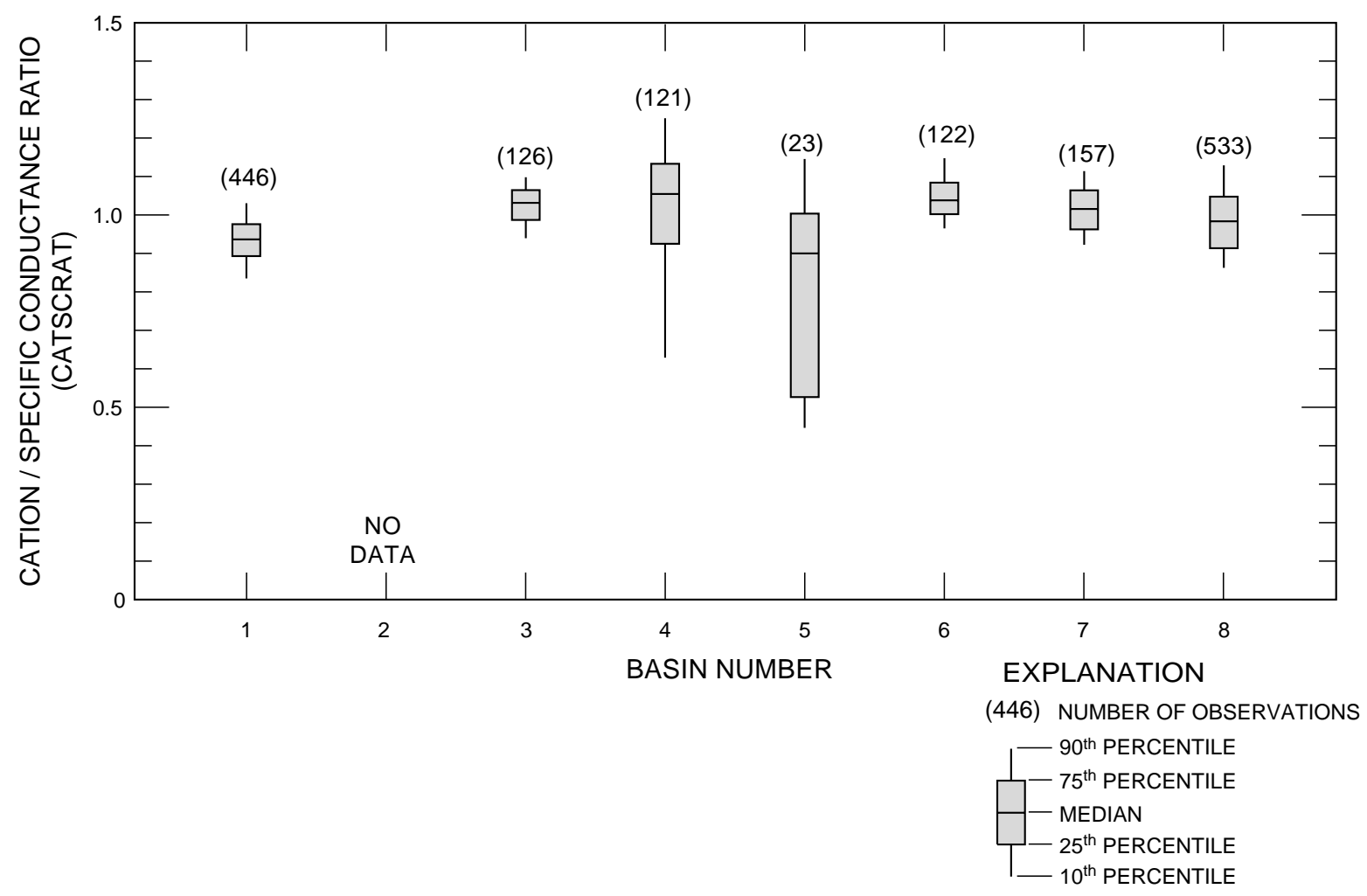

Figure 4. Ratio of cations to specific conductance for water samples collected at SWAMP stations.

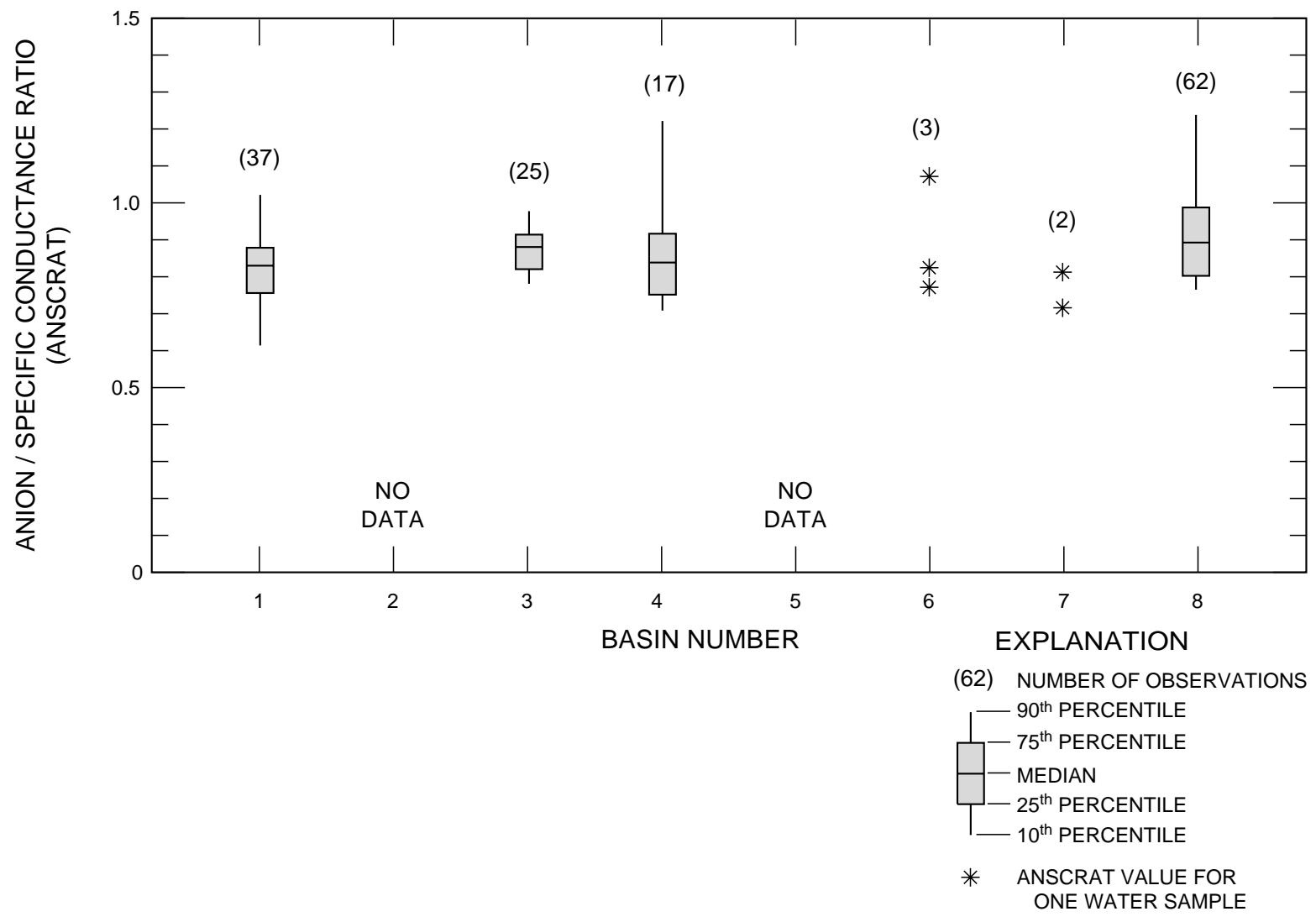

Figure 5. Ratio of anions to specific conductance for water samples collected at SWAMP stations. 
organic anions (Hem, 1985). In these waters, there tends to be a positive bias in the CBE indicating that these organic anions have not been analyzed and, therefore, are not included in the sum of anions for the charge-balance calculation. Another factor that may contribute to positive bias in these samples is related to the methods of sample collection. If water samples are not filtered in the field and samples for cation analysis are acidified, suspended particles may be brought into solution and elevated concentrations of cations may result. Due to limited resources, no attempts were made to separate out filtered versus unfiltered water samples in the retrieved data.

Values of CBE were plotted against sample collection date (fig. 6) to determine if there was any bias over time in analytical procedures for determination of major ions. Sufficient chemical data to calculate $\mathrm{CBE}$ values were available for only two samples prior to 1974, but a positive bias in CBE values can be seen throughout the entire period of record, 1960 to 1990 (fig. 6). Also worth noting is that three samples from basin 4, which includes the Suwannee River Basin in Florida, have negative values for CBE. These values, which fall outside of the typical CBE range for acceptable analytical results, may result from the occurrence of very dilute waters in this basin. Commonly, a larger percentage error is found for surface waters where the total of anions and cations is less than about 5.0 milliequivalents per liter (Hem, 1985).

There are several important limitations that need to be noted regarding the use of these four screening tests for assessing validity of chemical analyses.

First, if a laboratory consistently provides poor results, the analytical results could still be precise but not accurate. This may not be indicated by large chargebalance errors; compensating errors can go unnoticed and large errors in the determination of minor constituents may not be detected. Second, the only effective way to determine the accuracy of laboratory analytical data is by evaluating the laboratory's quality assurance

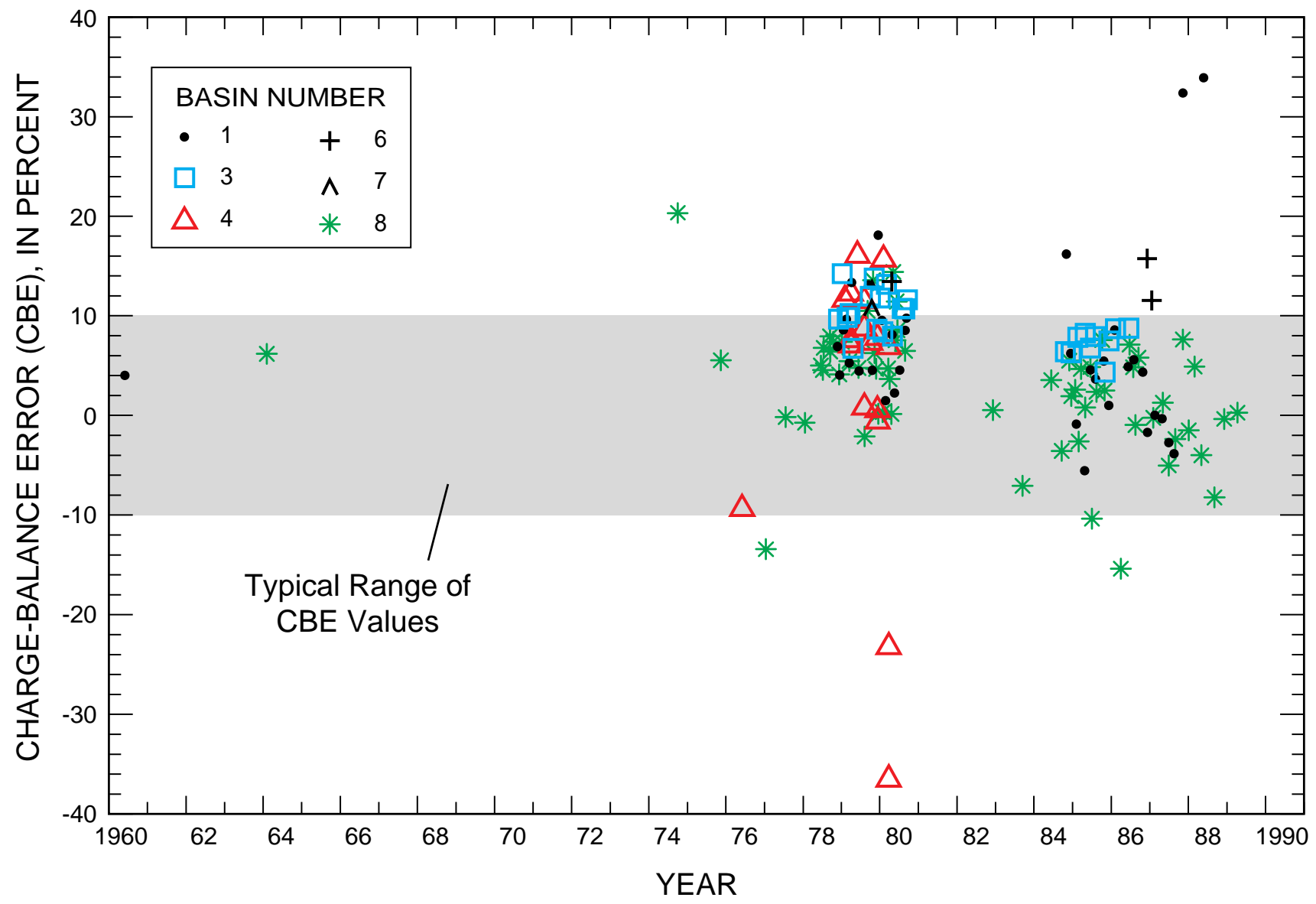

Figure 6. Charge-balance error for water samples collected at SWAMP stations. 
records. Obtaining laboratory quality assurance and quality control (QA/QC) information for all SWAMP sites would be a monumental task, given the number of laboratories involved in SWAMP over time. Third, the extremely small number of samples (less than 5 percent of the total) with sufficient chemical information to run the four screening tests may not provide a representative indication of the analytical accuracy of all laboratories in the program. Obviously, other data screening procedures are necessary to further evaluate the validity of chemical data.

In addition to the four screening tests, unusual data values were flagged for field and laboratory $\mathrm{pH}$ $(<4.0$ and $>9.0)$ and specific conductance $(<10$ and $>10,000 \mathrm{uS} / \mathrm{cm})$. For the entire retrieved data set, there were very few samples that had flagged values of $\mathrm{pH}$ or specific conductance (table 7). For the 34,559 total number of water samples from the 150 retrieved SWAMP sites, there was a total of $19,937 \mathrm{pH}$ values and 16,553 specific conductance values. Of the 19,937 water samples with $\mathrm{pH}$ values, only 76 ( 0.4 percent) and 9 ( 0.03 percent) samples for field and laboratory $\mathrm{pH}$, respectively, had values less than 4 or greater than 9. Of the 16,553 water samples with specific conductance values, only 103 ( 0.6 percent) and 82 ( 0.5 percent) samples had field and laboratory specific conductance values, respectively, that were less than 10 or greater than $10,000 \mu \mathrm{S} / \mathrm{cm}$ (table 7).

For future screening of chemical data from selected SWAMP sites, it would be beneficial to determine if there are unusual concentration relations among major cations or anions. For example, analyses could be screened for higher concentrations of potassium than sodium, or higher measured dissolvedsolids concentrations than the sum of cations and anions in milligrams per liter. A most effective way of screening for anomalous concentrations is to plot the data against time. High variability could signal analytical problems, but more likely indicate that hydrologic conditions are changing or are variable. This underscores the need for accurate measurements of discharge, lake stage, and gage height at the time of sampling so that changes in constituent concentrations can be properly evaluated so that fluxes (loads) of nutrients or metals can be calculated and compared over time.

\section{Consistency of Sampling and Analytical Methods}

A total of 34 agencies responded to the questionnaire (app. I) designed to evaluate quality assurance methods and consistency of methods statewide. Summarized in this section are the responses to questions from the survey regarding four main areas: (1) QA/QC protocols regarding accuracy, precision, and representativeness of collected samples, (2) method of collection of data in the field, and (3) laboratory analytical methods, and (4) collection of flow data (table 8).

The majority of those agencies responding to the questionnaire indicated that steps were taken to insure accuracy, precision, comparability, and representativeness of water samples collected at SWAMP stations. Twenty-seven agencies (out of 34 total) responded that they follow the FDEP-approved QA/QC protocol for sampling. Also, a high number of agencies also responded positively to having quality assurance practices for recording data (28) and for reporting data (23). However, when asked what quality assurance practices were used for recording and reporting data, the majority of agencies (30) did not respond. There was also a low rate of response to questions regarding qualification of data at the station and sample level and for making provisions for informing users of the quality of the data.

In terms of data collection methods in the field, 30 respondents indicated that they measure field parameters, but there were no responses to questions about the list of parameters, methods of analysis, and reporting units. Most agencies (28) responded that calibration methods are followed in the field, but none responded to the question about what these methods actually are. Eleven and 13 agencies indicated that calibration methods are stored and recorded, respectively, but 19 agencies did not respond to the query about calibration methods being stored and recorded. Respondents indicated that most water samples are grab samples that are collected at individual points in the surface-water body. However, 10 agencies responded that their samples are depth or width-integrated and composited. When asked for information on how the samples were composited there was no response from 33 agencies. 
Concerning the issue of laboratory analytical methods, most of the respondents (26) indicated that calibration procedures were followed in the laboratory for analysis of data, but no responses were given about the specific procedures. Approximately 50 percent of the respondents indicated that laboratory analysis methods have changed over time, but almost all agencies (32 out of 34) did not respond to the question asking if steps were taken to insure that the changes in laboratory methods did not impair data comparability. Most agencies (24-25) were able to provide a list of analytes with detection limits and laboratory reporting units for analytical methods.

Although the collection of flow data at SWAMP sites is not specifically a QA/QC issue, the importance of flow data in conjunction with water-quality samples takes on considerable importance now in terms of the estimation of total maximum daily loads. The majority of respondents indicated that gage height (22) and discharge (18) were not measured during collection of water-quality samples. Also, 17 agencies indicated that tidal stages were not being recorded for the collection of estuary samples.

The importance of collecting hydrologic data (streamflow, lake stage, freshwater inflow to estuaries, tidal stages) for interpreting and evaluating loads and trends in water quality of lakes, streams, and estuaries cannot be overstated. Nutrient loads and trends cannot be determined without hydrologic information. Seasonal variations of water chemistry in streams typically are related to changes in streamflow. For example, the concentration of nitrate in water samples from the Suwannee River, along the middle reach of the river from Dowling Park to Branford, Fla., is inversely related to discharge (Hornsby and Mattson, 1996). During low-flow conditions, nitrate concentrations in the Suwannee River are considerably higher than during high-flow conditions. This finding, along with the absence of any major stream inputs to the middle Suwannee River, indicates that ground water contributes most of the nitrogen load to the Suwannee River along this middle reach (Pittman and others, 1997). Also, climatic variables that cause changes in lake stage and salinity changes in estuaries affect the concentration of chemical species in these water bodies. In most areas of Florida, the degree of interaction between surface-water and ground-water systems also controls nutrient loading to and the fate of contaminants in surface water bodies.
The combination of information on discharge at selected SWAMP stations along with reliable and chemically valid data on nutrients and other constituents of ecological concern, is critical for evaluating variability in concentrations of these constituents over time. If concentrations of a particular analyte vary dramatically over time or show an increase or decrease over the period of record, without hydrologic data, it cannot be determined if these changes result primarily from variable hydrologic conditions, such as discharge fluctuations. At stations where surface-water flow data and chemical data exist, plots of constituent concentrations against discharge would provide important information about their relation over time and seasonal variations. This type of comparison would provide a greater measure of uncertainty when calculating a water-quality index for a stream or lake, or when estimating total maximum daily loads for a designated stream segment.

Choquette and others (1997) discuss how changes in streamflow affect water quality and the importance of knowing trends in streamflow to be able to evaluate concurrent trends in stream- water quality in the SWAMP network. They found that 71 sites in the trend network are located at active USGS gaging stations, and an additional 60 sites are located near active USGS gaging stations (as of 1996). Choquette and others (1997) also present methods that can be used to estimate instantaneous or daily mean streamflow at the SWAMP network trend sites from USGS gaged sites that coincide with water-quality sampling. The selection of an optimal method is dependent on several factors including the availability of discharge information near the SWAMP site, the needed accuracy of the estimates, the range of discharge values at the site, the correlation between target discharges at the gaged and ungaged sites, and the characteristics of the surface-water basin (Choquette and others, 1997).

\section{Additional Inconsistencies with Retrieved Data}

Several problems were observed when locational information for SWAMP sites (retrieved latitude and longitude information for sampled stations) were plotted for each site using a geographical information system (GIS) program. A number of problems that occurred fairly frequently included: (1) the site or station did not plot near a body of water when compared to USGS 1:24,000 topographic maps (using the 
latitude and longitude data that were retrieved from STORET), (2) the site or station plotted near a body of water but not on it, (3) primary and nonprimary stations plotted on the incorrect body of water, (4) some sites with identical location information had different station identification numbers and or station names. For example, sites 5 and 50 have identical latitude and longitude information and station numbers (table 3); however, in STORET site 5 is named Hatchet Creek near Gainesville and site 50 is named Spruce Creek near Samsula. Another example is site 52 where there are one or more sites with identical latitude and longitude, but have station names indicating two different water bodies.

Missing data were another commonly encountered problem with retrievals from STORET. There were no water-quality data retrieved from STORET for seven SWAMP sites: 20, 21, 22, 26, 37, 75, and 148 (table 3 , fig. 1). It is assumed that water-quality data were not entered for these sites; however, without intensive investigation, other data-base problems cannot be ruled out. For example, retrievals would not be possible if incorrect latitude and longitude data were stored in STORET. Also, if values for latitude and longitude did not match those stored in STORET a complete set of data would not be retrieved.

Other water-quality data missing from some of the retrievals included samples collected by other agencies, such as the USGS. Water-quality data for most NASQAN stations or other USGS surface-waterquality sites were not present in the retrieved data. For example, the USGS NASQAN station name, Escambia River near Century, appears in the retrieved data set, but there are no water-quality data included. These data should have been transferred to STORET from the USGS data base. These data are either not in STORET or were not retrieved by the FDEP. Time did not permit further checking to determine if water-quality data from other NASQAN stations from other parts of the State were not in the data base.

\section{SUMMARY AND CONCLUSIONS}

A cooperative study between the Florida Department of Environmental Protection (FDEP) and the U.S. Geological Survey has evaluated the integrity of selected water-quality data collected at 150 sites in the Surface-Water Ambient Monitoring Program
(SWAMP) in Florida. The assessment included determining the consistency of the data statewide in terms of commonality of monitoring procedures and analytes, screening of the gross validity of chemical analyses, and quality assurance and quality control procedures. Knowledge about the integrity of historical chemical data is essential to be able to determine trends in surface-water quality over time, to target waterbodies of degrading water quality, and to make recommendations for improving future monitoring network designs that include spatial, temporal, and analyte considerations.

Chemical data from a subset of 150 sites were retrieved from the U.S. Environmental Protection Agency (USEPA) STORET (STOrage and RETrieval) data base and reviewed from the approximately 430 fixed-sampling stations (streams, lakes, and estuaries) in the statewide SWAMP network that was established in 1992 by the FDEP. SWAMP is composed of more 40 Federal, State, and local agencies that collect water samples at more than 4,500 sites. The sites selected for retrieval of surface-water-quality data are probably representative of sites in the complete SWAMP network and were chosen to be evenly distributed geographically in the major surface-water basins of the State.

Four tests were used to screen surface-waterquality data from selected SWAMP sites to estimate the gross validity (a measure of analytical accuracy) of selected chemical data. These tests included: (1) the ratio of dissolved solids (in milligrams per liter) to specific conductance (in microsiemens per centimeter), DSSCRAT; (2) the ratio of total cations (in milliequivalents per liter) multiplied by 100 to specific conductance (in microsiemens per centimeter), CATSCRAT; (3) the ratio of total anions (in milliequivalents per liter) multiplied by 100 to specific conductance (in microsiemens per centimeter), ANSCRAT; and (4) the ionic charge-balance error, CBE. Although the results of the four screening tests indicate that the chemical data generally are quite reliable, the extremely small number of samples (less than 5 percent of the total) with sufficient chemical information to run the tests may not provide a representative indication of the performance of all laboratories involved in the program. With so many laboratories involved in SWAMP, it is difficult to compare water-quality data from one site to another due to different reporting conventions for 
chemical constituents and different analytical methods over time. In future monitoring programs, a reduced number of laboratories would enhance consistency in analytical methods and reporting conventions.

In addition to the four screening tests, unusually high or low values were flagged for field and laboratory $\mathrm{pH}$ (less than 4.0 and greater than 9.0) and specific conductance (less than 10 and greater than 10,000 $\mu \mathrm{S} / \mathrm{cm})$. Of the 19,937 water samples with retrieved $\mathrm{pH}$ values from the 150 SWAMP sites, only $76(0.4$ percent) and 9 (0.03 percent) samples had field and laboratory $\mathrm{pH}$ values, respectively, that were less than 4 or greater than 9 . Of the 16,553 water samples with specific conductance values, only 103 (0.6 percent) and 82 ( 0.5 percent) samples had field and laboratory specific conductance values, respectively, that were less than 10 or greater than $10,000 \mu \mathrm{S} / \mathrm{cm}$.

A detailed questionnaire was prepared and sent to more than 60 agencies involved in collecting surface-water-quality data for SWAMP and responses were received from 34 agencies. The purpose of this survey was to evaluate quality assurance methods and consistency of field and laboratory methods statewide. Information was compiled and summarized on monitoring network design, data review and upload procedures, laboratory and field sampling methods, and data practices.

Currently, most agencies responded that they follow the FDEP-approved QA/QC protocol for sampling and have quality assurance practices for recording and reporting data. A small number of agencies responded to specific questions regarding the ability to qualify data at the station and sample level and to inform users of the quality of the data. Regarding data collection methods in the field, most respondents indicated that they measure field parameters, but there were no responses to questions about the list of parameters, methods of analysis, and reporting units. Most agencies responded that calibration methods are followed in the field, but none gave specific details. Most agencies indicated that grab samples are collected at individual points in the surface-water body. However, nearly one-third of the agencies responded that their samples are depth or width integrated and composited.

Concerning the issue of laboratory analytical methods, most of the respondents indicated that calibration procedures were followed in the laboratory for analysis of data, but no responses were given about the specific procedures. Approximately 50 percent of the respondents indicated that laboratory analysis methods have changed over time, and most agencies were able to provide a list of analytes with detection limits and laboratory reporting units for analytical methods. A more centralized approach to QA/QC issues and overall project management would result in improvements to SWAMP by enhancing the consistency of sampling and analytical methods statewide.

Although the collection of flow data at SWAMP sites is not directly a QA/QC issue, the importance of flow data in conjunction with water-quality samples takes on considerable importance, particularly now in terms of estimating total maximum daily loads. The majority of respondents indicated that gage height and discharge were not measured during collection of water-quality samples. Also, about half of the agencies responded that tidal stages were not being recorded during the collection of estuary samples.

Other data screening procedures are necessary to further evaluate the validity of chemical data collected by SWAMP. High variability in the concentration of targeted constituents could signal analytical problems, but more likely may indicate variability in hydrologic conditions. This underscores the need for accurate measurements of discharge, lake stage, gage height at the time of sampling so that changes in constituent concentrations can be properly evaluated and fluxes (loads) of nutrients or metal, for example, can be calculated and compared over time.

Seasonal variations of water chemistry in streams typically are related to changes in streamflow. Recent studies have found that the concentration of nitrate in water samples from the middle reach of the Suwannee River is inversely related to discharge. The absence of any major stream inputs to the middle Suwannee River, indicates that ground water contributes most of the nitrogen load to the middle Suwannee River, particularly during low-flow conditions. Also, climatic variables that cause changes in lake stage and salinity changes in estuaries affect the concentration of chemical species in these water bodies. Several studies have demonstrated the importance of knowing trends in streamflow to be able to evaluate concurrent trends in stream water quality.

Information obtained during this study provides a framework for improving the quality and consistency of chemical data collected statewide as part of the Surface-Water Ambient Monitoring Program. 
Any redesign of the trends network would benefit from the following procedures and considerations: (1) standardization of analytical methods and detection limits for all water samples collected from the network; (2) uniform surface-water sampling methods that include the use of QA/QC samples including reference samples, replicates, and blanks; (3) a centralized computer system for ease of data retrieval, computer-assisted review of analytical data, flags for questionable data, and ability to request reruns from laboratory when chemical screening critieria are not met; and (4) integration of hydrologic data (streamflow, lake stage, tidal stage) with water-quality data to calculate loads and to assess the degree of interaction between ground water and surface water. The resulting data base would be consistent and defensible, and could include data that can be used to compare the quality of surface water in basins from one part of the State to another and to identify and assess meaningful trends in water quality over time.

\section{SELECTED REFERENCES}

Ceric, A. Garaway, J., Sottilare, J., and Winkler, S., 1996, Florida surface water ambient monitoring program (SWAMP) sampling frequency design for trend detection: St. Johns River Water Management District Special Publication SJ96, 147 p.

Choquette, A.F., Ham, L.K., and Sepulveda, A.A., 1997, Methods for estimating streamflow and analyzing streamflow and water-quality trends for the SurfaceWater Ambient Monitoring Program (SWAMP) network in Florida: U.S. Geological Survey Open-File Report 97-352, $41 \mathrm{p}$.

Hem, J.D., 1985, Study and interpretation of the chemical characteristics of natural water ( $3 d$ ed.): U.S. Geological Survey Water-Supply Paper 2254, 263 p.

Hornsby, H.D., and Mattson, R., 1996. Surface water quality and biological monitoring network. Suwannee River Water Management District Annual Report WR-96-02, $130 \mathrm{p}$.

Pittman, J.R., Hatzell, H.H., and Oaksford, E.T., 1997, Spring contributions to water quantity and nitrate loads in the Suwannee River during base flow in July 1995: U.S. Geological Survey Water-Resources Investigations Report 97-4152, 12 p.

Rumenik, R.P., 1988, Runoff to streams in Florida: Florida Bureau of Geology Map Series 122, 1 sheet.

Rumenik, R.P., and Grubbs, J.W., 1996, Low-flow characteristics of Florida streams: U.S. Geological Survey Water-Resources Investigations Report 93-4165, 220 p.

Seaber, P.R., Kapinos, F.P., and Knapp, G.L., 1984. State hydrologic unit maps: U.S. Geological Survey OpenFile Report 84-708, 21 p. 


\section{Tables}

Tables 1-8 
Table 1. List of chemical constituents, and physical and chemical characteristics retrieved from STORET for selected SWAMP stations

[mg/L, milligrams per liter; ${ }^{\circ} \mathrm{C}$, degrees Celsius; $\mu \mathrm{g} / \mathrm{L}$, micrograms per liter; $\mu \mathrm{S} / \mathrm{cm}$ at $25^{\circ} \mathrm{C}$, microsiemens per centimeter at 25 degrees Celsius; ft, feet; ${ }^{\circ} \mathrm{F}$, degrees Fahrenheit; TU, turbidity]

\begin{tabular}{|c|c|}
\hline Parameter name (reporting units) & STORET code \\
\hline Alkalinity, total $\left(\mathrm{mg} / \mathrm{L}\right.$ as $\left.\mathrm{CaCO}_{3}\right)$ & 410 \\
\hline Aluminum, total $(\mu \mathrm{g} / \mathrm{L}$ as $\mathrm{Al})$ & 1105 \\
\hline Arsenic, dissolved ( $\mu \mathrm{g} / \mathrm{L}$ as As) & 1000 \\
\hline Arsenic, total $(\mu \mathrm{g} / \mathrm{L}$ as $\mathrm{As})$ & 1002 \\
\hline Barium, dissolved $(\mu \mathrm{g} / \mathrm{L}$ as $\mathrm{Ba})$ & 1005 \\
\hline Bicarbonate $\left(\mathrm{mg} / \mathrm{L}\right.$ as $\left.\mathrm{HCO}_{3}\right)$ & 440 \\
\hline Boron, total $(\mu \mathrm{g} / \mathrm{L}$ as $\mathrm{B})$ & 1022 \\
\hline Cadmium, dissolved $(\mu \mathrm{g} / \mathrm{L}$ as $\mathrm{Cd})$ & 1025 \\
\hline Cadmium, total $(\mu \mathrm{g} / \mathrm{L}$ as $\mathrm{Cd})$ & 1027 \\
\hline Calcium, dissolved (mg/L as $\mathrm{Ca})$ & 915 \\
\hline Calcium, total (mg/L as $\mathrm{Ca})$ & 916 \\
\hline Carbon, dissolved organic (mg/L as C) & 681 \\
\hline Carbon, total (mg/L as $\mathrm{C})$ & 690 \\
\hline Carbon, total organic $(\mathrm{mg} / \mathrm{L}$ as $\mathrm{C})$ & 680 \\
\hline Chloride, total in water & 940 \\
\hline Chlorophyll-A (mg/L trichromatic uncorrected) & 32210 \\
\hline Chromium, dissolved ( $\mu \mathrm{g} / \mathrm{L}$ as $\mathrm{Cr})$ & 1030 \\
\hline Chromium, total $(\mu \mathrm{g} / \mathrm{L}$ as $\mathrm{Cr})$ & 1034 \\
\hline Cobalt, dissolved ( $\mu \mathrm{g} / \mathrm{L}$ as $\mathrm{Co})$ & 1035 \\
\hline Cobalt, total $(\mu \mathrm{g} / \mathrm{L}$ as $\mathrm{Co})$ & 1037 \\
\hline Color (platinum-cobalt units) & 80 \\
\hline Copper, dissolved $(\mu \mathrm{g} / \mathrm{L}$ as $\mathrm{Cu})$ & 1040 \\
\hline Copper, total $(\mu \mathrm{g} / \mathrm{L}$ as $\mathrm{Cu})$ & 1042 \\
\hline Depth of pond or reservoir (ft) & 72025 \\
\hline Fecal coliform (colonies per $100 \mathrm{~mL}$ ) & 31616 \\
\hline Flow, stream, instantaneous & 61 \\
\hline Flow, stream, mean daily & 60 \\
\hline Fluoride, dissolved (mg/L as F) & 950 \\
\hline Iron, dissolved $(\mu \mathrm{g} / \mathrm{L}$ as $\mathrm{Fe})$ & 1046 \\
\hline Iron, total $(\mu \mathrm{g} / \mathrm{L}$ as $\mathrm{Fe})$ & 1045 \\
\hline Lead, dissolved $(\mu \mathrm{g} / \mathrm{L}$ as $\mathrm{Pb})$ & 1049 \\
\hline Lead, total $(\mu \mathrm{g} / \mathrm{L}$ as $\mathrm{Pb})$ & 1051 \\
\hline Magnesium, dissolved (mg/L as $\mathrm{Mg}$ ) & 925 \\
\hline Magnesium, total (mg/L as $\mathrm{Mg}$ ) & 927 \\
\hline Manganese, dissolved ( $\mu \mathrm{g} / \mathrm{L}$ as $\mathrm{Mn})$ & 1056 \\
\hline Manganese, total $(\mu \mathrm{g} / \mathrm{L}$ as $\mathrm{Mn})$ & 1055 \\
\hline Mercury, dissolved $(\mu \mathrm{g} / \mathrm{L}$ as $\mathrm{Hg})$ & 71890 \\
\hline Mercury, total $(\mu \mathrm{g} / \mathrm{L}$ as $\mathrm{Hg})$ & 71900 \\
\hline Nickel, dissolved $(\mu \mathrm{g} / \mathrm{L}$ as $\mathrm{Ni})$ & 1065 \\
\hline Nickel, total $(\mu \mathrm{g} / \mathrm{L}$ as Ni) & 1067 \\
\hline Nitrite plus nitrate, dissolved $(\mathrm{mg} / \mathrm{L}$ as $\mathrm{N})$ & 631 \\
\hline
\end{tabular}


Table 1. List of chemical constituents, and physical and chemical characteristics retrieved from STORET for selected SWAMP stations (Continued)

[mg/L, milligrams per liter; ${ }^{\circ} \mathrm{C}$, degrees Celsius; $\mu \mathrm{g} / \mathrm{L}$, micrograms per liter; $\mu \mathrm{S} / \mathrm{cm}$ at $25^{\circ} \mathrm{C}$, microsiemens per centimeter at 25 degrees Celsius; ft, feet; ${ }^{\circ} \mathrm{F}$, degrees Fahrenheit;

TU, turbidity]

\begin{tabular}{|c|c|}
\hline Parameter name (reporting units) & STORET code \\
\hline Nitrite plus nitrate, total (mg/L as $\mathrm{N})$ & 630 \\
\hline Nitrogen, ammonia, dissolved (mg/L as $\mathrm{N})$ & 608 \\
\hline Nitrogen, ammonia, total (mg/L as $\mathrm{N})$ & 610 \\
\hline Nitrogen, Kjeldahl, dissolved (mg/L as $\mathrm{N}$ & 623 \\
\hline Nitrogen, Kjeldahl, total, (mg/L as $\mathrm{N})$ & 625 \\
\hline Nitrogen, organic, dissolved ( $\mathrm{mg} / \mathrm{L}$ as $\mathrm{N})$ & 607 \\
\hline Nitrogen, organic, total (mg/L as $\mathrm{N})$ & 605 \\
\hline Oxygen, dissolved (mg/L) & 300 \\
\hline $\mathrm{pH}$ (standard units) & 400 \\
\hline $\mathrm{pH}$, lab (standard units) & 403 \\
\hline Phosphorus, dissolved orthophosphate ( $\mathrm{mg} / \mathrm{L}$ as $\mathrm{P}$ ) & 671 \\
\hline Phosphorus, total (mg/L as $\mathrm{P}$ ) & 665 \\
\hline Potassium, dissolved (mg/L as $\mathrm{K})$ & 935 \\
\hline Potassium, total (mg/L as $\mathrm{K})$ & 937 \\
\hline Residue, total (mg/L) & 500 \\
\hline Residue, total nonfiltrable (mg/L) & 530 \\
\hline Residue, volatile nonfiltrable (mg/L) & 535 \\
\hline Residue, total filtrable (dried at $180^{\circ} \mathrm{C}$ ) & 70300 \\
\hline Sampling station location, vertical (ft) & 3 \\
\hline Selenium, dissolved $(\mu \mathrm{g} / \mathrm{L}$ as $\mathrm{Se})$ & 1145 \\
\hline Silica, dissolved $\left(\mathrm{mg} / \mathrm{L}\right.$ as $\left.\mathrm{SiO}_{2}\right)$ & 955 \\
\hline Silver, dissolved $(\mu \mathrm{g} / \mathrm{L}$ as $\mathrm{Ag})$ & 1075 \\
\hline Silver, total $(\mu \mathrm{g} / \mathrm{L}$ as $\mathrm{Ag})$ & 1077 \\
\hline Sodium, dissolved (mg/L as $\mathrm{Na}$ ) & 930 \\
\hline Sodium, total (mg/L as $\mathrm{Na})$ & 929 \\
\hline Solids, dissolved, sum of constituents (mg/L) & 70301 \\
\hline Specific conductance $\left(\mu \mathrm{S} / \mathrm{cm}\right.$ at $\left.25^{\circ} \mathrm{C}\right)$ & 95 \\
\hline Specific conductance, field $\left(\mu \mathrm{S} / \mathrm{cm}\right.$ at $\left.25^{\circ} \mathrm{C}\right)$ & 94 \\
\hline Stage, stream $(\mathrm{ft})$ & 65 \\
\hline Strontium, dissolved ( $\mu \mathrm{g} / \mathrm{L}$ as $\mathrm{Sr})$ & 1080 \\
\hline Sulfate, total $\left(\mathrm{mg} / \mathrm{L}\right.$ as $\left.\mathrm{SO}_{4}\right)$ & 945 \\
\hline Temperature, air $\left({ }^{\circ} \mathrm{F}\right)$ & 21 \\
\hline Temperature, water $\left({ }^{\circ} \mathrm{C}\right)$ & 10 \\
\hline Temperature, water $\left({ }^{\circ} \mathrm{C}\right)$ & 11 \\
\hline Transparency, secchi disc (inches) & 77 \\
\hline Turbidity, hach turbidimeter (formazin TU) & 76 \\
\hline Zinc, dissolved ( $\mu \mathrm{g} / \mathrm{L}$ as $\mathrm{Zn})$ & 1090 \\
\hline Zinc, total $(\mu \mathrm{g} / \mathrm{L}$ as $\mathrm{Zn})$ & 1092 \\
\hline
\end{tabular}


Table 2. List of SWAMP sites grouped by basin (hydrologic subregion code) for which water-quality data were retrieved, site numbers, and site information

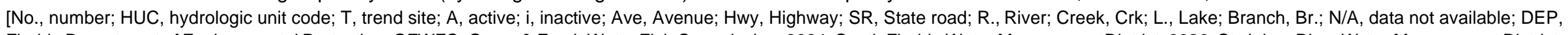

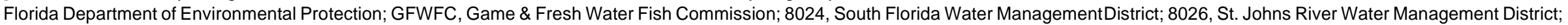
8027, Suwannee River Water Management District; BFA, Brine Fisherman's Association; 8031, Northeast DEP District]

\begin{tabular}{|c|c|c|c|c|c|c|c|c|c|c|c|c|}
\hline $\begin{array}{l}\text { Site } \\
\text { No. }\end{array}$ & Site name & $\begin{array}{c}\text { Station } \\
\text { No. }\end{array}$ & County & HUC & $\begin{array}{l}\text { Lati- } \\
\text { tude }\end{array}$ & $\begin{array}{l}\text { Longi- } \\
\text { tude }\end{array}$ & $\begin{array}{c}\text { Water } \\
\text { body } \\
\text { type }\end{array}$ & Water body & $\mathbf{T}$ & DEP ID & ID & Agency \\
\hline \multicolumn{13}{|c|}{ Basin 1} \\
\hline 12 & PERDIDO R. ABV JUNC BRUSHY CR. & 33010001 & ESCAMBIA & 3140106 & 304705 & 873400 & STREAM & PERDIDO R. & A & NW01 & 33010001 & BFA \\
\hline 13 & ESCAMBIA R. HWY 4 BRIDGE & 33020001 & ESCAMBIA & 3140305 & 305754 & 871403 & STREAM & ESCAMBIA R. & A & NW03 & 33020001 & BFA \\
\hline 14 & BLACKWATER R. AT HWY 4 NW BAKER & 33030001 & OKALOOSA & 3140104 & 305002 & 864400 & STREAM & BLACKWATER R. & $A$ & NW04 & 33030001 & BFA \\
\hline 15 & YELLOW R. HWY 2 EAST OF OAK GROVE & 33040001 & OKALOOSA & 3140103 & 305530 & 863334 & STREAM & YELLOW R. & A & NW05 & 33040001 & BFA \\
\hline 16 & 11 MILE CRK AT SR 297A BR & 33010011 & ESCAMBIA & 3140107 & 303229 & 871948 & STREAM & ELEVEN MILE CRK & A & NW19 & 33010011 & BFA \\
\hline 17 & CANOE CR HWY 29 & 33020039 & ESCAMBIA & 3140105 & 305511 & 871848 & STREAM & CANOE CRK & A & NW22 & 33020039 & BFA \\
\hline 18 & SHOAL R. AT HWY 85 & 33040031 & OKALOOSA & 3140303 & 304148 & 863417 & STREAM & SHOAL R. & $A$ & NW28 & 33040031 & BFA \\
\hline 19 & HOLMES CR HWY 2 W OF GRACEVILLE & 32020003 & JACKSON & 3140203 & 305741 & 853050 & STREAM & HOLMES CRK & $A$ & NW09 & 32020003 & DEP/205J \\
\hline 82 & POND CRK AT SR 85 W OF PAXTON & 33040008 & WALTON & 3140103 & 305800 & 862300 & STREAM & POND CRK & A & NW06 & 33040008 & BFA \\
\hline 83 & BIG COLDWATER CR HWY 191 NE MILTON & 33030005 & SANTA ROSA & 3140104 & 304227 & 865818 & STREAM & BIG COLDWATER CRK & A & NW24 & 33030005 & BFA \\
\hline 84 & EAST BAY CRK AT FL 87 & 33030025 & SANTA ROSA & 3140105 & 302627 & 865200 & STREAM & EAST BAY CRK & A & NW29 & 33030025 & BFA \\
\hline 85 & BRUSHY CRK AT NAKOMIS RD. & 33010063 & ESCAMBIA & 3140106 & 305845 & 873142 & STREAM & BRUSHY CRK & A & NW02 & 33010063 & BFA \\
\hline 86 & MARCUS CRK HWY 90 BRIDGE & 33010030 & ESCAMBIA & 3140107 & 302652 & 871724 & STREAM & MARCUS CRK & A & NW20 & 33010030 & BFA \\
\hline 87 & WRIGHTS CR HWY 2 E OF ESTO & 32020002 & HOLMES & 3140203 & 305721 & 854036 & STREAM & WRIGHTS CRK & A & NW10 & 32020002 & DEP/205J \\
\hline 88 & PINE BARREN CR HWY 29 & 33020040 & ESCAMBIA & 3140305 & 304624 & 872018 & STREAM & PINE BARRON CRK & A & NW21 & 33020040 & BFA \\
\hline 116 & HORSEHEAD CRK AT FL85 & 33040041 & OKALOOSA & 3140103 & 305754 & 862517 & STREAM & HORSEHEAD CRK & A & NW07 & 33040041 & BFA \\
\hline 117 & POND CR HWY 90 BR W MILTON & 33030019 & SANTA ROSA & 3140104 & 303621 & 870345 & STREAM & POND CRK & A & NW25 & 33030019 & $\mathrm{BFA}$ \\
\hline 118 & CARPENTERS CRK AT 9TH AVE & 33020048 & ESCAMBIA & 3140105 & 302810 & 871240 & STREAM & CARPENTERS CRK & A & NW30 & 33020048 & BFA \\
\hline 119 & PERDIDO R BARRINEAU PARK BR & 33010002 & ESCAMBIA & 3140106 & 304125 & 872625 & STREAM & PERDIDO R. & A & NW18 & 33010002 & BFA \\
\hline 120 & ESCAMBIA R. AT HWY 184 BRIDGE & 33020007 & ESCAMBIA & 3140305 & 304008 & 871600 & STREAM & ESCAMBIA R. & A & NW23 & 33020007 & BFA \\
\hline 142 & TRAMMEL CRK AT HWY 4 & 33040009 & OKALOOSA & 3140103 & 304453 & 863716 & STREAM & TRAMMEL CRK & $\mathrm{A}$ & NW27 & 33040009 & BFA \\
\hline \multicolumn{13}{|c|}{ Basin 2} \\
\hline 21 & NEW RIVER AT SR 65 & S431 & LIBERTY & 3130013 & 301311 & 845330 & STREAM & NEW R. & A & NW50 & S431 & DEP/205J \\
\hline 81 & MARSHALL CR SR2 & 31020016 & JACKSON & 3130012 & 305612 & 851745 & STREAM & MARSHALL CRK & A & NW11 & 31020016 & DEP/205J \\
\hline 115 & COWARTS CR SR2 & 31020018 & JACKSON & 3130012 & 305650 & 851530 & STREAM & COWARTS CRK & A & NW12 & 31020018 & DEP/205J \\
\hline 144 & DEAD LAKES AT SR22A & S334 & GULF & 3130012 & 300740 & 851039 & LAKE & DEAD LAKES & A & NW40 & S334 & DEP/205J \\
\hline \multicolumn{13}{|c|}{ Basin 3} \\
\hline 22 & MUNSON SLOUG & S3 & LEON & 3090202 & 302314 & 841849 & STREAM & MUNSON SLOI & $A$ & NW55 & S3 & \\
\hline
\end{tabular}

${ }^{*}$ For more detailed information on the St. Marks River Basin, see table 4. 
Table 2. List of SWAMP sites grouped by basin (hydrologic subregion code) for which water-quality data were retrieved, site numbers, and site information (Continued) [No., number; HUC, hydrologic unit code; T, trend site; A, active; i, inactive; Ave, Avenue; Hwy, Highway; SR, State road; R., River; Creek, Crk; L., Lake; Branch, Br.; N/A, data not available; DEP, Florida Department of Environmental Protection; GFWFC, Game \& Fresh Water Fish Commission; 8024, South Florida Water ManagementDistrict; 8026, St. Johns River Water Management District; 8027, Suwannee River Water Management District; BFA, Brine Fisherman's Association; 8031, Northeast DEP District]

\begin{tabular}{|c|c|c|c|c|c|c|c|c|c|c|c|c|}
\hline $\begin{array}{l}\text { Site } \\
\text { No. }\end{array}$ & Site name & $\begin{array}{c}\text { Station } \\
\text { No. }\end{array}$ & County & HUC & $\begin{array}{l}\text { Lati- } \\
\text { tude }\end{array}$ & $\begin{array}{l}\text { Longi- } \\
\text { tude }\end{array}$ & $\begin{array}{l}\text { Water } \\
\text { body } \\
\text { type }\end{array}$ & Water body & $\mathbf{T}$ & DEP ID & ID & Agency \\
\hline \multicolumn{13}{|c|}{ Basin 4} \\
\hline 10 & AUCILLA R. AT US 98, MADISON CO. & AUC100C1 & MADISON & 3110103 & 300845 & 835822 & STREAM & AUCILLA R. & A & AUC10 & AUC100C1 & $8027 \backslash 8031$ \\
\hline 11 & WACCASASSA R. AT SR 24, LEVY CO. & WAC005C1 & LEVY & 3110101 & 292121 & 824406 & STREAM & WACCASASSA R. & A & WAC00 & WAC005C1 & 8031 \\
\hline 42 & ALAPAHA R. NEAR JENNINGS FL AT C-150 & ALA010C1 & HAMILTON & 3110202 & 303553 & 830424 & STREAM & ALAPAHA R. & A & ALA010C1 & ALA010C1 & 8027/SWIM \\
\hline 43 & CAMP BRANCH AT SR-132 & CMP010C1 & HAMILTON & 3110201 & 302425 & 825154 & STREAM & CAMP BRANCH & A & CMP010C1 & CMP010C1 & 8027 \\
\hline 44 & ECONFINA R. NEAR PERRY FL & ECN010C1 & TAYLOR & 3110102 & 301015 & 834925 & STREAM & ECONFINA R. & $\mathrm{i}$ & ECN010C1 & ECN010C1 & 8027 \\
\hline 45 & ICHETUCKNEE R. 0.2 MI NORTH OF BRIDGE & $\mathrm{ICH} 010 \mathrm{C} 1$ & COLUMBIA & 3110206 & 295716 & 824703 & STREAM & ICHETUCKNEE R. & A & $\mathrm{ICH} 010 \mathrm{C} 1$ & $\mathrm{ICH} 010 \mathrm{C} 1$ & 8027 \\
\hline 46 & OLUSTEE CRK AT SR-18 & OLS010C1 & UNION & 3110206 & 295700 & 823149 & STREAM & OLUSTEE CRK & $\mathrm{i}$ & OLS010C1 & OLS010C1 & 8027 \\
\hline 47 & SAMPSON R. & SMR010C1 & BRADFORD & 3110206 & 295136 & 821347 & STREAM & SAMPSON R. & $\mathrm{i}$ & SMR010C1 & SMR010C1 & 8027 \\
\hline 48 & SUWANNEE R. AT ELLAVILLE BELOW US-90 & SUW100C1 & SUWANNEE & 3110205 & 302237 & 831049 & STREAM & SUWANNEE R. & $\mathrm{i}$ & SUW100C1 & SUW100C1 & 8027 \\
\hline 49 & WITHLACOOCHEE R. AT STATE LINE AT C- & WIT010C1 & MADISON & 3110203 & 303806 & 831842 & STREAM & WITHLACOOCHEE R. & $\mathrm{i}$ & WIT010C1 & WIT010C1 & 8027 \\
\hline 76 & AUCILLA R. US 19/27, MADISON CO. & AUC050C1 & MADISON & 3110103 & 302202 & 834809 & STREAM & AUCILLA R. & A & AUC05 & AUC050C1 & $8027 \backslash 8031$ \\
\hline 77 & DEEP CRK AT US 441 & DEP010C1 & COLUMBIA & 3110201 & 302155 & 823712 & STREAM & DEEP CRK & A & DEP010C1 & DEP010C1 & 8027 \\
\hline 78 & WITHLACOOCHEE R. ABOVE SUWANNEE R. & WIT040C1 & HAMILTON & 3110203 & 302324 & 831020 & STREAM & WITHLACOOCHEE R. & $\mathrm{i}$ & WIT040C1 & WIT040C1 & 8027 \\
\hline 79 & SUWANNEE R. AT DOWLING PARK BRIDGE & SUW120C1 & LAFAYETTE & 3110205 & 301441 & 831459 & STREAM & SUWANNEE R. & $\mathrm{i}$ & SUW120C1 & SUW120C1 & 8027 \\
\hline 80 & NEW R. NEAR WORTHINGTON SPRINGS AT C & NEW010C1 & BRADFORD & 3110206 & 295535 & 822440 & STREAM & NEW R. & A & NEW010C1 & NEW010C1 & 8027 \\
\hline 110 & STEINHATCHEE R. ABOVE STEINHATCHEE & STN031C1 & DIXIE & 3110102 & 294449 & 832032 & STREAM & STEINHATCHEE R. & $\mathrm{i}$ & STN031C1 & STN031C1 & 8027 \\
\hline 111 & ECONFINA R. AT US 19/27, TAYLOR CO. & ECN005C1 & TAYLOR & 3110103 & 301504 & 834304 & STREAM & ECONFINA R. & A & ECNOO & ECN005C1 & 8031 \\
\hline 112 & HUNTER CRK AT C-135 OR NEAR BELMONT & HNT010C1 & HAMILTON & 3110201 & 302909 & 824245 & STREAM & HUNTER CRK & A & HNT010C1 & HNT010C1 & 8027 \\
\hline 113 & SUWANNEE R. AT LURAVILLE FL & SUW130C1 & LAFAYETTE & 3110205 & 300556 & 831019 & STREAM & SUWANNEE R. & $\mathrm{i}$ & SUW130C1 & SUW130C1 & 8027 \\
\hline 114 & SANTA FE R. NEAR BROOKER AT SR-231 & SFR020C1 & BRADFORD & 3110206 & 295243 & 822012 & STREAM & SANTA FE R. & $\mathrm{i}$ & SFR020C1 & SFR020C1 & 8027 \\
\hline 137 & STEINHATCHEE R. AT STEINHATCHEE & STN040C1 & DIXIE & 3110102 & 294004 & 832240 & STREAM & STEINHATCHEE R. & $\mathrm{i}$ & STN040C1 & STN040C1 & 8027 \\
\hline 138 & ECONFINA R. AT US 98, TAYLOR CO. & ECN015C1 & TAYLOR & 3110103 & 300831 & 835200 & STREAM & ECONFINA R. & A & ECN01 & ECN015C1 & 8031 \\
\hline 139 & ROBINSON BR AT C-246 OR NR SUWANNEE & ROB010C1 & COLUMBIA & 3110201 & 301856 & 823841 & STREAM & ROBINSON BRANCH & A & $\mathrm{ROB} 010 \mathrm{C} 1$ & ROB010C1 & 8027 \\
\hline 140 & SUWANNEE R. AT BRANFORD & SUW140C1 & SUWANNEE & 3110205 & 295720 & 825540 & STREAM & SUWANNEE R. & $\mathrm{i}$ & SUW140C1 & SUW140C1 & 8027 \\
\hline 141 & SANTA FE R. AT OLENO ST PARK & SFR040C1 & COLUMBIA & 3110206 & 295451 & 823448 & STREAM & SANTA FE R. & $\mathrm{i}$ & SFR040C1 & SFR040C1 & 8027 \\
\hline 149 & ROARING CRK AT C-135 & ROR010C1 & HAMILTON & 3110201 & 302544 & 824105 & STREAM & ROARING CRK & A & ROR010C1 & ROR010C1 & 8027 \\
\hline \multicolumn{13}{|c|}{ Basin 5} \\
\hline 1 & NASSAU RIV US 17 & 19020002 & NASSAU & 3070205 & 303428 & 813632 & STREAM & NASSAU R. & A & SJ1 & 19020002 & 8026 \\
\hline 2 & ST MARYS R AT GA LINE US 17 & 19010001 & NASSAU & 3070204 & 304416 & 814114 & STREAM & ST. MARYS R. & A & SJ3 & 19010001 & $8026 \backslash 8031$ \\
\hline 51 & MARYS R. AT SR-2 & 19010006 & BAKER & 3070204 & 303115 & 821348 & STREAM & ST. MARYS R. & A & SJ4 & 19010006 & 8026 \\
\hline
\end{tabular}


Table 2. List of SWAMP sites grouped by basin (hydrologic subregion code) for which water-quality data were retrieved, site numbers, and site information (Continued) [No., number; HUC, hydrologic unit code; T, trend site; A, active; i, inactive; Ave, Avenue; Hwy, Highway; SR, State road; R., River; Creek, Crk; L., Lake; Branch, Br.; N/A, data not available; DEP, Florida Department of Environmental Protection; GFWFC, Game \& Fresh Water Fish Commission; 8024, South Florida Water ManagementDistrict; 8026, St. Johns River Water Management District; 8027, Suwannee River Water Management District; BFA, Brine Fisherman's Association; 8031, Northeast DEP District]

\begin{tabular}{|c|c|c|c|c|c|c|c|c|c|c|c|c|}
\hline $\begin{array}{l}\text { Site } \\
\text { No. }\end{array}$ & Site name & $\begin{array}{l}\text { Station } \\
\text { No. }\end{array}$ & County & HUC & $\begin{array}{l}\text { Lati- } \\
\text { tude }\end{array}$ & $\begin{array}{l}\text { Longi- } \\
\text { tude }\end{array}$ & $\begin{array}{l}\text { Water } \\
\text { body } \\
\text { type }\end{array}$ & Water body & $\mathbf{T}$ & DEP ID & ID & Agency \\
\hline 52 & NASSAU R. NEAR ITALIA & $\mathrm{NRI}$ & NASSAU & 3070205 & 303453 & 814109 & STREAM & NASSAU R. & A & SJ2 & NRI & 8026 \\
\hline 90 & AMELIA R. (ICW) at CM 28, NASSAU CO. & 19020005 & NASSAU & 3070205 & 303648 & 812800 & STREAM & AMELIA R. & A & UNK1 & 19020005 & 8031 \\
\hline 122 & AMELIA R. (ICW) at CM 1, NASSAU CO. & 19020013 & NASSAU & 3070205 & 303300 & 812830 & STREAM & AMELIA R. & A & UNK2 & 19020013 & 8031 \\
\hline \multicolumn{13}{|c|}{ Basin 6} \\
\hline 3 & ST JOHNS R. CHAN MARK72 & 20030373 & PUTNAM & 3080101 & 292240 & 813743 & STREAM & ST. JOHNS R. & A & SJ5 & 20030373 & 8026 \\
\hline 4 & CRESCENT LK BY MARKER NO. 9 & 20030411 & VOLUSIA & 3080103 & 292332 & 812620 & LAKE & CRESCENT L. & A & SJ7 & 20030411 & 8026 \\
\hline 5 & HATCHET CRK NR GAINESVILLE & 02240800 & ALACHUA & 3080102 & 294115 & 821224 & STREAM & HATCHET CRK & A & SJ35 & 02240800 & 8026 \\
\hline 6 & SWEETWATER BRANCH & 1264A1 & ALACHUA & 3080102 & 293800 & 821930 & STREAM & SWEETWATER BR & $\mathrm{i}$ & SJ36 & 1264A1 & $N / A$ \\
\hline 7 & INDIAN RIV N ICW CHAN MARK 60 & 27010460 & VOLUSIA & 3080202 & 285721 & 805253 & STREAM & INDIAN R. & A & SJ50 & 27010460 & 8030 \\
\hline 8 & TOMOKA R OLD DIXIE HWY BR & 27010024 & VOLUSIA & 3080201 & 292030 & 810512 & STREAM & TOMOKA R. & A & SJ53 & 27010024 & 8026 \\
\hline 9 & INDIAN R. LAGOON CRANE CRK & $\mathrm{CC03}$ & BREVARD & 3080203 & 280407 & 803721 & STREAM & INDIAN R. LAGOON & A & A7 & $\mathrm{CCO3}$ & 8026 \\
\hline 50 & SPRUCE CRK NR SAMSULA & 2248000 & ALACHUA & 3080102 & $\mathrm{~N} / \mathrm{A}$ & N/A & STREAM & SPRUCE CRK & $\mathrm{N} / \mathrm{A}$ & $\mathrm{N} / \mathrm{A}$ & $\mathrm{N} / \mathrm{A}$ & $\mathrm{N} / \mathrm{A}$ \\
\hline 53 & ST JOHNS R. AT HWY 40 NEAR ASTOR & 20010002 & VOLUSIA & 3080101 & 291005 & 813125 & STREAM & ST. JOHNS R. & A & SJ19 & 20010002 & 802618030 \\
\hline 54 & $\begin{array}{l}\text { ORANGE L.B1 } 18 \text { B/T COW HAMMOCK \& } \\
\text { SAMSONS POND }\end{array}$ & OLK & ALACHUA & 3080102 & 292749 & 821038 & LAKE & ORANGE L. & A & SJ37 & OLK & 8026 \\
\hline 55 & GEORGES L. 200 YDS FROM W BANK & 20030400 & PUTNAM & 3080103 & 294734 & 815050 & LAKE & GEORGES L. & A & SJ9 & 20030400 & 8026 \\
\hline 56 & TOMOKA R. AT 11TH STREET BRIDGE & 27010579 & VOLUSIA & 3080201 & 291301 & 810633 & STREAM & TOMOKA R. & A & SJ54 & 27010579 & 8026 \\
\hline 57 & INDIAN R AT ICWW CM 12 NR HALOV & 27010875 & BREVARD & 3080202 & 284112 & 804847 & STREAM & INDIAN R. & A & SJ52 & 27010875 & 8026 \\
\hline 58 & UPSTREAM OF WEIR S50 ON C-25 ABOUT 3000 & C25S50 & ST. LUCIE & 3080203 & 272818 & 802012 & CANAL & C-25 CANAL & A & SO58 & C25S50 & 8024 \\
\hline 89 & HAINES CRK AT LOCK \& DAM & 2238000 & LAKE & 3080102 & $\mathrm{~N} / \mathrm{A}$ & $\mathrm{N} / \mathrm{A}$ & STREAM & HAINES CRK & N/A & $\mathrm{N} / \mathrm{A}$ & $\mathrm{N} / \mathrm{A}$ & $N / A$ \\
\hline 91 & BLACKWATER CRK AT HWY 44A & 20010455 & LAKE & 3080101 & 285230 & 812922 & STREAM & BLACKWATER CRK & $\mathrm{i}$ & SJ22 & 20010455 & 2 agencies \\
\hline 92 & ORANGE CRK 50 YDS. UP FROM HWY-21 & 20020404 & PUTNAM & 3080102 & 293109 & 815648 & STREAM & ORANGE CRK & A & SJ38 & 20020404 & 8026 \\
\hline 93 & KINGSLEY LK CENTER & 20030412 & CLAY & 3080103 & 295751 & 815957 & LAKE & KINGSLEY LAKE & A & SJ12 & 20030412 & 8026 \\
\hline 94 & HALIFAX R 100 FT N SL BCH MEM BR & 27010037 & VOLUSIA & 3080201 & 291242 & 810042 & STREAM & HALIFAX R. & A & SJ55 & 27010037 & 8026 \\
\hline 95 & INDIAN R. 100 YDS SOUTH OF SR 518 & 27010511 & BREVARD & 3080202 & 280752 & 803701 & STREAM & INDIAN R. & A & S051 & 27010511 & 8030 \\
\hline 121 & APOPKA BEAUCLAIR C. NR ASTATULA & 2237700 & LAKE & 3080102 & 284320 & 814106 & CANAL & APOPKA BEAUCLAIR C. & $\mathrm{i}$ & SJ47 & 2237700 & 2 agencies \\
\hline 123 & WEKIA R. PAST FIRST SHARP TURN TO RIGHT & GFCCR0196 & SEMINOLE & 3080101 & 285209 & 812202 & STREAM & WEKIVA R. & $\mathrm{i}$ & SJ23 & GFCCR0196 & GFWFC/CO. \\
\hline 124 & OKLAWAHA R. AT SR 316 & 20020012 & MARION & 3080102 & 292223 & 815406 & STREAM & OKLAWAHA R. & A & SJ40 & 20020012 & 8026 \\
\hline 125 & CEDAR CR BLANDING BLVD BR RT21 & 20030083 & DUVAL & 3080103 & 301623 & 814400 & STREAM & CEDAR CRK & A & SJ13 & 20030083 & 8026 \\
\hline 126 & TOLOMATO R. AT SPANISH LANDING & TOL & ST. JOHNS & 3080201 & 300359 & 812212 & STREAM & TOLOMATO R. & $\mathrm{i}$ & A14 & TOL & 8026 \\
\hline 127 & INDIAN R AT CM 42 NR GRANT & 27010480 & BREVARD & 3080202 & 275512 & 803056 & STREAM & INDIAN R. & A & SO49 & 27010480 & DEP \\
\hline 143 & JIM CR AT FISH HOLE RD BRIDGE & 20010521 & ORANGE & 3080101 & 282732 & 805649 & STREAM & JIM CRK & $\mathrm{i}$ & SJ31 & 20010521 & DEP \\
\hline
\end{tabular}


Table 2. List of SWAMP sites grouped by basin (hydrologic subregion code) for which water-quality data were retrieved, site numbers, and site information (Continued)

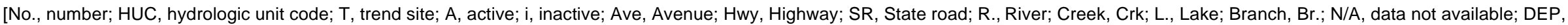

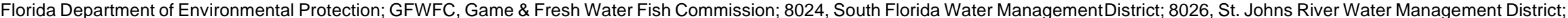
8027, Suwannee River Water Management District; BFA, Brine Fisherman's Association; 8031, Northeast DEP District]

\begin{tabular}{|c|c|c|c|c|c|c|c|c|c|c|c|c|}
\hline $\begin{array}{l}\text { Site } \\
\text { No. }\end{array}$ & Site name & $\begin{array}{l}\text { Station } \\
\text { No. }\end{array}$ & County & HUC & $\begin{array}{l}\text { Lati- } \\
\text { tude }\end{array}$ & $\begin{array}{l}\text { Longi- } \\
\text { tude }\end{array}$ & $\begin{array}{c}\text { Water } \\
\text { body } \\
\text { type }\end{array}$ & Water body & $\mathbf{T}$ & DEP ID & ID & Agency \\
\hline \multicolumn{13}{|c|}{ Basin 7} \\
\hline 24 & ALAFIA R., NORTH PRONG & 24020057 & POLK & 3100204 & 275323.4 & 815825.3 & STREAM & ALAFIA R. & A & SO21 & 24020057 & DEP \\
\hline 25 & MYAKKA R. SNOOK HAVEN DOCK & 25030408 & SARASOTA & 3100102 & 270601 & 821958 & STREAM & MYAKKA R. & A & SO26 & 25030408 & DEP \\
\hline 26 & LEMON BAY-MARKER 23 & 24010664 & CHARLOTTE & 3100201 & 265536 & 822050 & ESTUARY & LEMON BAY & A & so31 & 24010664 & DEP \\
\hline 28 & CHARLOTTE HRBR AT BLACK MRKR 1 & 25010012 & CHARLOTTE & 3100103 & 265356 & 820717 & ESTUARY & CHARLOTTE HARBOR & A & SO46 & 25010012 & DEP \\
\hline 29 & PEACE R US 41 BR & 25020001 & CHARLOTTE & 3100101 & 265642 & 820325 & STREAM & PEACE R. & A & SO47 & 25020001 & DEP \\
\hline 32 & SHELL CRK AT SR 764 BRIDGE & 25020120 & CHARLOTTE & 3100101 & 265832 & 815317 & STREAM & SHELL CRK & A & SO75 & 25020120 & DEP \\
\hline 33 & BRADEN R. AT POWERLINES & BR2 & MANATEE & 3100202 & 272446 & 822730 & STREAM & BRADEN R. & A & so86 & BR2 & COUNTY \\
\hline 34 & $\mathrm{~N} / \mathrm{A}$ & 24010013 & Hillsborough & 3100203 & 275940 & 821755 & STREAM & N/A & $\mathrm{N} / \mathrm{A}$ & $\mathrm{N} / \mathrm{A}$ & 24010013 & $N / A$ \\
\hline 35 & HILLSB. R AB CRYSTAL SPRINGS NR ZEPHYRHI & 24030013 & PASCO & 3100205 & 281102 & 821103 & STREAM & HILLSBOROUGH R. & A & so93 & 24030013 & DEP \\
\hline 36 & BULLFROG CRK AT SYMMES ROAD & 24010022 & Hillsborough & 3100206 & 275038 & 822052 & STREAM & BULLFROG CRK & A & SO102 & 24010022 & COUNTY \\
\hline 38 & PITHLACHASCOTEE R. & 24040009 & PASCO & 3090203 & 281943 & 823212 & STREAM & $\begin{array}{l}\text { PITHLACHASCOTEE } \\
\text { RI.I148 }\end{array}$ & A & SO112 & 24040009 & DEP \\
\hline 65 & PEACE R AT BR 1.5 MI W OF GARDNER & 25020459 & DESOTO & 3100101 & 271811 & 815046 & STREAM & PEACE R. & A & sO76 & 25020459 & DEP \\
\hline 66 & MYAAKKA R - CLAY GULLY AB BRIDGE ON 780 & FLO0018 & MANATEE & 3100102 & $\mathrm{~N} / \mathrm{A}$ & $\mathrm{N} / \mathrm{A}$ & STREAM & MYAAKKA R. & $\mathrm{N} / \mathrm{A}$ & $\mathrm{N} / \mathrm{A}$ & $\mathrm{N} / \mathrm{A}$ & $N / A$ \\
\hline 67 & CURRY CRK AT ALBEE FARM & FLO0099 & SARASOTA & 3100201 & $\mathrm{~N} / \mathrm{A}$ & $\mathrm{N} / \mathrm{A}$ & STREAM & CURRY CRK & $N / A$ & $\mathrm{~N} / \mathrm{A}$ & $\mathrm{N} / \mathrm{A}$ & $N / A$ \\
\hline 68 & MANATEE R-GAMBLE CK AB BR GOLF COURSE & FLO0017 & MANATEE & 3100202 & $\mathrm{~N} / \mathrm{A}$ & $\mathrm{N} / \mathrm{A}$ & STREAM & MANATEE R. & N/A & $\mathrm{N} / \mathrm{A}$ & N/A & $\mathrm{N} / \mathrm{A}$ \\
\hline 69 & LITTLE MANATEE R AT CR579 & 24010018 & Hillsborough & 3100203 & 273947 & 821804 & STREAM & LITTLE MANATEE R. & A & so91 & 24010018 & COUNTY \\
\hline 70 & ALAFIA R., SOUTH PRONG & 24020059 & Hillsborough & 3100204 & 274748.2 & 820703.3 & STREAM & ALAFIA R. & A & SO22 & 24020059 & DEP \\
\hline 71 & FLINT CR AT US 301 EAST SIDE & 24030007 & Hillsborough & 3100205 & 280510 & 821616 & STREAM & FLINT CRK & A & so95 & 24030007 & COUNTY \\
\hline 72 & ROCKY CRK AT WATERS AVE & 24040152 & Hillsborough & 3100206 & 280132 & 823451 & STREAM & ROCKY CRK & A & SO103 & 24040152 & COUNTY \\
\hline 73 & ANCLOTE R. AT SR54 & FLO0096 & PASCO & 3100207 & $\mathrm{~N} / \mathrm{A}$ & $\mathrm{N} / \mathrm{A}$ & STREAM & ANCLOTE R. & N/A & $\mathrm{N} / \mathrm{A}$ & $\mathrm{N} / \mathrm{A}$ & $N / A$ \\
\hline 74 & $\mathrm{~N} / \mathrm{A}$ & $\mathrm{N} / \mathrm{A}$ & $\mathrm{N} / \mathrm{A}$ & $\mathrm{N} / \mathrm{A}$ & $\mathrm{N} / \mathrm{A}$ & $\mathrm{N} / \mathrm{A}$ & $\mathrm{N} / \mathrm{A}$ & N/A & $\mathrm{N} / \mathrm{A}$ & $\mathrm{N} / \mathrm{A}$ & $\mathrm{N} / \mathrm{A}$ & $N / A$ \\
\hline 101 & OAK CRK/SWEETWTR/FRESHWTR REF SITE & 25020014 & HARDEE & 3100101 & 272443 & 814143 & STREAM & OAK CRK & A & SO77 & 25020014 & DEP \\
\hline 102 & MYAKKA R ABOVE OGLEBY CK & FLO0021 & MANATEE & 3100102 & $\mathrm{~N} / \mathrm{A}$ & $\mathrm{N} / \mathrm{A}$ & STREAM & MYAKKA R. & N/A & $\mathrm{N} / \mathrm{A}$ & N/A & N/A \\
\hline 103 & MAIN "A" CANAL AT BAHIA VISTA & FLO0100 & SARASOTA & 3100201 & $\mathrm{~N} / \mathrm{A}$ & $\mathrm{N} / \mathrm{A}$ & CANAL & $\mathrm{N} / \mathrm{A}$ & N/A & $\mathrm{N} / \mathrm{A}$ & $\mathrm{N} / \mathrm{A}$ & $N / A$ \\
\hline 104 & MANATEE R. RYE BRIDGE & UM1 & MANATEE & 3100202 & 273051 & 822202 & STREAM & MANATEE R. & A & SO88 & UM1 & COUNTY \\
\hline 105 & LITTLE MANATEE R., SOUTH FORK & 24010017 & Hillsborough & 3100203 & 273857.7 & 821740 & STREAM & LITTLE MANATEE R. & A & so92 & 24010017 & DEP \\
\hline 106 & S PRNG ALAFIA R UPSTR CNFL N PRN & 24020019 & Hillsborough & 3100204 & 275152 & 820812 & STREAM & ALAFIA R. & A & $\mathrm{sO} 23$ & 24020019 & COUNTY \\
\hline 107 & HILLS R- ITCHEPACKASASSA CK AB BLACKWTR & FLO0014 & PASCO & 3100205 & $\mathrm{~N} / \mathrm{A}$ & $\mathrm{N} / \mathrm{A}$ & STREAM & HILLSBOROUGH R. & $\mathrm{N} / \mathrm{A}$ & $\mathrm{N} / \mathrm{A}$ & $N / A$ & $N / A$ \\
\hline 108 & HUNTER LAKE & STA0053 & HERNANDO & 3100207 & $\mathrm{~N} / \mathrm{A}$ & $\mathrm{N} / \mathrm{A}$ & LAKE & HUNTER LAKE & $\mathrm{N} / \mathrm{A}$ & $\mathrm{N} / \mathrm{A}$ & $\mathrm{N} / \mathrm{A}$ & $N / A$ \\
\hline 109 & WITHLACOOCHEE R. AT STOKES FERRY & FLO0090 & CITRUS & 3100208 & $\mathrm{~N} / \mathrm{A}$ & $\mathrm{N} / \mathrm{A}$ & STREAM & WITHLACOOCHEE R. & N/A & $\mathrm{N} / \mathrm{A}$ & $\mathrm{N} / \mathrm{A}$ & $\mathrm{N} / \mathrm{A}$ \\
\hline
\end{tabular}


Table 2. List of SWAMP sites grouped by basin (hydrologic subregion code) for which water-quality data were retrieved, site numbers, and site information (Continued)

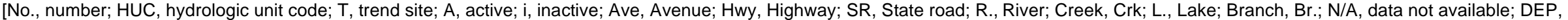

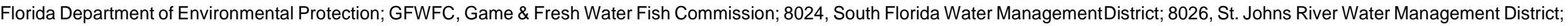
8027, Suwannee River Water Management District; BFA, Brine Fisherman's Association; 8031, Northeast DEP District]

\begin{tabular}{|c|c|c|c|c|c|c|c|c|c|c|c|c|}
\hline $\begin{array}{l}\text { Site } \\
\text { No. }\end{array}$ & Site name & $\begin{array}{l}\text { Station } \\
\text { No. }\end{array}$ & County & HUC & $\begin{array}{l}\text { Lati- } \\
\text { tude }\end{array}$ & $\begin{array}{l}\text { Longi- } \\
\text { tude }\end{array}$ & $\begin{array}{l}\text { Water } \\
\text { body } \\
\text { type }\end{array}$ & Water body & $\mathbf{T}$ & DEP ID & ID & Agency \\
\hline 132 & AT COUNTY LINE ROAD NO. 664 HARDEE CO. & $\begin{array}{r}\mathrm{PC} \\
\text { CANAL78 }\end{array}$ & POLK & 3100101 & 273837.2 & 814812 & CANAL & $\mathrm{N} / \mathrm{A}$ & A & SO78 & $\begin{array}{c}\text { PC } \\
\text { CANAL78 }\end{array}$ & COUNTY \\
\hline 134 & N PRONG ALAFIA R UPSTRM CNFL S P & 24020008 & Hillsborough & 3100204 & 275152 & 820812 & STREAM & ALAFIA R. & A & SO24 & 24020008 & COUNTY \\
\hline 135 & WEEKI WACHEE R. AT ROGERS PARK & FLO0098 & HERNANDO & 3100207 & $N / A$ & $\mathrm{~N} / \mathrm{A}$ & STREAM & WEEKI WACHEE R. & $\mathrm{N} / \mathrm{A}$ & $\mathrm{N} / \mathrm{A}$ & $\mathrm{N} / \mathrm{A}$ & $\mathrm{N} / \mathrm{A}$ \\
\hline 136 & BLUE RUN & FLO0091 & MARION & 3100208 & $N / A$ & $\mathrm{~N} / \mathrm{A}$ & STREAM & BLUE RUN & $\mathrm{N} / \mathrm{A}$ & $\mathrm{N} / \mathrm{A}$ & $\mathrm{N} / \mathrm{A}$ & $\mathrm{N} / \mathrm{A}$ \\
\hline \multicolumn{13}{|c|}{ Basin 8} \\
\hline 23 & L.OKEE-CNTRL, 6.0 STATUTE MILES DUE WEST & L004 & MARTIN & 3090102 & 265905 & 804233 & LAKE & LAKE OKEECHOBEE & A & SO05 & L004 & 8024 \\
\hline 27 & 41 MI DOWNSTREAM OF LAKE KISSIMMEE ON & S65D & Okeechobee & 3090101 & 271845 & 810120 & STREAM & KISSIMMEE R. & A & so36 & S65D & 8024 \\
\hline 30 & CALOOSAHATCHEE RIV AT REDFISH PT & 28020185 & LEE & 3090205 & 263203 & 815643 & STREAM & CALOOSAHATCHEE R. & A & so60 & 28020185 & DEP \\
\hline 31 & REEDY CRK AT S R 531 & 26010238 & OSCEOLA & 3090101 & 280900 & 812628 & STREAM & REEDY CRK & A & SO71 & 26010238 & $\mathrm{~N} / \mathrm{A}$ \\
\hline 39 & TENMILE CANAL AT US41 & 28020188 & LEE & 3090204 & 262958 & 815113 & CANAL & TENMILE CANAL & A & SO128 & 28020188 & COUNTY \\
\hline 40 & FISHEATING CRK S OF PALMDALE & 26010592 & GLADES & 3090103 & 265600 & 811856 & STREAM & FISHEATING CRK & A & SO139 & 26010592 & DEP \\
\hline 41 & LITTLE R. CANAL AT NE2 AV DAD & 28040387 & DADE & 3090202 & 255110 & 801150 & CANAL & LITTLE R. CANAL & A & SO152 & 28040387 & COUNTY \\
\hline 59 & 32 MI DOWNSTREAM OF LAKE KISSIMMEE ON & $\mathrm{S} 65 \mathrm{C}$ & Okeechobee & 3090101 & 272401 & 810657 & STREAM & KISSIMMEE R. & A & SO37 & $\mathrm{S} 65 \mathrm{C}$ & 8024 \\
\hline 60 & L.OKEE-NORTH, 1.5 STATUTE MILES AT 125 & L002 & Okeechobee & 3090102 & 270506 & 804717 & LAKE & LAKE OKEECHOBEE & A & sO07 & L002 & 8024 \\
\hline 61 & FISHEATING CRK AT SR78 & 26010582 & GLADES & 3090103 & 265746 & 810716 & STREAM & FISHEATING CRK & A & SO140 & 26010582 & DEP \\
\hline 62 & L.OKEE-SOUTH, 1.5 STATUTE MILES DUE & L007 & PALM BEACH & 3090202 & 264635 & 804719 & LAKE & LAKE OKEECHOBEE & A & SO01 & L007 & 8024 \\
\hline 63 & LAKE TRAFFORD 2 BOAT RAMP & 28030015 & COLLIER & 3090204 & 262522 & 812937 & LAKE & LAKE TRAFFORD & A & SO129 & 28030015 & DEP \\
\hline 64 & CALOOSAHATCHEE R MOORE HAVEN LOCK & 28020022 & GLADES & 3090205 & 265021 & 810507 & STREAM & $\begin{array}{l}\text { CALOSSAHATCHEE } \\
\text { R.I186 }\end{array}$ & A & sO62 & 28020022 & DEP \\
\hline 96 & OUTFLOW STRUCTURE ON S.E. SIDE OF LAKE & S68 & HIGHLANDS & 3090101 & 271944 & 811508 & $\mathrm{~N} / \mathrm{A}$ & $\mathrm{N} / \mathrm{A}$ & A & SO39 & S68 & 8024 \\
\hline 97 & INDIAN PARIRIE CANAL AT SR78 & 26010583 & GLADES & 3090103 & 270401 & 805842 & CANAL & INDIAN PRAIRIE CANAL & A & SO141 & 26010583 & DEP \\
\hline 98 & L.OKEE-SOUTH, SITE AT CLEWISTON LIGHT & L006 & PALM BEACH & 3090202 & 264922 & 804719 & LAKE & LAKE OKEECHOBEE & A & so02 & L006 & 8024 \\
\hline 99 & GORDON R. AT FL 886 & 28030047 & COLLIER & 3090204 & 261024 & 814705 & STREAM & GORDON R. & A & SO130 & 28030047 & COUNTY \\
\hline 100 & TELEGRAPH CR SR 78 BR E SR 31 IN & 28020041 & LEE & 3090205 & 264351 & 814207 & STREAM & TELEGRAPH CRK & A & SO64 & 28020041 & DEP \\
\hline 128 & LAKE ISTOKPOGA SEE MAP & ISTK7 & HIGHLANDS & 3090101 & 272335 & 811657 & LAKE & LAKE ISTOKPOGA & A & SO41 & ISTK7 & 8024 \\
\hline 129 & L.OKEE-CNTRL, SITE AT ABANDONED (RED) & L005 & GLADES & 3090202 & 265730 & 805840 & LAKE & LAKE OKEECHOBEE & A & $\mathrm{sO03}$ & L005 & 8024 \\
\hline 130 & GOLDEN GATE CANAL AT CR31 & 28030038 & COLLIER & 3090204 & 261004 & 814601 & CANAL & GOLDEN GATE C. & A & SO131 & 28030038 & COUNTY \\
\hline 131 & CALOOS R SR 78B BR & 28020006 & LEE & 3090205 & 264248 & 813636 & STREAM & CALOOSA R. & A & SO65 & 28020006 & DEP \\
\hline 133 & MANATEE R. SR 64 NR MYAKKA CITY & L4 & MANATEE & 3100202 & 272825 & 821240 & STREAM & MANATEE R. & A & SO89 & L4 & COUNTY \\
\hline 145 & UPSTREAM OF S40 ON C-15 ABOUT 400 FEET O & C15S40 & PALM BEACH & 3090202 & 262527 & 800428 & CANAL & C-15 CANAL & A & so13 & C15S40 & 8024 \\
\hline 146 & 10.5 MILES DOWNSTREAM OF L. KISSIMMEE & S65A & OSCEOLA & 3090101 & 273944 & 810803 & STREAM & KISSIMMEE R. & A & SO83 & S65A & 8024 \\
\hline
\end{tabular}


Table 2. List of SWAMP sites grouped by basin (hydrologic subregion code) for which water-quality data were retrieved, site numbers, and site information (Continued)

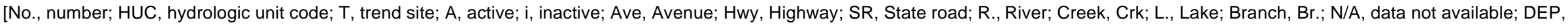

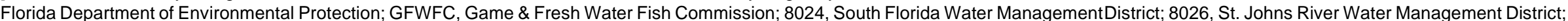
8027, Suwannee River Water Management District; BFA, Brine Fisherman's Association; 8031, Northeast DEP District]

\begin{tabular}{|c|c|c|c|c|c|c|c|c|c|c|c|c|}
\hline $\begin{array}{l}\text { Site } \\
\text { No. }\end{array}$ & Site name & $\begin{array}{c}\text { Station } \\
\text { No. }\end{array}$ & County & HUC & $\begin{array}{l}\text { Lati- } \\
\text { tude }\end{array}$ & $\begin{array}{l}\text { Longi- } \\
\text { tude }\end{array}$ & $\begin{array}{c}\text { Water } \\
\text { body } \\
\text { type }\end{array}$ & Water body & $\mathbf{T}$ & DEP ID & ID & Agency \\
\hline 147 & SHINGLE CR. AT TAFT-VINELAND RD. BRIDGE & SCC & ORANGE & 3090101 & 282435 & 812602 & STREAM & SHINGLE CRK & $A$ & SO125 & SCC & COUNTY \\
\hline 148 & HENDERSON CRK CANAL AT US41, BELLE MEA & 28039954 & COLLIER & 3090204 & 260446 & 814114 & STREAM & HENDERSON CR.I158 C. & $A$ & SO133 & 28039954 & COUNTY \\
\hline 150 & SUWANNEE R. AT FOWLER BLUFF - SUW170 & SUW240C1 & LEVY & 3110205 & 292357 & 830122 & STREAM & SUWANNEE R. & $\mathrm{i}$ & SUW240C1 & SUW240C1 & SRWMD \\
\hline
\end{tabular}

No Data Retrievable for Sites 20,37 , and 75 . 
Table 3. Number of stations sampled at each SWAMP site, total number of samples collected at each site by water type, and primary site information

\begin{tabular}{|c|c|c|c|c|c|c|c|c|c|c|c|c|c|}
\hline \multirow{2}{*}{$\begin{array}{c}\text { Site } \\
\text { No. } \\
\text { (see } \\
\text { fig. 1) }\end{array}$} & \multicolumn{2}{|c|}{$\begin{array}{l}\text { Total number of } \\
\text { stations by }\end{array}$} & \multirow{2}{*}{$\begin{array}{c}\text { Total } \\
\text { number } \\
\text { of } \\
\text { samples }\end{array}$} & \multirow{2}{*}{$\begin{array}{l}\text { Primary } \\
\text { stations }\end{array}$} & \multirow{2}{*}{$\begin{array}{c}\text { Total } \\
\text { number of } \\
\text { samples at } \\
\text { primary } \\
\text { station }\end{array}$} & \multirow{2}{*}{$\begin{array}{c}\text { Primary } \\
\text { station } \\
\text { ID } \\
\text { No. }\end{array}$} & \multirow{2}{*}{$\begin{array}{c}\text { Primary } \\
\text { station } \\
\text { Lat/ } \\
\text { Long }\end{array}$} & \multicolumn{5}{|c|}{$\begin{array}{c}\text { Total number of samples } \\
\text { by water type }\end{array}$} & \multirow{2}{*}{$\begin{array}{c}\text { Primary } \\
\text { station } \\
\text { water } \\
\text { type }\end{array}$} \\
\hline & Station ID & Lat/Long & & & & & & Stream & Canal & Lake & $\begin{array}{c}\text { Estu- } \\
\text { ary }\end{array}$ & Spring & \\
\hline \multicolumn{14}{|c|}{ Basin 1} \\
\hline \multirow[t]{2}{*}{12} & \multirow[t]{2}{*}{1} & \multirow[t]{2}{*}{1} & \multirow[t]{2}{*}{97} & \multirow[t]{2}{*}{ YES } & \multirow[t]{2}{*}{97} & \multirow[t]{2}{*}{33010001} & 304705 & \multirow[t]{2}{*}{97} & \multirow[t]{2}{*}{0} & \multirow[t]{2}{*}{0} & \multirow[t]{2}{*}{0} & 0 & stream \\
\hline & & & & & & & 873400 & & & & & & \\
\hline 13 & 9 & 6 & 11,004 & YES & & 33020001 & 305754 & 11004 & 0 & 0 & 0 & 0 & stream \\
\hline & & & & & & & 871403 & & & & & & \\
\hline 14 & 4 & 3 & 280 & YES & $202(13)$ & 33030001 & 305002 & 280 & 0 & 0 & 0 & 0 & stream \\
\hline & & & & & & & 864400 & & & & & & \\
\hline 15 & 5 & 4 & 68 & YES & $44(3)$ & 33040001 & 305530 & 68 & 0 & 0 & 0 & 0 & stream \\
\hline & & & & & & & 863334 & & & & & & \\
\hline 16 & 1 & 1 & 158 & YES & 158 & 33010011 & 303229 & 158 & 0 & 0 & 0 & 0 & stream \\
\hline & & & & & & & 871948 & & & & & & \\
\hline 17 & 3 & 2 & 104 & YES & $76(25)$ & 33020039 & 305511 & 104 & 0 & 0 & 0 & 0 & stream \\
\hline & & & & & & & 871848 & & & & & & \\
\hline 18 & 3 & 3 & 57 & YES & 30 & 33040031 & 304148 & 57 & 0 & 0 & 0 & 0 & stream \\
\hline & & & & & & & 863417 & & & & & & \\
\hline 19 & 1 & 1 & 34 & YES & 34 & 32020003 & 305741 & 34 & 0 & 0 & 0 & 0 & stream \\
\hline & & & & & & & 853050 & & & & & & \\
\hline 82 & 2 & 1 & 47 & YES & 33 & 33040008 & 305800 & 47 & 0 & 0 & 0 & 0 & stream \\
\hline & & & & & & & 862300 & & & & & & \\
\hline 83 & 3 & 2 & 141 & YES & $53(8)$ & 33030005 & 304227 & 141 & 0 & 0 & 0 & 0 & stream \\
\hline & & & & & & & 865818 & & & & & & \\
\hline 84 & 2 & 2 & 34 & YES & 18 & 33030025 & 302627 & 16 & 0 & 0 & 18 & 18 & estuary \\
\hline & & & & & & & 865200 & & & & & & \\
\hline 85 & 1 & 1 & 12 & YES & 12 & 33010063 & 305845 & 12 & 0 & 0 & 0 & 0 & stream \\
\hline & & & & & & & 873142 & & & & & & \\
\hline 86 & 2 & 2 & 86 & YES & 80 & 33010030 & 302652 & 86 & 0 & 0 & 0 & 0 & stream \\
\hline & & & & & & & 871724 & & & & & & \\
\hline 87 & 1 & 1 & 32 & YES & 32 & 32020002 & 305721 & 32 & 0 & 0 & 0 & 0 & stream \\
\hline & & & & & & & 854036 & & & & & & \\
\hline 88 & 3 & 3 & 107 & YES & 78 & 33020040 & 304624 & 107 & 0 & 0 & 0 & 0 & stream \\
\hline & & & & & & & 872018 & & & & & & \\
\hline 116 & 1 & 1 & 12 & YES & 12 & 33040041 & 305754 & 12 & 0 & 0 & 0 & 0 & stream \\
\hline & & & & & & & 862517 & & & & & & \\
\hline 117 & 2 & 2 & 87 & YES & 61 & 33030019 & 303621 & 87 & 0 & 0 & 0 & 0 & stream \\
\hline & & & & & & & 870345 & & & & & & \\
\hline 118 & 2 & & 47 & YES & 35 & 33020048 & 302810 & 47 & 0 & 0 & 0 & 0 & stream \\
\hline & & & & & & & 870746 & & & & & & \\
\hline 119 & 3 & 3 & 123 & YES & 111 & 33010002 & 304125 & 123 & 0 & 0 & 0 & 0 & stream \\
\hline & & & & & & & 872625 & & & & & & \\
\hline 120 & 3 & 2 & 220 & YES & $120(63)$ & 33020007 & 304008 & 220 & 0 & 0 & 0 & 0 & stream \\
\hline & & & & & & & 871600 & & & & & & \\
\hline
\end{tabular}


Table 3. Number of stations sampled at each SWAMP site, total number of samples collected at each site by water type, and primary site information

\begin{tabular}{|c|c|c|c|c|c|c|c|c|c|c|c|c|c|}
\hline \multirow{2}{*}{$\begin{array}{c}\text { Site } \\
\text { No. } \\
\text { (see } \\
\text { fig. 1) }\end{array}$} & \multicolumn{2}{|c|}{$\begin{array}{l}\text { Total number of } \\
\text { stations by }\end{array}$} & \multirow{2}{*}{$\begin{array}{c}\text { Total } \\
\text { number } \\
\text { of } \\
\text { samples }\end{array}$} & \multirow{2}{*}{$\begin{array}{l}\text { Primary } \\
\text { stations }\end{array}$} & \multirow{2}{*}{$\begin{array}{c}\text { Total } \\
\text { number of } \\
\text { samples at } \\
\text { primary } \\
\text { station }\end{array}$} & \multirow{2}{*}{$\begin{array}{c}\text { Primary } \\
\text { station } \\
\text { ID } \\
\text { No. }\end{array}$} & \multirow{2}{*}{$\begin{array}{c}\text { Primary } \\
\text { station } \\
\text { Lat/ } \\
\text { Long }\end{array}$} & \multicolumn{5}{|c|}{$\begin{array}{c}\text { Total number of samples } \\
\text { by water type }\end{array}$} & \multirow{2}{*}{$\begin{array}{c}\text { Primary } \\
\text { station } \\
\text { water } \\
\text { type }\end{array}$} \\
\hline & Station ID & Lat/Long & & & & & & Stream & Canal & Lake & $\begin{array}{l}\text { Estu- } \\
\text { ary }\end{array}$ & Spring & \\
\hline \multirow[t]{2}{*}{142} & 3 & 3 & 26 & YES & 19 & 33040009 & 304453 & 26 & 0 & 0 & 0 & 0 & stream \\
\hline & & & & & & & 863716 & & & & & & \\
\hline \multicolumn{14}{|c|}{ Basin 2} \\
\hline \multicolumn{14}{|c|}{$21 \quad$ NO DATA } \\
\hline \multirow[t]{2}{*}{81} & 2 & 2 & 38 & YES & 34 & 31020016 & 305612 & 38 & 0 & 0 & 0 & 0 & stream \\
\hline & & & & & & & 851745 & & & & & & \\
\hline \multirow[t]{2}{*}{115} & 2 & 2 & 41 & YES & 34 & 31020018 & 305650 & 41 & 0 & 0 & 0 & 0 & stream \\
\hline & & & & & & & 851530 & & & & & & \\
\hline 144 & 6 & 6 & 139 & NO & NO DATA & $\begin{array}{c}\text { NO } \\
\text { DATA }\end{array}$ & $\begin{array}{c}\text { NO } \\
\text { DATA }\end{array}$ & 139 & 0 & 0 & 0 & 0 & $\begin{array}{l}\text { NO } \\
\text { DATA }\end{array}$ \\
\hline \multicolumn{14}{|c|}{ Basin 3} \\
\hline \multirow[t]{2}{*}{22} & NO DATA & & & & & & 302314 & & & & & & stream \\
\hline & & & & & & & 841849 & & & & & & \\
\hline \multicolumn{14}{|c|}{ St Marks River basin sites, see table 4.} \\
\hline \multicolumn{14}{|c|}{ Basin 4} \\
\hline \multirow[t]{2}{*}{10} & 2 & 2 & 50 & YES & 8 & AUC100 & 300900 & 50 & 0 & 0 & 0 & 0 & stream \\
\hline & & & & & & $\mathrm{C} 1$ & 835753 & & & & & & \\
\hline \multirow[t]{2}{*}{11} & 3 & 2 & 37 & YES & $4(5)$ & WAC005 & 292115 & 37 & 0 & 0 & 0 & 0 & stream \\
\hline & & & & & & $\mathrm{C} 1$ & 824406 & & & & & & \\
\hline \multirow[t]{2}{*}{42} & 2 & 2 & 91 & YES & 83 & ALA010 & 303553 & 91 & 0 & 0 & 0 & 0 & stream \\
\hline & & & & & & $\mathrm{C} 1$ & 830424 & & & & & & \\
\hline \multirow[t]{2}{*}{43} & 2 & 1 & 95 & YES & $72(23)$ & CMP010 & 302425 & 95 & 0 & 0 & 0 & 0 & stream \\
\hline & & & & & & $\mathrm{C} 1$ & 825154 & & & & & & \\
\hline 44 & 3 & 3 & 75 & YES & 22 & ECN010 & 301015 & 75 & 0 & 0 & 0 & 0 & stream \\
\hline & & & & & & $\mathrm{C} 1$ & 834925 & & & & & & \\
\hline 45 & 3 & 3 & 491 & YES & 84 & ICH010 & 295716 & 99 & 0 & 0 & 0 & 0 & stream \\
\hline & & & & & & $\mathrm{C} 1$ & 824703 & & & & & & \\
\hline 46 & 3 & 3 & 101 & YES & 82 & OLS010 & 295700 & 101 & 0 & 0 & 0 & 0 & stream \\
\hline & & & & & & $\mathrm{C} 1$ & 823149 & & & & & & \\
\hline 47 & 2 & 1 & 92 & YES & $84(8)$ & SMR010 & 295136 & 95 & 0 & 0 & 0 & 0 & stream \\
\hline 48 & 1 & 1 & 83 & YES & 83 & SUW100 & 302237 & 83 & 0 & 0 & 0 & 0 & stream \\
\hline & & & & & & $\mathrm{C} 1$ & 831049 & & & & & & \\
\hline 49 & 1 & 1 & 27 & NO & NO DATA & $\begin{array}{c}\text { NO } \\
\text { DATA }\end{array}$ & $\begin{array}{c}\text { NO } \\
\text { DATA }\end{array}$ & 27 & 0 & 0 & 0 & 0 & $\begin{array}{c}\text { NO } \\
\text { DATA }\end{array}$ \\
\hline 76 & 1 & 1 & 138 & NO & NO DATA & 02204002 & $\begin{array}{c}\text { NO } \\
\text { DATA }\end{array}$ & 138 & 0 & 0 & 0 & 0 & $\begin{array}{c}\text { NO } \\
\text { DATA }\end{array}$ \\
\hline 77 & 2 & 2 & 113 & YES & 83 & DEP010 & 302155 & 113 & 0 & 0 & 0 & 0 & stream \\
\hline & & & & & & $\mathrm{C} 1$ & 823712 & & & & & & \\
\hline 78 & 4 & 4 & 159 & YES & 46 & WIT040 & 302324 & 156 & 0 & 0 & 0 & 3 & stream \\
\hline & & & & & & $\mathrm{C} 1$ & 831020 & & & & & & \\
\hline
\end{tabular}


Table 3. Number of stations sampled at each SWAMP site, total number of samples collected at each site by water type, and primary site information

\begin{tabular}{|c|c|c|c|c|c|c|c|c|c|c|c|c|c|}
\hline \multirow{2}{*}{$\begin{array}{l}\text { Site } \\
\text { No. } \\
\text { (see } \\
\text { fig. 1) }\end{array}$} & \multicolumn{2}{|c|}{$\begin{array}{l}\text { Total number of } \\
\text { stations by }\end{array}$} & \multirow{2}{*}{$\begin{array}{c}\text { Total } \\
\text { number } \\
\text { of } \\
\text { samples }\end{array}$} & \multirow{2}{*}{$\begin{array}{l}\text { Primary } \\
\text { stations }\end{array}$} & \multirow{2}{*}{$\begin{array}{c}\text { Total } \\
\text { number of } \\
\text { samples at } \\
\text { primary } \\
\text { station }\end{array}$} & \multirow{2}{*}{$\begin{array}{c}\text { Primary } \\
\text { station } \\
\text { ID } \\
\text { No. }\end{array}$} & \multirow{2}{*}{$\begin{array}{c}\text { Primary } \\
\text { station } \\
\text { Lat/ } \\
\text { Long }\end{array}$} & \multicolumn{5}{|c|}{$\begin{array}{c}\text { Total number of samples } \\
\text { by water type }\end{array}$} & \multirow{2}{*}{$\begin{array}{c}\text { Primary } \\
\text { station } \\
\text { water } \\
\text { type }\end{array}$} \\
\hline & Station ID & Lat/Long & & & & & & Stream & Canal & Lake & $\begin{array}{l}\text { Estu- } \\
\text { ary }\end{array}$ & Spring & \\
\hline 79 & 2 & 2 & 109 & YES & 83 & $\begin{array}{c}\text { SUW120 } \\
\text { C1 }\end{array}$ & $\begin{array}{l}301441 \\
831459\end{array}$ & 109 & 0 & 0 & 0 & 0 & stream \\
\hline 80 & 2 & 2 & 85 & YES & 83 & $\begin{array}{c}\text { NEW010 } \\
\text { C1 }\end{array}$ & $\begin{array}{l}295535 \\
822440\end{array}$ & 85 & 0 & 0 & 0 & 0 & stream \\
\hline 110 & 2 & 2 & 25 & NO & NO DATA & 22050066 & $\begin{array}{c}\text { NO } \\
\text { DATA }\end{array}$ & 25 & 0 & 0 & 0 & 0 & $\begin{array}{c}\text { NO } \\
\text { DATA }\end{array}$ \\
\hline 111 & 1 & 1 & 43 & NO & NO DATA & 22050026 & $\begin{array}{c}\text { NO } \\
\text { DATA }\end{array}$ & 43 & 0 & 0 & 0 & 0 & $\begin{array}{c}\text { NO } \\
\text { DATA }\end{array}$ \\
\hline 112 & 1 & 1 & 83 & YES & 83 & $\begin{array}{c}\text { HNT010 } \\
\text { C1 }\end{array}$ & $\begin{array}{l}302909 \\
824245\end{array}$ & 83 & 0 & 0 & 0 & 0 & stream \\
\hline 113 & 3 & 3 & 167 & YES & 83 & $\begin{array}{c}\text { SUW130 } \\
\text { C1 }\end{array}$ & $\begin{array}{l}300556 \\
831019\end{array}$ & 167 & 0 & 0 & 0 & 0 & stream \\
\hline 114 & 1 & 1 & 84 & YES & 84 & $\begin{array}{c}\text { SFR020 } \\
\text { C1 }\end{array}$ & $\begin{array}{l}295243 \\
822012\end{array}$ & 84 & 0 & 0 & 0 & 0 & stream \\
\hline 137 & 1 & 1 & 39 & YES & 39 & $\begin{array}{c}\text { STN040 } \\
\text { C1 }\end{array}$ & $\begin{array}{l}294004 \\
832240\end{array}$ & 39 & 0 & 0 & 0 & 0 & stream \\
\hline 138 & 2 & 2 & 52 & YES & 8 & $\begin{array}{c}\text { ECN015 } \\
\text { C1 }\end{array}$ & $\begin{array}{l}300833 \\
835158\end{array}$ & 52 & 0 & 0 & 0 & 0 & stream \\
\hline 139 & 2 & 2 & 38 & $\mathrm{NO}$ & NO DATA & 02315392 & $\begin{array}{c}\text { NO } \\
\text { DATA }\end{array}$ & 38 & 0 & 0 & 0 & 0 & $\begin{array}{c}\text { NO } \\
\text { DATA }\end{array}$ \\
\hline 140 & 3 & 3 & 368 & $\mathrm{NO}$ & NO DATA & 02320500 & $\begin{array}{c}\text { NO } \\
\text { DATA }\end{array}$ & 365 & 0 & 0 & 0 & 3 & $\begin{array}{c}\text { NO } \\
\text { DATA }\end{array}$ \\
\hline 141 & 3 & 2 & 146 & YES & $83(55)$ & $\begin{array}{c}\text { SFR040 } \\
\text { C1 }\end{array}$ & $\begin{array}{l}295451 \\
823448\end{array}$ & 146 & 0 & 0 & 0 & 0 & stream \\
\hline 149 & 1 & 1 & 83 & YES & 83 & $\begin{array}{c}\text { ROR010 } \\
\text { C1 }\end{array}$ & $\begin{array}{l}302544 \\
824105\end{array}$ & 83 & 0 & 0 & 0 & 0 & stream \\
\hline & & & & & Bas & $\sin 5$ & & & & & & & \\
\hline 1 & 4 & 3 & 131 & YES & 29 & 19020002 & $\begin{array}{l}303428 \\
813632\end{array}$ & 131 & 0 & 0 & 0 & 0 & stream \\
\hline 2 & 3 & 3 & 220 & YES & 156 & 19010001 & $\begin{array}{l}304416 \\
814114\end{array}$ & 220 & 0 & 0 & 0 & 0 & stream \\
\hline 51 & 2 & 2 & 95 & YES & 71 & 19010006 & $\begin{array}{l}303115 \\
821348\end{array}$ & 24 & 0 & 71 & 0 & 0 & lake \\
\hline 52 & 3 & 1 & 40 & YES & 12 (14) (14) & NRI & $\begin{array}{l}303453 \\
814109\end{array}$ & 26 & 0 & 0 & 0 & 0 & stream \\
\hline 90 & 1 & 1 & 153 & YES & 153 & 19020005 & $\begin{array}{l}303648 \\
812800\end{array}$ & 0 & 0 & 0 & 153 & 0 & estuary \\
\hline 122 & 1 & 1 & 152 & YES & 152 & 19020013 & $\begin{array}{l}303300 \\
812830\end{array}$ & 152 & 0 & 0 & 0 & & stream \\
\hline & & & & & Bas & $\sin 6$ & & & & & & & \\
\hline 3 & 2 & 2 & 140 & YES & 125 & 20030373 & $\begin{array}{l}292240 \\
813742\end{array}$ & 140 & 0 & 0 & 0 & 0 & stream \\
\hline 4 & 1 & 1 & 34 & YES & 34 & 20030411 & $\begin{array}{l}292332 \\
812620\end{array}$ & 0 & 0 & 34 & 0 & 0 & lake \\
\hline
\end{tabular}


Table 3. Number of stations sampled at each SWAMP site, total number of samples collected at each site by water type, and primary site information

\begin{tabular}{|c|c|c|c|c|c|c|c|c|c|c|c|c|c|}
\hline \multirow{2}{*}{$\begin{array}{c}\text { Site } \\
\text { No. } \\
\text { (see } \\
\text { fig. 1) }\end{array}$} & \multicolumn{2}{|c|}{$\begin{array}{l}\text { Total number of } \\
\text { stations by }\end{array}$} & \multirow{2}{*}{$\begin{array}{c}\text { Total } \\
\text { number } \\
\text { of } \\
\text { samples }\end{array}$} & \multirow{2}{*}{$\begin{array}{l}\text { Primary } \\
\text { stations }\end{array}$} & \multirow{2}{*}{$\begin{array}{c}\text { Total } \\
\text { number of } \\
\text { samples at } \\
\text { primary } \\
\text { station }\end{array}$} & \multirow{2}{*}{$\begin{array}{c}\text { Primary } \\
\text { station } \\
\text { ID } \\
\text { No. }\end{array}$} & \multirow{2}{*}{$\begin{array}{c}\text { Primary } \\
\text { station } \\
\text { Lat/ } \\
\text { Long }\end{array}$} & \multicolumn{5}{|c|}{$\begin{array}{c}\text { Total number of samples } \\
\text { by water type }\end{array}$} & \multirow{2}{*}{$\begin{array}{c}\text { Primary } \\
\text { station } \\
\text { water } \\
\text { type }\end{array}$} \\
\hline & Station ID & Lat/Long & & & & & & Stream & Canal & Lake & $\begin{array}{l}\text { Estu- } \\
\text { ary }\end{array}$ & Spring & \\
\hline \multirow[t]{2}{*}{5} & 4 & 3 & 49 & YES & 29 & 02240800 & 294115 & 40 & 0 & 9 & 0 & 0 & stream \\
\hline & & & & & & & 821224 & & & & & & \\
\hline \multirow[t]{2}{*}{6} & 3 & 3 & 72 & YES & 12 & $1264 \mathrm{~A} 1$ & 293800 & 72 & 0 & 0 & 0 & 0 & stream \\
\hline & & & & & & & 821930 & & & & & & \\
\hline \multirow[t]{2}{*}{7} & 2 & 2 & 103 & YES & 41 & 27010460 & 285721 & 0 & 0 & 0 & 103 & 0 & estuary \\
\hline & & & & & & & 805253 & & & & & & \\
\hline \multirow[t]{2}{*}{8} & 3 & 3 & 78 & YES & 56 & 27010024 & 292030 & 1 & 0 & 0 & 77 & 0 & estuary \\
\hline & & & & & & & 810512 & & & & & & \\
\hline \multirow[t]{2}{*}{9} & 3 & 2 & 130 & YES & $94(35)$ & $\mathrm{CCO} 3$ & 280407 & 1 & 0 & 0 & 129 & 0 & estuary \\
\hline & & & & & & & 803721 & & & & & & \\
\hline \multirow[t]{2}{*}{50} & 4 & 3 & 49 & YES & 29 & 02240800 & 294115 & 40 & 0 & 9 & 0 & 0 & stream \\
\hline & & & & & & & 821224 & & & & & & \\
\hline \multirow[t]{2}{*}{53} & 4 & 4 & 234 & YES & 215 & 20010002 & 291005 & 234 & 0 & 0 & 0 & 0 & stream \\
\hline & & & & & & & 813125 & & & & & & \\
\hline \multirow[t]{2}{*}{54} & 2 & 2 & 65 & YES & 60 & OLK & 292749 & 0 & 0 & 65 & 0 & 0 & lake \\
\hline & & & & & & & 821038 & & & & & & \\
\hline \multirow[t]{2}{*}{55} & 3 & 3 & 50 & YES & 26 & 20030400 & 294734 & 0 & 0 & 50 & 0 & 0 & lake \\
\hline & & & & & & & 815050 & & & & & & \\
\hline \multirow[t]{2}{*}{56} & 6 & 5 & 115 & YES & 26 & 27010579 & 291301 & 115 & 0 & 0 & 0 & 0 & stream \\
\hline & & & & & & & 810632 & & & & & & \\
\hline \multirow[t]{2}{*}{57} & 1 & 1 & 28 & YES & 28 & 27010875 & 284112 & 0 & 0 & 0 & 28 & 0 & estuary \\
\hline & & & & & & & 804847 & & & & & & \\
\hline 58 & 2 & 2 & 188 & YES & 187 & C25S50 & 272818 & 188 & 0 & 0 & 0 & 0 & stream \\
\hline & & & & & & & 802012 & & & & & & \\
\hline 89 & 3 & 3 & 177 & YES & 97 & 02238000 & 285214 & 177 & 0 & 0 & 0 & 0 & stream \\
\hline & & & & & & & 814702 & & & & & & \\
\hline 91 & 3 & 3 & 84 & YES & 7 & 20010455 & 285230 & 84 & 0 & 0 & 0 & 0 & stream \\
\hline & & & & & & & 812922 & & & & & & \\
\hline 92 & 1 & 1 & 9 & YES & 9 & 20020404 & 293109 & 9 & 0 & 0 & 0 & 0 & stream \\
\hline & & & & & & & 815648 & & & & & & \\
\hline 93 & 1 & 1 & 30 & YES & 30 & 20030412 & 295751 & 0 & 0 & 30 & 0 & 0 & lake \\
\hline & & & & & & & 815957 & & & & & & \\
\hline 94 & 3 & 3 & 197 & YES & 156 & 27010037 & 291242 & 0 & 0 & 0 & 197 & 0 & estuary \\
\hline & & & & & & & 810042 & & & & & & \\
\hline 95 & 3 & 2 & 59 & YES & 31 & 27010511 & 280752 & 28 & 0 & 0 & 31 & 0 & estuary \\
\hline & & & & & & & 803701 & & & & & & \\
\hline 121 & 5 & 4 & 482 & NO & NO DATA & $\begin{array}{c}\text { NO } \\
\text { DATA }\end{array}$ & $\begin{array}{c}\text { NO } \\
\text { DATA }\end{array}$ & 252 & 230 & 0 & 0 & 0 & $\begin{array}{c}\text { NO } \\
\text { DATA }\end{array}$ \\
\hline 123 & $\begin{array}{l}5(\text { part1 }) \& \\
2(\text { part2) }\end{array}$ & $5 \& 2$ & 150 & NO & NO DATA & $\begin{array}{c}\text { NO } \\
\text { DATA }\end{array}$ & $\begin{array}{c}\text { NO } \\
\text { DATA }\end{array}$ & $\begin{array}{c}75 \\
(\text { part1) }\end{array}$ & 0 & 75 & 0 & 0 & $\begin{array}{c}\text { NO } \\
\text { DATA }\end{array}$ \\
\hline 124 & 5 & 5 & 329 & YES & 195 & 20020012 & 292222 & 329 & 0 & 0 & 0 & 0 & stream \\
\hline & & & & & & & 815406 & & & & & & \\
\hline 125 & 1 & 1 & 98 & YES & 98 & 20030083 & 301623 & 98 & 0 & 0 & 0 & 0 & stream \\
\hline & & & & & & & 814400 & & & & & & \\
\hline
\end{tabular}


Table 3. Number of stations sampled at each SWAMP site, total number of samples collected at each site by water type, and primary site information

\begin{tabular}{|c|c|c|c|c|c|c|c|c|c|c|c|c|c|}
\hline \multirow{2}{*}{$\begin{array}{c}\text { Site } \\
\text { No. } \\
\text { (see } \\
\text { fig. 1) }\end{array}$} & \multicolumn{2}{|c|}{$\begin{array}{l}\text { Total number of } \\
\text { stations by }\end{array}$} & \multirow{2}{*}{$\begin{array}{c}\text { Total } \\
\text { number } \\
\text { of } \\
\text { samples }\end{array}$} & \multirow{2}{*}{$\begin{array}{l}\text { Primary } \\
\text { stations }\end{array}$} & \multirow{2}{*}{$\begin{array}{c}\text { Total } \\
\text { number of } \\
\text { samples at } \\
\text { primary } \\
\text { station }\end{array}$} & \multirow{2}{*}{$\begin{array}{c}\text { Primary } \\
\text { station } \\
\text { ID } \\
\text { No. }\end{array}$} & \multirow{2}{*}{$\begin{array}{c}\text { Primary } \\
\text { station } \\
\text { Lat/ } \\
\text { Long }\end{array}$} & \multicolumn{5}{|c|}{$\begin{array}{c}\text { Total number of samples } \\
\text { by water type }\end{array}$} & \multirow{2}{*}{$\begin{array}{c}\text { Primary } \\
\text { station } \\
\text { water } \\
\text { type }\end{array}$} \\
\hline & Station ID & Lat/Long & & & & & & Stream & Canal & Lake & $\begin{array}{l}\text { Estu- } \\
\text { ary }\end{array}$ & Spring & \\
\hline \multirow[t]{2}{*}{126} & \multirow[t]{2}{*}{2} & \multirow[t]{2}{*}{2} & \multirow[t]{2}{*}{101} & \multirow[t]{2}{*}{ YES } & \multirow[t]{2}{*}{59} & \multirow[t]{2}{*}{ TOL } & 300359 & \multirow[t]{2}{*}{59} & \multirow[t]{2}{*}{0} & \multirow[t]{2}{*}{0} & \multirow[t]{2}{*}{42} & \multirow[t]{2}{*}{0} & stream \\
\hline & & & & & & & 812212 & & & & & & \\
\hline 127 & 2 & 2 & 73 & YES & 72 & 27010480 & 275510 & 1 & 0 & 0 & 72 & 0 & estuary \\
\hline & & & & & & & 803054 & & & & & & \\
\hline 143 & 1 & 1 & 23 & YES & 23 & 20010521 & 282732 & 23 & 0 & 0 & 0 & 0 & stream \\
\hline & & & & & & & 805648 & & & & & & \\
\hline & & & & & Bas & $\sin 7$ & & & & & & & \\
\hline 24 & 2 & 2 & 24 & YES & 12 & 24020057 & 275323 & 24 & 0 & 0 & 0 & 0 & stream \\
\hline & & & & & & & 815825 & & & & & & \\
\hline 25 & 6 & 6 & 127 & YES & 121 & 25030408 & 270600 & 0 & 0 & 0 & 121 & 0 & estuary \\
\hline & & & & & & & 821959 & & & & & & \\
\hline 26 & NO DATA & & & & & & & & & & & & \\
\hline 28 & 1 & 1 & 83 & YES & 83 & 25010012 & 265356 & 0 & 0 & 0 & 83 & 0 & estuary \\
\hline & & & & & & & 820717 & & & & & & \\
\hline 29 & 4 & 4 & 217 & YES & 213 & 25020001 & 265642 & 1 & 0 & 0 & 216 & 0 & estuary \\
\hline & & & & & & & 820326 & & & & & & \\
\hline 32 & 1 & 1 & 164 & YES & 164 & 25020120 & 265831 & 164 & 0 & 0 & 0 & 0 & stream \\
\hline & & & & & & & 815316 & & & & & & \\
\hline 33 & 2 & 2 & 133 & YES & 61 & BR-3 & 272445 & 61 & 0 & 72 & 0 & 0 & stream \\
\hline & & & & & & & 822721 & & & & & & \\
\hline 34 & 3 & 3 & 189 & YES & 178 & 24010013 & 273940 & 189 & 0 & 0 & 0 & 0 & stream \\
\hline & & & & & & & 821755 & & & & & & \\
\hline 35 & 4 & 4 & 550 & YES & 8 & 24030013 & 281108 & 550 & 0 & 0 & 0 & 0 & stream \\
\hline & & & & & & & 821104 & & & & & & \\
\hline 36 & 2 & 2 & 247 & YES & 241 & 24010022 & 275005 & 247 & 0 & 0 & 0 & 0 & stream \\
\hline & & & & & & & 822050 & & & & & & \\
\hline 38 & 3 & 3 & 253 & NO & NO DATA & $\begin{array}{l}\text { NO } \\
\text { DATA }\end{array}$ & $\begin{array}{c}\text { NO } \\
\text { DATA }\end{array}$ & 253 & 0 & 0 & 0 & 0 & $\begin{array}{l}\text { NO } \\
\text { DATA }\end{array}$ \\
\hline 65 & 5 & 5 & 77 & YES & 27 & 25020459 & 271809 & 44 & 0 & 0 & 33 & 0 & stream \\
\hline & & & & & & & 815048 & & & & & & \\
\hline 66 & 4 & 3 & 176 & YES & 17 & FLO0018 & 271725 & 176 & 0 & 0 & 0 & 0 & stream \\
\hline & & & & & & & 821445 & & & & & & \\
\hline 67 & 1 & 1 & 6 & YES & 6 & FLO0099 & 270659 & 6 & 0 & 0 & 0 & 0 & stream \\
\hline & & & & & & & 822524 & & & & & & \\
\hline 68 & 1 & 1 & 12 & YES & 12 & FLO0017 & 273242 & 12 & 0 & 0 & 0 & 0 & stream \\
\hline & & & & & & & 822332 & & & & & & \\
\hline 69 & 3 & 3 & 189 & YES & 3 & 24010018 & 273945 & 189 & 0 & 0 & 0 & 0 & stream \\
\hline & & & & & & & 821804 & & & & & & \\
\hline 70 & 3 & 2 & 238 & YES & 11 & 24020059 & 274748 & 234 & 0 & 0 & 0 & 4 & stream \\
\hline & & & & & & & 820703 & & & & & & \\
\hline 71 & 1 & 1 & 82 & YES & 82 & 24030007 & 275943 & 0 & 0 & 0 & 82 & 0 & estuary \\
\hline & & & & & & & 822756 & & & & & & \\
\hline
\end{tabular}


Table 3. Number of stations sampled at each SWAMP site, total number of samples collected at each site by water type, and primary site information

\begin{tabular}{|c|c|c|c|c|c|c|c|c|c|c|c|c|c|}
\hline \multirow{2}{*}{$\begin{array}{c}\text { Site } \\
\text { No. } \\
\text { (see } \\
\text { fig. 1) }\end{array}$} & \multicolumn{2}{|c|}{$\begin{array}{l}\text { Total number of } \\
\text { stations by }\end{array}$} & \multirow{2}{*}{$\begin{array}{c}\text { Total } \\
\text { number } \\
\text { of } \\
\text { samples }\end{array}$} & \multirow{2}{*}{$\begin{array}{l}\text { Primary } \\
\text { stations }\end{array}$} & \multirow{2}{*}{$\begin{array}{c}\text { Total } \\
\text { number of } \\
\text { samples at } \\
\text { primary } \\
\text { station }\end{array}$} & \multirow{2}{*}{$\begin{array}{c}\text { Primary } \\
\text { station } \\
\text { ID } \\
\text { No. }\end{array}$} & \multirow{2}{*}{$\begin{array}{c}\text { Primary } \\
\text { station } \\
\text { Lat/ } \\
\text { Long }\end{array}$} & \multicolumn{5}{|c|}{$\begin{array}{c}\text { Total number of samples } \\
\text { by water type }\end{array}$} & \multirow{2}{*}{$\begin{array}{c}\text { Primary } \\
\text { station } \\
\text { water } \\
\text { type }\end{array}$} \\
\hline & Station ID & Lat/Long & & & & & & Stream & Canal & Lake & $\begin{array}{l}\text { Estu- } \\
\text { ary }\end{array}$ & Spring & \\
\hline \multirow[t]{2}{*}{72} & 1 & 1 & 102 & YES & 102 & 24040152 & 280130 & 102 & 0 & 0 & 0 & 0 & stream \\
\hline & & & & & & & 823452 & & & & & & \\
\hline 73 & 3 & 3 & 270 & NO & NO DATA & $\begin{array}{c}\text { NO } \\
\text { DATA }\end{array}$ & $\begin{array}{c}\text { NO } \\
\text { DATA }\end{array}$ & 270 & 0 & 0 & 0 & 0 & $\begin{array}{c}\text { NO } \\
\text { DATA }\end{array}$ \\
\hline 74 & 1 & 1 & 7 & NO & NO DATA & $\begin{array}{c}\text { NO } \\
\text { DATA }\end{array}$ & $\begin{array}{c}\text { NO } \\
\text { DATA }\end{array}$ & 7 & 0 & 0 & 0 & 0 & $\begin{array}{c}\text { NO } \\
\text { DATA }\end{array}$ \\
\hline 101 & 1 & 1 & 11 & YES & 11 & 25020014 & $\begin{array}{l}272441 \\
814136\end{array}$ & 11 & 0 & 0 & 0 & 0 & stream \\
\hline 102 & 1 & 1 & 11 & YES & 11 & FLO0021 & $\begin{array}{l}272537 \\
820818\end{array}$ & 11 & 0 & 0 & 0 & 0 & stream \\
\hline 103 & 1 & 1 & 4 & YES & 4 & FLO0100 & $\begin{array}{l}271855 \\
822811\end{array}$ & 4 & 0 & 0 & 0 & 0 & stream \\
\hline 104 & 2 & 2 & 249 & YES & 59 & UM-1 & $\begin{array}{l}273051 \\
822201\end{array}$ & 249 & 0 & 0 & 0 & 0 & stream \\
\hline 105 & 3 & 3 & 24 & YES & 7 & 24010017 & $\begin{array}{l}273858 \\
821740\end{array}$ & 24 & 0 & 0 & 0 & 0 & stream \\
\hline 106 & 2 & 2 & 553 & YES & 279 & 24020019 & $\begin{array}{l}275140 \\
820806\end{array}$ & 553 & 0 & 0 & 0 & 0 & stream \\
\hline 107 & 1 & 1 & 19 & YES & 19 & FLO0014 & $\begin{array}{l}281136 \\
820923\end{array}$ & 19 & 0 & 0 & 0 & 0 & stream \\
\hline 108 & 5 & 4 & 126 & YES & 9 & STA0053 & $\begin{array}{l}282613 \\
823723\end{array}$ & 0 & 0 & 126 & 0 & 0 & lake \\
\hline 109 & 1 & 1 & 6 & YES & 6 & FLO0090 & $\begin{array}{l}285930 \\
822117\end{array}$ & 6 & 0 & 0 & 0 & 0 & stream \\
\hline 132 & 5 & 5 & 97 & NO & NO DATA & $\begin{array}{c}\text { NO } \\
\text { DATA }\end{array}$ & $\begin{array}{c}\text { NO } \\
\text { DATA }\end{array}$ & 15 & & & & & \\
\hline 134 & 2 & 2 & 553 & YES & 274 & 24020008 & $\begin{array}{l}275153 \\
820808\end{array}$ & 553 & 0 & 0 & 0 & 0 & stream \\
\hline 135 & 4 & 3 & 55 & YES & $6(29)$ & FLO0098 & $\begin{array}{l}283208 \\
823749\end{array}$ & 26 & 0 & 0 & 29 & 0 & stream \\
\hline 136 & 5 & 5 & 86 & YES & 7 & FLO0091 & $\begin{array}{l}290259 \\
822654\end{array}$ & 86 & 0 & 0 & 0 & 0 & stream \\
\hline \multicolumn{14}{|c|}{ Basin 8} \\
\hline 23 & 1 & 1 & 354 & YES & 354 & L004 & $\begin{array}{l}265905 \\
804233\end{array}$ & 0 & 0 & 354 & 0 & 0 & lake \\
\hline 27 & 3 & 2 & 1358 & YES & 1309 & S65D & $\begin{array}{l}271845 \\
810120\end{array}$ & 49 & 1309 & 0 & 0 & 0 & canal \\
\hline 30 & 2 & 2 & 83 & YES & 78 & 28020185 & $\begin{array}{l}263203 \\
815643\end{array}$ & 5 & 0 & 0 & 78 & 0 & estuary \\
\hline 31 & 4 & 3 & 273 & YES & 80 & 26010238 & $\begin{array}{l}280900 \\
812628\end{array}$ & 273 & 0 & 0 & 0 & 0 & stream \\
\hline 39 & 4 & 3 & 11 & YES & 2 & 28020188 & $\begin{array}{l}262957 \\
815116\end{array}$ & 9 & 2 & 0 & 0 & 0 & canal \\
\hline
\end{tabular}


Table 3. Number of stations sampled at each SWAMP site, total number of samples collected at each site by water type, and primary site information

\begin{tabular}{|c|c|c|c|c|c|c|c|c|c|c|c|c|c|}
\hline \multirow{2}{*}{$\begin{array}{l}\text { Site } \\
\text { No. } \\
\text { (see } \\
\text { fig. 1) }\end{array}$} & \multicolumn{2}{|c|}{$\begin{array}{l}\text { Total number of } \\
\text { stations by }\end{array}$} & \multirow{2}{*}{$\begin{array}{c}\text { Total } \\
\text { number } \\
\text { of } \\
\text { samples }\end{array}$} & \multirow{2}{*}{$\begin{array}{l}\text { Primary } \\
\text { stations }\end{array}$} & \multirow{2}{*}{$\begin{array}{c}\text { Total } \\
\text { number of } \\
\text { samples at } \\
\text { primary } \\
\text { station }\end{array}$} & \multirow{2}{*}{$\begin{array}{c}\text { Primary } \\
\text { station } \\
\text { ID } \\
\text { No. }\end{array}$} & \multirow{2}{*}{$\begin{array}{c}\text { Primary } \\
\text { station } \\
\text { Lat/ } \\
\text { Long }\end{array}$} & \multicolumn{5}{|c|}{$\begin{array}{c}\text { Total number of samples } \\
\text { by water type }\end{array}$} & \multirow{2}{*}{$\begin{array}{c}\text { Primary } \\
\text { station } \\
\text { water } \\
\text { type }\end{array}$} \\
\hline & Station ID & Lat/Long & & & & & & Stream & Canal & Lake & $\begin{array}{l}\text { Estu- } \\
\text { ary }\end{array}$ & Spring & \\
\hline \multirow[t]{2}{*}{40} & \multirow[t]{2}{*}{5} & \multirow[t]{2}{*}{4} & \multirow[t]{2}{*}{420} & \multirow[t]{2}{*}{ YES } & \multirow[t]{2}{*}{$156(237)$} & \multirow[t]{2}{*}{26010592} & 265556 & 406 & 14 & \multirow[t]{2}{*}{0} & & & \multirow[t]{2}{*}{ stream } \\
\hline & & & & & & & 811854 & & & & & & \\
\hline \multirow[t]{2}{*}{41} & 2 & 2 & 73 & YES & 8 & 28040387 & 255111 & 8 & 65 & 0 & 0 & 0 & stream \\
\hline & & & & & & & 801134 & & & & & & \\
\hline 59 & 3 & 2 & 1,383 & YES & 1335 & $\mathrm{~S} 65 \mathrm{C}$ & 272401 & 48 & 1335 & 0 & 0 & 0 & canal \\
\hline & & & & & & & 810657 & & & & & & \\
\hline 60 & 4 & 3 & 606 & YES & 584 & L002 & 270506 & 4 & 0 & 602 & 0 & 0 & lake \\
\hline & & & & & & & 804717 & & & & & & \\
\hline 61 & 4 & 3 & 525 & YES & 11 & 26010582 & 265740 & 525 & 0 & 0 & 0 & 0 & stream \\
\hline & & & & & & & 810722 & & & & & & \\
\hline 62 & 1 & 1 & 323 & YES & 323 & L007 & 264635 & 0 & 0 & 0 & 323 & 0 & estuary \\
\hline & & & & & & & 804719 & & & & & & \\
\hline 63 & 2 & 2 & 19 & NO & NO DATA & $\begin{array}{c}\text { NO } \\
\text { DATA }\end{array}$ & $\begin{array}{c}\text { NO } \\
\text { DATA }\end{array}$ & 0 & 0 & 0 & 19 & 0 & $\begin{array}{c}\text { NO } \\
\text { DATA }\end{array}$ \\
\hline 64 & 7 & 6 & 744 & YES & $153(468)$ & 28020022 & 265023 & 657 & 87 & 0 & 0 & 0 & stream \\
\hline & & & & & & & 810518 & & & & & & \\
\hline 96 & 5 & 5 & 277 & YES & 67 & S68 & 271951 & 240 & 0 & 37 & 0 & 0 & stream \\
\hline & & & & & & & 811510 & & & & & & \\
\hline 97 & 2 & 2 & 11 & YES & 8 & 26010583 & 270358 & 11 & 0 & 0 & 0 & 0 & stream \\
\hline & & & & & & & 805843 & & & & & & \\
\hline 98 & 1 & 1 & 671 & YES & 671 & L006 & 294922 & 0 & 0 & 671 & 0 & 0 & lake \\
\hline & & & & & & & 804719 & & & & & & \\
\hline 99 & 3 & 3 & 174 & YES & 7 & 28030047 & 261024 & 86 & 88 & 0 & 0 & 0 & stream \\
\hline & & & & & & & 814705 & & & & & & \\
\hline 100 & 3 & 3 & 22 & YES & 12 & 28020041 & 264349 & 22 & 0 & 0 & 0 & 0 & stream \\
\hline & & & & & & & 814208 & & & & & & \\
\hline 128 & 1 & 1 & 31 & NO & NO DATA & NO & NO & 0 & 0 & 31 & 0 & 0 & NO \\
\hline & & & & & & & & & & & & & DAIA \\
\hline 129 & 1 & 1 & 507 & YES & 507 & L005 & 265730 & 0 & 0 & 507 & 0 & 0 & lake \\
\hline & & & & & & & 805840 & & & & & & \\
\hline 130 & 4 & 3 & 204 & YES & $2(93)$ & 28030038 & 261003 & 111 & 93 & 0 & 0 & 0 & stream \\
\hline & & & & & & & 814603 & & & & & & \\
\hline 131 & 4 & 3 & 341 & YES & $215(9)$ & 28020006 & 264248 & 231 & 110 & 0 & 0 & 0 & stream \\
\hline & & & & & & & 813638 & & & & & & \\
\hline 133 & 1 & 1 & 79 & YES & 79 & L4 & 252815 & 79 & 0 & 0 & 0 & 0 & stream \\
\hline & & & & & & & 802246 & & & & & & \\
\hline 145 & 2 & 2 & 192 & YES & 187 & C15S40 & 262527 & 192 & 0 & 0 & 0 & 0 & stream \\
\hline & & & & & & & 800428 & & & & & & \\
\hline 146 & 5 & 4 & 510 & YES & 398 & S65A & 273944 & & 0 & 0 & 0 & 0 & stream \\
\hline & & & & & & & 810803 & & & & & & \\
\hline 147 & 4 & 4 & 143 & YES & 32 & SCC & 282437 & 143 & 0 & 0 & 0 & 0 & stream \\
\hline & & & & & & & 812603 & & & & & & \\
\hline 148 & NO DATA & & & & & & & & & & & & \\
\hline 150 & 26 & 22 & 799 & YES & 105 & SE 10 & 270646 & 666 & 28 & 0 & 105 & 0 & estuary \\
\hline & & & & & & & 801704 & & & & & & \\
\hline
\end{tabular}


Table 4. Number of surface-water-quality samples collected at each site in the St. Marks River Basin

\begin{tabular}{|c|c|c|c|c|c|}
\hline Site name & Station ID number & $\begin{array}{l}\text { No. of } \\
\text { samples }\end{array}$ & Latitude & Longitude & Water body type \\
\hline 11B HORN SPRING NR WOODVILLE & 301909084074400 & 1 & 301909 & 840744 & SPRING \\
\hline 11B KINI SPRING NR WOODVILLE & 301643084203400 & 1 & 301643 & 842034 & SPRING \\
\hline AENON CHURCH ROAD & 302520084223901 & 4 & 302520 & 842239 & CANAL \\
\hline AIRPORT DRIVE AT EPPES DRIVE & 302559084181800 & 5 & 302559 & 841818 & CANAL \\
\hline APAKIN NENE AT EAST INDIAN HEAD DRIVE & 302549084152900 & 6 & 302549 & 841529 & STREAM \\
\hline APALACHEE BAY NEAR SHELL PT & 22030060 & 5 & 300319 & 841735 & ESTUARY \\
\hline AREA SWIMMING BEACH & 50620 & 121 & 302418 & 842430 & LAKE \\
\hline AREA SWIMMING BEACH & 50621 & 115 & 302418 & 842430 & LAKE \\
\hline BIG BOGGY BRANCH & 301001084131901 & 8 & 301001 & 841319 & STREAM \\
\hline BLACK CR. C1541 BAUM RD EC0REG.65H & 22030066 & 3 & 303003 & 840449 & STREAM \\
\hline BOGGY CR AT MAGAZINE RD & 22030059 & 3 & 301016 & 841315 & STREAM \\
\hline BOONE BOULEVARD AT MONTICELLO DRIVE & 302801084172200 & 2 & 302801 & 841722 & CANAL \\
\hline BORROW PIT 348 & 50656 & 8 & 301409 & 843210 & LAKE \\
\hline BORROW PIT 360 & 50655 & 8 & 302127 & 843154 & LAKE \\
\hline BORROW PIT 383 & 50664 & 2 & 301948 & 842819 & LAKE \\
\hline BRADFORD BROOK & $1247 \mathrm{~A} 1$ & 12 & 302130 & 841800 & STREAM \\
\hline BRIARWOOD WEST TRAILER PARK INFL & 22021001 & 8 & 302422 & 841940 & LAKE \\
\hline BUCK LAKE ROAD & 302747084101501 & 5 & 302747 & 841015 & CANAL \\
\hline CANAL STREET AT RAILROAD AVE. & 302555084172400 & 4 & 302555 & 841724 & CANAL \\
\hline CANEY CREEK NR MONTICELLO & 2326598 & 4 & 303052 & 835624 & STREAM \\
\hline CARRINGTON CT. IN HUNTINGDON ESTATES & 303007084203601 & 4 & 303007 & 842036 & CANAL \\
\hline CENTERVILLE ROAD AT CAPITAL CIRCLE & 302842084141200 & 7 & 302842 & 841412 & CANAL \\
\hline CENTERVILLE ROAD AT TARPON DRIVE & 302808084150000 & 9 & 302808 & 841500 & CANAL \\
\hline $\begin{array}{l}\text { CENTRAL DD AT ORANGE AVE AT } \\
\text { TALLAHASSEE }\end{array}$ & 2327015 & 2 & 302210 & 841820 & LAKE \\
\hline $\begin{array}{l}\text { CITY OF TALLAHASSEE AIRPORT WELL NR } \\
\text { TALLAHASSEE }\end{array}$ & 302424084311301 & 3 & 302424 & 842113 & STREAM \\
\hline CLEAR LAKE & 50617 & 6 & 302056 & 842446 & LAKE \\
\hline CLEVE JONES WELL NR TALLAHASSEE & 302409084183801 & 2 & 302409 & 841838 & STREAM \\
\hline COPELAND SINK DRAIN AT LLOYD & 2326800 & 2 & 302840 & 840051 & STREAM \\
\hline DALE MABRY PLANT) & $1247 \mathrm{BB}$ & 12 & 302530 & 841800 & STREAM \\
\hline DEER HILLS TRAILER PK STP INFL & 22031013 & 9 & 302615 & 842158 & LAKE \\
\hline EIGHTMILE POND/AMES SINK-OAKRIDE RD & 301926084182001 & 9 & 301926 & 841820 & STREAM \\
\hline EIGHTMILE POND NR WOODVILLE & 301926084180700 & 1 & 301926 & 841807 & LAKE \\
\hline F LOST LAKE REC AREA & 50630 & 103 & 302142 & 842307 & LAKE \\
\hline F LOST LAKE REC AREA & 50631 & 14 & 302142 & 842307 & LAKE \\
\hline FANLEW & 301624084032401 & 1 & 301624 & 840324 & STREAM \\
\hline GLEN MILLER WELL AT HILLIARDVILLE & 301707084234301 & 2 & 301707 & 842343 & STREAM \\
\hline $\begin{array}{l}\text { GOVERNORS SQ MALL DD AT PARK AV AT } \\
\text { TALLAHASSEE }\end{array}$ & 2326842 & 1 & 302629 & 841441 & STREAM \\
\hline GULF COAST NO 1 & 300618084193801 & 1 & 300618 & 841938 & STREAM \\
\hline HADLEY ROAD NEAR RAYMOND DIEHL RD & 303012084141700 & 5 & 303012 & 841417 & CANAL \\
\hline HORN SPRING & 301909084074401 & 2 & 301909 & 840744 & SPRING \\
\hline HUDSON WELL AT HILLIARDVILLE & 301741084240301 & 2 & 301741 & 842403 & STREAM \\
\hline HWY 27 AT RAYMOND TUCKER ROAD & 302516084095601 & 4 & 302516 & 840956 & CANAL \\
\hline INDIAN SPRINGS & 301502084194201 & 2 & 301502 & 841942 & SPRING \\
\hline INDIAN SPRINGS NR WOODVILLE & 301502084194200 & 1 & 301502 & 841942 & SPRING \\
\hline
\end{tabular}


Table 4. Number of surface-water-quality samples collected at each site in the St. Marks River Basin (Continued)

\begin{tabular}{|c|c|c|c|c|c|}
\hline Site name & Station ID number & $\begin{array}{c}\text { No. of } \\
\text { samples }\end{array}$ & Latitude & Longitude & Water body type \\
\hline INF SOUTHERN BELLE MHP STP & 22031051 & 8 & 302727 & 842230 & LAKE \\
\hline JOSEPH BELLAMY WELL NR MONTICELLO & 303001083553401 & 3 & 303001 & 835534 & STREAM \\
\hline KINI SPRING NR WOODVILLE & 301643084203401 & 9 & 301643 & 842034 & SPRING \\
\hline L MUNSON \#2 DITCH DOWN DOT PLT E & 22030034 & 4 & 302425 & 841833 & STREAM \\
\hline L MUNSON \#3 DITCH SPRINGHILL RD & 22030035 & 2 & 302409 & 841835 & STREAM \\
\hline L MUNSON \#4 60 YDS FR NW CORNER & 22030036 & 1 & 302220 & 841843 & LAKE \\
\hline L MUNSON \#6 MID ARM NW NE CNR L & 22030038 & 4 & 302215 & 841835 & LAKE \\
\hline LAKE ARROWHEAD1 IN LEON CO. & ARROWHEAD1 & 41 & 303400 & 841303 & LAKE \\
\hline LAKE ARROWHEAD2 IN LEON CO. & ARROWHEAD2 & 1 & 303400 & 841303 & LAKE \\
\hline LAKE ARROWHEAD3 IN LEON CO. & ARROWHEAD3 & & 303400 & 841303 & LAKE \\
\hline LAKE BELMONT1 IN LEON CO. & BELMONT1 & 22 & 303301 & 841045 & LAKE \\
\hline LAKE BELMONT2 IN LEON CO. & BELMONT2 & 22 & 303301 & 841045 & LAKE \\
\hline LAKE BELMONT3 IN LEON CO. & BELMONT3 & 22 & 303301 & 841045 & LAKE \\
\hline LAKE BLAIRSTONE1 IN LEON CO. & BLAIRSTONE1 & 24 & 302450 & 841525 & LAKE \\
\hline LAKE BLAIRSTONE2 IN LEON CO. & BLAIRSTONE2 & 24 & 302450 & 841525 & LAKE \\
\hline LAKE BLAIRSTONE3 IN LEON CO. & BLAIRSTONE3 & 24 & 302450 & 841525 & LAKE \\
\hline LAKE BLUE HERON1 IN LEON CO. & BLUE HERON1 & 30 & 303602 & 841415 & LAKE \\
\hline LAKE BLUE HERON2 IN LEON CO. & BLUE HERON2 & 30 & 303602 & 841415 & LAKE \\
\hline LAKE BLUE HERON3 IN LEON CO. & BLUE HERON3 & 30 & 303602 & 841415 & LAKE \\
\hline LAKE BOCKUS1 IN LEON CO. & BOCKUS1 & 20 & 303505 & 841309 & LAKE \\
\hline LAKE BOCKUS2 IN LEON CO. & BOCKUS2 & 20 & 303505 & 841309 & LAKE \\
\hline LAKE BOCKUS3 IN LEON CO. & BOCKUS3 & 20 & 303505 & 841309 & LAKE \\
\hline LAKE BRADFORD & 50660 & 2 & 302407 & 842010 & LAKE \\
\hline LAKE BRADFORD & 302420084200601 & 3 & 302420 & 842006 & LAKE \\
\hline LAKE BRADFORD NR TALLAHASSEE & 2327010 & 5 & 302410 & 842005 & LAKE \\
\hline LAKE BRADFORD RD STP INFL & 22031005 & 12 & 302355 & 841935 & LAKE \\
\hline LAKE BRADFORD1 IN LEON CO. & BRADFORD1 & 73 & 302409 & 842029 & LAKE \\
\hline LAKE BRADFORD2 IN LEON CO. & BRADFORD2 & 73 & 302409 & 842029 & LAKE \\
\hline LAKE BRADFORD3 IN LEON CO. & BRADFORD3 & 73 & 302409 & 842029 & LAKE \\
\hline LAKE CAROLYN1 IN LEON CO. & CAROLYN1 & 12 & 303306 & 841225 & LAKE \\
\hline LAKE CAROLYN2 IN LEON CO. & CAROLYN2 & 12 & 303306 & 841225 & LAKE \\
\hline LAKE CAROLYN3 IN LEON CO. & CAROLYN3 & 12 & 303306 & 841225 & LAKE \\
\hline LAKE CASCADE1 IN LEON CO. & CASCADE1 & 11 & 302510 & 842138 & LAKE \\
\hline LAKE CASCADE2 IN LEON CO. & CASCADE2 & 11 & 302510 & 842138 & LAKE \\
\hline LAKE CASCADE3 IN LEON CO. & CASCADE3 & 1 & 302510 & 842138 & LAKE \\
\hline LAKE DIANE1 IN LEON CO. & DIANE1 & 33 & 303538 & 841421 & LAKE \\
\hline LAKE DIANE2 IN LEON CO. & DIANE2 & 33 & 303538 & 841421 & LAKE \\
\hline LAKE DIANE3 IN LEON CO. & DIANE3 & 33 & 303538 & 841421 & LAKE \\
\hline LAKE ELIZABETH1 IN LEON CO. & ELIZABETH1 & 7 & 302936 & 841749 & LAKE \\
\hline LAKE ELIZABETH2 IN LEON CO. & ELIZABETH2 & 7 & 302936 & 841749 & LAKE \\
\hline LAKE ELIZABETH3 IN LEON CO. & ELIZABETH3 & 7 & 302936 & 841749 & LAKE \\
\hline LAKE ELLA \#1 SOUTH SHORE & 22030051 & 1 & 302736 & 841648 & LAKE \\
\hline LAKE ELLA \#2 NORTH SHORE & 22030052 & 1 & 302743 & 841647 & LAKE \\
\hline LAKE ELLEN-WAKULLA CO & 119 & 3 & 300240 & 841821 & LAKE \\
\hline LAKE ERIE1 IN LEON CO. & ERIE1 & 52 & 302205 & 840746 & LAKE \\
\hline LAKE ERIE2 IN LEON CO. & ERIE2 & 52 & 302205 & 840746 & LAKE \\
\hline LAKE ERIE3 IN LEON CO. & ERIE3 & 52 & 302205 & 840746 & LAKE \\
\hline
\end{tabular}


Table 4. Number of surface-water-quality samples collected at each site in the St. Marks River Basin (Continued)

\begin{tabular}{|c|c|c|c|c|c|}
\hline Site name & Station ID number & $\begin{array}{c}\text { No. of } \\
\text { samples }\end{array}$ & Latitude & Longitude & Water body type \\
\hline LAKE HALL1 IN LEON CO. & HALL1 & 45 & 303114 & 841452 & LAKE \\
\hline LAKE HALL2 IN LEON CO. & HALL2 & 45 & 303114 & 841452 & LAKE \\
\hline LAKE HALL3 IN LEON CO. & HALL3 & 45 & 303114 & 841452 & LAKE \\
\hline LAKE HIAWATHA & 50661 & 2 & 302457 & 842107 & LAKE \\
\hline LAKE HIAWATHA & 3B3-002 & 1 & 302447 & 842100 & LAKE \\
\hline LAKE HIAWATHA1 IN LEON CO. & HIAWATHA073-1 & 75 & 302436 & 842053 & LAKE \\
\hline LAKE HIAWATHA2 IN LEON CO. & HIAWATHA073-2 & 75 & 302436 & 842053 & LAKE \\
\hline LAKE HIAWATHA3 IN LEON CO. & HIAWATHA073-3 & 1 & 302436 & 842053 & LAKE \\
\hline LAKE HORNE SPRINGS1 IN LEON CO. & HORNE SPRINGS1 & 23 & 301905 & 840753 & LAKE \\
\hline LAKE HORNE SPRINGS2 IN LEON CO. & HORNE SPRINGS2 & 23 & 301905 & 840753 & LAKE \\
\hline LAKE HORNE SPRINGS3 IN LEON CO. & HORNE SPRINGS3 & 23 & 301905 & 840753 & LAKE \\
\hline LAKE IAMONIA1 IN LEON CO. & IAMONIA1 & 3 & 303801 & 841448 & LAKE \\
\hline LAKE IAMONIA2 IN LEON CO. & IAMONIA2 & 3 & 303801 & 841448 & LAKE \\
\hline LAKE IAMONIA3 IN LEON CO. & IAMONIA3 & 3 & 303801 & 841448 & LAKE \\
\hline $\begin{array}{l}\text { LAKE JACKSON AT NWFWMD STORMWATER } \\
\text { RETENTION POND }\end{array}$ & 302900084175700 & 3 & 302900 & 841757 & LAKE \\
\hline LAKE LAFAYATTE \#3 WEST DIKE PINE & 22030047 & 4 & 302636 & 841033 & LAKE \\
\hline LAKE LAFAYATTE \#4 N DIKE ALFORD & 22030048 & 4 & 302716 & 840910 & LAKE \\
\hline LAKE LAFAYETTE \#5 CHAIRES ROAD C & 22030049 & 3 & 302535 & 840705 & LAKE \\
\hline LAKE LAFAYETTE AB PINEY Z LAKE & 302628084113101 & 3 & 302628 & 841131 & LAKE \\
\hline LAKE LAFAYETTE E SIDE SR 261 & 22030045 & 3 & 302715 & 841322 & LAKE \\
\hline LAKE MACLAY1 IN LEON CO. & MACLAY1 & 45 & 303057 & 841447 & LAKE \\
\hline LAKE MACLAY2 IN LEON CO. & MACLAY2 & 45 & 303057 & 841447 & LAKE \\
\hline LAKE MICCOSUKEE & 303144083584101 & 3 & 303144 & 835841 & LAKE \\
\hline LAKE MICCOSUKEE-JEFFERSON CO & 263 & 5 & 303614 & 840015 & LAKE \\
\hline LAKE MICCOSUKEE (0.8 MI N OF CENTER) & 303420083584004 & 1 & 303420 & 835840 & LAKE \\
\hline LAKE MICCOSUKEE (1 MI S OF CENTER) & 303420083584002 & 1 & 303420 & 835840 & LAKE \\
\hline LAKE MICCOSUKEE (1.5 MI S OF CENTER) & 303420083584001 & 1 & 303420 & 835840 & LAKE \\
\hline LAKE MICCOSUKEE (2 MI NW OF CENTER) & 303420083584005 & 1 & 303420 & 835840 & LAKE \\
\hline LAKE MICCOSUKEE (2.5 MI NW OF CENTER) & 303420083584006 & 1 & 303420 & 835840 & LAKE \\
\hline LAKE MICCOSUKEE (3.5 MI NW OF CENTER) & 303420083584007 & 1 & 303420 & 835840 & LAKE \\
\hline LAKE MICCOSUKEE (AT CENTER) & 303420083584003 & 1 & 303420 & 835840 & LAKE \\
\hline LAKE MICCOSUKEE \#1 REEVES LANDIN & 22030053 & 2 & 303623 & 835957 & LAKE \\
\hline LAKE MICCOSUKEE \#2 NE POINT & 22030054 & 2 & 303448 & 835918 & LAKE \\
\hline LAKE MICCOSUKEE \#3 PANTHER CREEK & 22030055 & 1 & 303406 & 835900 & LAKE \\
\hline LAKE MICCOSUKEE \#4 SOUTH WEST PO & 22030056 & 1 & 303342 & 835824 & LAKE \\
\hline LAKE MICCOSUKEE NR MICCOSUKEE & 2326600 & 18 & 303614 & 840015 & LAKE \\
\hline LAKE MINNIEHAHA1 IN LEON CO. & MINNIEHAHA1 & 74 & 302450 & 842101 & LAKE \\
\hline LAKE MINNIEHAHA2 IN LEON CO. & MINNIEHAHA2 & 74 & 302450 & 842101 & LAKE \\
\hline LAKE MINNIEHAHA3 IN LEON CO. & MINNIEHAHA3 & 1 & 302450 & 842101 & LAKE \\
\hline LAKE MONKEY BUSINES1 IN LEON CO. & MONKEY BUSINES1 & 26 & 303621 & 841356 & LAKE \\
\hline LAKE MONKEY BUSINES2 IN LEON CO. & MONKEY BUSINES2 & 26 & 303621 & 841356 & LAKE \\
\hline LAKE MONKEY BUSINES3 IN LEON CO. & MONKEY BUSINES3 & 26 & 303621 & 841356 & LAKE \\
\hline LAKE MOORE1 IN LEON CO. & MOORE1 & 23 & 302331 & 842412 & LAKE \\
\hline LAKE MOORE2 IN LEON CO. & MOORE2 & 23 & 302331 & 842412 & LAKE \\
\hline LAKE MOORE3 IN LEON CO. & MOORE3 & 23 & 302331 & 842412 & LAKE \\
\hline LAKE MUNSON & 124701 & 3 & 302214 & 841847 & LAKE \\
\hline
\end{tabular}


Table 4. Number of surface-water-quality samples collected at each site in the St. Marks River Basin (Continued)

\begin{tabular}{|c|c|c|c|c|c|}
\hline Site name & Station ID number & $\begin{array}{c}\text { No. of } \\
\text { samples }\end{array}$ & Latitude & Longitude & Water body type \\
\hline LAKE MUNSON & 124702 & 3 & 302158 & 841808 & LAKE \\
\hline LAKE MUNSON-LEON CO & 282 & 12 & 302209 & 841830 & LAKE \\
\hline LAKE MUNSON \#1 & 302212084182001 & 26 & 302212 & 841820 & LAKE \\
\hline LAKE MUNSON \#10 CENTER OF LAKE & 22030042 & 4 & 302206 & 841826 & LAKE \\
\hline LAKE MUNSON \#11 SW CORNER OF LAKE & 22030043 & 1 & 302150 & 841859 & LAKE \\
\hline LAKE MUNSON \#2 & 302214084183301 & 27 & 302214 & 841833 & LAKE \\
\hline LAKE MUNSON \#3 & 302220084185001 & 27 & 302220 & 841850 & LAKE \\
\hline LAKE MUNSON \#4 & 302205084185301 & 26 & 302205 & 841853 & LAKE \\
\hline LAKE MUNSON \#5 & 302158084184001 & 26 & 302158 & 841840 & LAKE \\
\hline LAKE MUNSON \#6 & 302202084182401 & 26 & 302202 & 841824 & LAKE \\
\hline LAKE MUNSON \#7 & 302225084182601 & 26 & 302225 & 841826 & LAKE \\
\hline LAKE MUNSON \#7 MIDDLE OF SMALL C & 22030039 & 1 & 302219 & 841816 & LAKE \\
\hline LAKE MUNSON \#8 50 YDS W OF BOAT DOCK & 22030040 & 4 & 302213 & 841811 & LAKE \\
\hline LAKE MUNSON \#9 MID COVE CORN L & 22030041 & 1 & 302158 & 841815 & LAKE \\
\hline LAKE MUNSON 12 DRAIN DITCH AT SR 61 & 22030044 & 4 & 302130 & 841815 & STREAM \\
\hline LAKE MUNSON NEAR TALLAHASSEE SITE 101 & 302203084180900 & 1 & 302203 & 841809 & LAKE \\
\hline LAKE MUNSON NEAR TALLAHASSEE SITE 102 & 302158084180700 & 1 & 302158 & 841807 & LAKE \\
\hline LAKE MUNSON NEAR TALLAHASSEE SITE 103 & 302154084180500 & 1 & 302154 & 841805 & LAKE \\
\hline LAKE MUNSON NEAR TALLAHASSEE SITE 104 & 302204084181600 & 1 & 302204 & 841816 & LAKE \\
\hline LAKE MUNSON NEAR TALLAHASSEE SITE 105 & 302207084181400 & 1 & 302207 & 841814 & LAKE \\
\hline LAKE MUNSON NEAR TALLAHASSEE SITE 107 & 302232084183500 & 1 & 302232 & 841835 & LAKE \\
\hline LAKE MUNSON NEAR TALLAHASSEE SITE 109 & 302204084183800 & 1 & 302204 & 841838 & LAKE \\
\hline LAKE MUNSON NEAR TALLAHASSEE SITE 110 & 302145084185000 & 1 & 302145 & 841850 & LAKE \\
\hline LAKE MUNSON NEAR TALLAHASSEE SITE 111 & 302144084184800 & 1 & 302144 & 841848 & LAKE \\
\hline LAKE MUNSON NEAR TALLAHASSEE SITE 112 & 302220084184900 & 1 & 302220 & 841849 & LAKE \\
\hline LAKE MUNSON NR TALLAHASSEE & 302200084183000 & 1 & 302200 & 841830 & LAKE \\
\hline LAKE MUNSON NR TALLAHASSEE & 2327018 & 1 & 302210 & 841820 & STREAM \\
\hline LAKE OTTER-WAKULLA CO. & 303 & 3 & 300032 & 841854 & LAKE \\
\hline LAKE OVERSTREET1 IN LEON CO. & OVERSTREET 1 & 18 & 303145 & 841524 & LAKE \\
\hline LAKE OVERSTREET2 IN LEON CO. & OVERSTREET2 & 18 & 303145 & 841524 & LAKE \\
\hline LAKE OVERSTREET3 IN LEON CO. & OVERSTREET3 & 18 & 303145 & 841524 & LAKE \\
\hline LAKE PETTY GULF1 IN LEON CO. & PETTY GULF1 & 29 & 303524 & 841346 & LAKE \\
\hline LAKE PETTY GULF2 IN LEON CO. & PETTY GULF2 & 29 & 303524 & 841346 & LAKE \\
\hline LAKE PETTY GULF3 IN LEON CO. & PETTY GULF3 & 29 & 303524 & 841346 & LAKE \\
\hline LAKE SHELLY POND1 IN LEON CO. & SHELLY POND1 & 2 & 303435 & 841617 & LAKE \\
\hline LAKE SHELLY POND2 IN LEON CO. & SHELLY POND2 & 2 & 303435 & 841617 & LAKE \\
\hline LAKE SHELLY POND3 IN LEON CO. & SHELLY POND3 & 2 & 303435 & 841617 & LAKE \\
\hline LAKE SOMERSET1 IN LEON CO. & SOMERSET1 & 2 & 303426 & 841547 & LAKE \\
\hline LAKE SOMERSET2 IN LEON CO. & SOMERSET2 & 2 & 303426 & 841547 & LAKE \\
\hline LAKE SOMERSET3 IN LEON CO. & SOMERSET3 & 2 & 303426 & 841547 & LAKE \\
\hline LAKE TROUT POND1 IN LEON CO. & TROUT POND1 & 22 & 302001 & 842313 & LAKE \\
\hline LAKE TROUT POND2 IN LEON CO. & TROUT POND2 & 22 & 302001 & 842313 & LAKE \\
\hline LAKE TROUT POND3 IN LEON CO. & TROUT POND3 & 22 & 302001 & 842313 & LAKE \\
\hline LITTLE LOFTON POND & 50659 & 2 & 302142 & 842253 & LAKE \\
\hline LLOYD CREEK AB UNNAMED CREEK \# 1 & 302841084003201 & 3 & 302841 & 840032 & STREAM \\
\hline LLOYD CREEK AT LLOYD & 2326700 & 31 & 302841 & 840031 & STREAM \\
\hline LLOYD CREEK S.R.158A JEFFERSON CO. & 22030061 & 7 & 302850 & 840045 & STREAM \\
\hline
\end{tabular}


Table 4. Number of surface-water-quality samples collected at each site in the St. Marks River Basin (Continued)

\begin{tabular}{|c|c|c|c|c|c|}
\hline Site name & Station ID number & $\begin{array}{c}\text { No. of } \\
\text { samples }\end{array}$ & Latitude & Longitude & Water body type \\
\hline LOFTON PONDS & 50657 & 3 & 302121 & 842245 & LAKE \\
\hline LOFTON PONDS (SOUTH) & $3 \mathrm{~B} 3-133$ & 1 & 302112 & 842255 & LAKE \\
\hline LOST CREEK & 50652 & 3 & 301145 & 842430 & STREAM \\
\hline LOST CREEK AB COW SWAMP AT 374 & 301000084234501 & 4 & 301000 & 842345 & STREAM \\
\hline LOST CREEK AT ARRAN & 2327033 & 1 & 301117 & 842430 & STREAM \\
\hline MCBRIDE SLOUGH HWY 267 WAKULLA CO. & 22030062 & 5 & 301410 & 841620 & STREAM \\
\hline MCBRIDE SLOUGH NR CRAWFORDVILLE & 2327020 & 1 & 301210 & 841535 & STREAM \\
\hline MCBRIDES SLOUGH AT HWY 267 & 301421084161201 & 4 & 301421 & 841612 & STREAM \\
\hline $\begin{array}{l}\text { MCCORD PK POND DD AT CNTVL RD AT } \\
\text { TALLAHASSEE }\end{array}$ & 2326836 & 1 & 302809 & 841501 & STREAM \\
\hline MICCOSUKKEE ROAD AT I-10 & 302950084101601 & 7 & 302950 & 841016 & CANAL \\
\hline MING BEACH & 50612 & 13 & 302110 & 841825 & LAKE \\
\hline MING BEACH & 50613 & 13 & 302110 & 841825 & LAKE \\
\hline MING BEACH & 50622 & 107 & 302415 & 842430 & LAKE \\
\hline MING BEACH & 50623 & 15 & 302415 & 842430 & LAKE \\
\hline MING BEACH & 50624 & 106 & 302330 & 842427 & LAKE \\
\hline MING BEACH & 50625 & 15 & 302330 & 842427 & LAKE \\
\hline MING BEACH & 50626 & 105 & 302245 & 842350 & LAKE \\
\hline MING BEACH & 50627 & 15 & 302245 & 840350 & LAKE \\
\hline MING BEACH & 50632 & 107 & 302110 & 841825 & LAKE \\
\hline MING BEACH & 50633 & 14 & 302110 & 841825 & LAKE \\
\hline MISSION ROAD 0.25 MI N OF I-10 & 302858084203601 & 5 & 302858 & 842036 & CANAL \\
\hline MOORE LAKE & 50658 & 5 & 302328 & 842426 & LAKE \\
\hline MOORE LAKE & $3 \mathrm{~B} 3-176$ & 1 & 302333 & 842415 & LAKE \\
\hline MUNSON SL AB LK MUNSON NR TALLAHASSEE & 302230084185000 & 1 & 302230 & 841850 & STREAM \\
\hline MUNSON SLOUGH AT CAPITAL CIRCLE & 302314084184901 & 23 & 302314 & 841849 & STREAM \\
\hline MUNSON SLOUGH AT CAPITAL CIRCLE & 302315084184800 & 4 & 302315 & 841848 & STREAM \\
\hline MUNSON SL AT CRAWFORDVILLE HWY TALLA & 302127084181100 & 4 & 302127 & 841811 & STREAM \\
\hline $\begin{array}{l}\text { MUNSON SLOUGH AT EIGHTMILE SK NR } \\
\text { TALLAHASSEE }\end{array}$ & 301910084175500 & 2 & 301910 & 841755 & STREAM \\
\hline MUNSON SLOUGH AT HWY 319 BRIDGE & 302127084181001 & 10 & 302127 & 841810 & STREAM \\
\hline $\begin{array}{l}\text { MUNSON SLOUGH AT OAK RIDGE RD NR } \\
\text { TALLAHASSEE }\end{array}$ & 301925084180800 & 2 & 301925 & 841808 & STREAM \\
\hline $\begin{array}{l}\text { MUNSON SLOUGH AT PUMP STA NR } \\
\text { TALLAHASSEE }\end{array}$ & 302414084183000 & 3 & 302414 & 841830 & STREAM \\
\hline NATURAL BRIDGE SPRING NR WOODVILLE & 2326887 & 4 & 301706 & 840850 & SPRING \\
\hline NEWPORT SPRING & 301245084104301 & 2 & 301245 & 841043 & SPRING \\
\hline NEWPORT SPRING NR NEWPORT & 301245084104300 & 1 & 301245 & 841043 & SPRING \\
\hline NORHTEAST DD AT MICCOSUKEE RD AT TALLA & 2326838 & 27 & 302750 & 841424 & STREAM \\
\hline NORTHEAST DD AT CAPITAL CIR AT TALLA & 2326828 & 1 & 302842 & 841412 & STREAM \\
\hline NORTHEAST DD AT WEEMS ROAD AT TALLA & 2326845 & 2 & 302719 & 841321 & STREAM \\
\hline ORANGE AVENUE AT STATE HWY 373A & 302448084181800 & 8 & 302448 & 841818 & CANAL \\
\hline PANACEA MINERAL SPRINGS-A AT PANACEA & 300202084232501 & 2 & 300202 & 842325 & SPRING \\
\hline PANACEA NO 4 & 300151084235801 & 2 & 300151 & 842358 & STREAM \\
\hline PARK AVENUE 1 MI. WEST OF STATE HWY 261 & 302629084144100 & 5 & 302629 & 841441 & CANAL \\
\hline REA SWIMMING BEACH & 50614 & 13 & 302010 & 842320 & LAKE \\
\hline REA SWIMMING BEACH & 50615 & 13 & 302010 & 842320 & LAKE \\
\hline REA SWIMMING BEACH & 50628 & 116 & 302145 & 842235 & LAKE \\
\hline
\end{tabular}


Table 4. Number of surface-water-quality samples collected at each site in the St. Marks River Basin (Continued)

\begin{tabular}{|c|c|c|c|c|c|}
\hline Site name & Station ID number & $\begin{array}{c}\text { No. of } \\
\text { samples }\end{array}$ & Latitude & Longitude & Water body type \\
\hline REA SWIMMING BEACH & 50629 & 113 & 302145 & 842235 & LAKE \\
\hline REA SWIMMING BEACH & 50634 & 41 & 302010 & 842320 & LAKE \\
\hline REA SWIMMING BEACH & 50635 & 41 & 302010 & 842320 & LAKE \\
\hline RHODES SPRING NO2 NR WOODVILLE & 2326889 & 1 & 301711 & 840936 & SPRING \\
\hline RHODES SPRING NO4 NR WOODVILLE & 2326893 & 1 & 301701 & 840925 & SPRING \\
\hline RIGGINS RD AT MICCOSUKKEE RD \& DOOMAR & 302750084142400 & 5 & 302750 & 841424 & CANAL \\
\hline RIVER SINK SPRING NR IVAN & 2326997 & 18 & 301636 & 842028 & SPRING \\
\hline ROBERT POSTELL WELL NR TALLAHASSEE & 302326084184001 & 3 & 302326 & 841840 & STREAM \\
\hline ROBERTS AVENUE BRIDGE AT MABRY ST & 302546084194600 & 13 & 302546 & 841946 & CANAL \\
\hline SALLY WARD; WAKULLA CO. & 301429084183901 & 2 & 301429 & 841839 & SPRING \\
\hline SAM W SMITH & 301235084184701 & 1 & 301235 & 841847 & STREAM \\
\hline SHELL POINT WELL NO.1 & 300500084182701 & 1 & 300500 & 841827 & STREAM \\
\hline SILVER LAKE, WAKULLA DISTRICT & 50619 & 10 & 302418 & 842430 & LAKE \\
\hline SINK HOLE FLOW FROM LK LAFAYETTE & 22030046 & 3 & 302711 & 841113 & LAKE \\
\hline SPRING CREEK RISE AT SPRING CREEK & 300447084195000 & 2 & 300447 & 841950 & SPRING \\
\hline ST MARKS R BUOY 59 BELOW ST MARKS & 645320 & 15 & 300700 & 840900 & STREAM \\
\hline ST MARKS R US 27 E OF TALLAHASSE & 645380 & 15 & 302500 & 840600 & STREAM \\
\hline ST MARKS R US 98 NE ST MARKS & 645360 & 15 & 301100 & 841300 & STREAM \\
\hline ST. MARKS RIVER AT FT. SAN MARCOS & 300905084123501 & 4 & 300905 & 841235 & STREAM \\
\hline ST. MARKS RIVER AT HWY 98 - NEWPORT & 301156084104201 & 8 & 301156 & 841042 & STREAM \\
\hline ST. MARKS RIVER AT US 27 & 302513084060301 & 6 & 302513 & 840603 & STREAM \\
\hline ST. MARKS RIVER NEAR NEWPORT & 2326900 & 68 & 301600 & 840900 & STREAM \\
\hline ST. MARKS SPRING NR WOODVILLE & 301632084085201 & 2 & 301632 & 840852 & SPRING \\
\hline TALL DEPT OF TRANSP STP INFL & 22031021 & 2 & 302427 & 841830 & LAKE \\
\hline TALL MABRY RD STP INFL & 22031007 & 9 & 302540 & 841935 & LAKE \\
\hline TALL SW STP SPRINGHILL RD & 22031017 & 9 & 302320 & 841930 & LAKE \\
\hline TALLAHASSEE (LK BEDFORD PLANT) & 1247BA & 12 & 302530 & 841800 & STREAM \\
\hline TALLAVANA1 GADSDEN CO. & TALLAVANA1 & 49 & 303558 & 842752 & LAKE \\
\hline TALLAVANA2 GADSDEN CO. & TALLAVANA2 & 49 & 303558 & 842752 & LAKE \\
\hline TALLAVANA3 GADSDEN CO. & TALLAVANA3 & 49 & 303558 & 842752 & LAKE \\
\hline TALLAVANA4 GADSDEN CO. & TALLAVANA4 & 40 & 303558 & 842752 & LAKE \\
\hline TALQUIN1 GADSDEN CO. & TALQUIN1 & 6 & 302623 & 843410 & LAKE \\
\hline TALQUIN2 GADSDEN CO. & TALQUIN2 & 6 & 302623 & 843410 & LAKE \\
\hline TALQUIN3 GADSDEN CO. & TALQUIN3 & 6 & 302623 & 843410 & LAKE \\
\hline THREE POLE CRK W OF SR $2600.31 \mathrm{MI}$ S OF US 90 & 22020077 & 1 & 302755 & 842416 & STREAM \\
\hline TOM GOLDEN SR WELL NR THOMAS P SMITH STP & 302251084204201 & 2 & 302251 & 842042 & STREAM \\
\hline TROUT POND & 50616 & 3 & 302003 & 842316 & LAKE \\
\hline UNNAMED LAKE NEAR TALLAHASSEE & 302722084232500 & 1 & 302722 & 842325 & LAKE \\
\hline UNNAMED STREAM & 1247B 1 & 12 & 302230 & 841900 & STREAM \\
\hline USGS LS30 & 302206084194002 & 2 & 302206 & 841940 & STREAM \\
\hline VIRGINIA AVE AT HWY 90 & 302644084174400 & 4 & 302644 & 841744 & CANAL \\
\hline W. TENNESSEE STREET AT AENON CHURCH RD & 302723084221401 & 4 & 302723 & 842214 & CANAL \\
\hline W. TENNESSEE STREET AT GEORGE BRETT & 302718084203201 & 5 & 302718 & 842032 & CANAL \\
\hline WAKULLA R US 98 NE ST MARKS & 645340 & 15 & 301000 & 841400 & STREAM \\
\hline WAKULLA R. 100 YDS ABOVE BOGGY BR & 22030023 & 1 & 300950 & 841331 & STREAM \\
\hline WAKULLA RIVER AB ST MARKS R AT HWY 61 & 301249084154201 & 11 & 301249 & 841542 & STREAM \\
\hline WAKULLA RIVER AT US 98 & 301032084144201 & 8 & 301032 & 841442 & STREAM \\
\hline
\end{tabular}


Table 4. Number of surface-water-quality samples collected at each site in the St. Marks River Basin (Continued)

\begin{tabular}{lccccc}
\hline \multicolumn{1}{c}{ Site name } & Station ID number & $\begin{array}{c}\text { No. of } \\
\text { samples }\end{array}$ & Latitude & Longitude & Water body type \\
\hline WAKULLA SPRING NR CRAWFORDVILLE & 2327000 & 296 & 301405 & 841805 & SPRING \\
WARD CREEK AB LAKE MICCOSUKEE & 303620083534101 & 3 & 303620 & 835341 & STREAM \\
WEEMS ROAD NEAR HWY 90 & 302719084132100 & 10 & 302719 & 841321 & CANAL \\
WOLF CR HWY 158 SE MONTICELLO & 645460 & 15 & 303000 & 835800 & STREAM \\
\hline \multicolumn{1}{c}{ TOTAL NUMBER OF SITES } & 277 & & & & \\
$\quad$ TOTAL NUMBER OF SAMPLES & & 4,591 & & & \\
\hline
\end{tabular}


Table 5. Number of chemical screening tests that were performed for surface-water-quality data from selected SWAMP sites, and the period of record for water-quality samples collected from each site

[DSSCRAT denotes ratio of dissolved solids to specific conductance; ANSCRAT denotes ratio of sum of anions to specific conductance; CATSCRAT denotes ratio of sum of cations to specific conductance; CBE denotes ionic charge balance error]

\begin{tabular}{|c|c|c|c|c|c|c|}
\hline \multirow{2}{*}{$\begin{array}{l}\text { Site } \\
\text { No. }\end{array}$} & \multirow{2}{*}{$\begin{array}{c}\text { Total } \\
\text { number of } \\
\text { samples }\end{array}$} & \multicolumn{4}{|c|}{ Number of samples screened for } & \multirow{2}{*}{ Period of record for site } \\
\hline & & DSSCRAT & CATSCRAT & ANSCRAT & CBE & \\
\hline \multicolumn{7}{|c|}{ Basin 1} \\
\hline 12 & 97 & 0 & 0 & 0 & 0 & 03-20-1968 thru 03-09-1997 \\
\hline 13 & 11,004 & 137 & 331 & 36 & 36 & 01-10-1952 thru 04-30-1997 \\
\hline 14 & 280 & 21 & 21 & 0 & 0 & 04-04-1966 thru 05-13-1996 \\
\hline 15 & 68 & 3 & 3 & 0 & 0 & 06-02-1966 thru 01-05-1997 \\
\hline 16 & 158 & 0 & 0 & 0 & 0 & 03-10-1971 thru 03-09-1997 \\
\hline 17 & 104 & 0 & 0 & 0 & 0 & 10-18-1971 thru 03-23-1997 \\
\hline 18 & 57 & 9 & 9 & 0 & 0 & 05-12-1966 thru 03-13-1996 \\
\hline 19 & 34 & 0 & 0 & 0 & 0 & 03-21-1971 thru 02-23-1997 \\
\hline 82 & 47 & 0 & 0 & 0 & 0 & 05-16-1966 thru 04-06-1997 \\
\hline 83 & 141 & 25 & 70 & 1 & 1 & 01-29-1958 thru 04-06-1997 \\
\hline 84 & 34 & 0 & 0 & 0 & 0 & 08-23-1971 thru 03-13-1996 \\
\hline 85 & 12 & 0 & 0 & 0 & 0 & $04-12-1995$ thru $03-13-1996$ \\
\hline 86 & 86 & 6 & 6 & 0 & 0 & 01-14-1958 thru 04-20-1997 \\
\hline 87 & 32 & 0 & 0 & 0 & 0 & 03-21-1971 thru 02-23-1997 \\
\hline 88 & 107 & 0 & 0 & 0 & 0 & 07-20-1970 thru 03-23-1997 \\
\hline 116 & 12 & 0 & 0 & 0 & 0 & 04-12-1995 thry 09-13-1996 \\
\hline 117 & 87 & 0 & 0 & 0 & 0 & 04-29-1971 thru 05-27-1997 \\
\hline 118 & 47 & 0 & 0 & 0 & 0 & 01-16-1974 thru 04-20-1997 \\
\hline 119 & 123 & 0 & 0 & 0 & 0 & 09-25-1968 thru 03-09-1997 \\
\hline 120 & 220 & 6 & 6 & 0 & 0 & 12-31-1957 thru 03-23-1997 \\
\hline 142 & 26 & 3 & 3 & 0 & 0 & 01-19-1967 thru $12-03-1995$ \\
\hline Total & 12,776 & 210 & 449 & 37 & 37 & \\
\hline
\end{tabular}

Basin 2

\begin{tabular}{|c|c|c|c|c|c|c|}
\hline 21 & NO DATA & & & & & \\
\hline 81 & 38 & 0 & 0 & 0 & 0 & 04-12-1983 thru 02-16-1997 \\
\hline 115 & 41 & 0 & 0 & 0 & 0 & 10-07-1987 thru 05-04-1997 \\
\hline 144 & 139 & 0 & 0 & 0 & 0 & 05-22-1974 thru 04-26-1993 \\
\hline Total & 218 & 0 & 0 & 0 & 0 & \\
\hline
\end{tabular}

\section{Basin 3}

\begin{tabular}{|c|c|c|c|c|c|c|}
\hline 22 & JO DATA & & & & & \\
\hline St Marks* & 4,591 & 98 & 126 & 25 & 25 & N/A \\
\hline \multicolumn{7}{|c|}{ Basin 4} \\
\hline 10 & 50 & 0 & 0 & 0 & 0 & 01-18-1971 thru 05-13-1997 \\
\hline 11 & 37 & 1 & 2 & 0 & 0 & 05-02-1956 thru 05-14-1997 \\
\hline 42 & 91 & 0 & 0 & 0 & 0 & 01-25-1972 thru 09-09-1996 \\
\hline 43 & 95 & 11 & 11 & 8 & 8 & 10-02-1978 thru 09-06-1996 \\
\hline 44 & 75 & 19 & 19 & 0 & 0 & 06-05 1967 thru 02-02-1993 \\
\hline 45 & 491 & 13 & 13 & 0 & 0 & 02-18-1917 thru $10-17-1996$ \\
\hline
\end{tabular}


Table 5. Number of chemical screening tests that were performed for surface-water-quality data from selected SWAMP sites, and the period of record for water-quality samples collected from each site (Continued)

[DSSCRAT denotes ratio of dissolved solids to specific conductance; ANSCRAT denotes ratio of sum of anions to specific conductance; CATSCRAT denotes ratio of sum of cations to specific conductance; $\mathrm{CBE}$ denotes ionic charge balance error]

\begin{tabular}{|c|c|c|c|c|c|c|}
\hline \multirow{2}{*}{$\begin{array}{l}\text { Site } \\
\text { No. }\end{array}$} & \multirow{2}{*}{$\begin{array}{c}\text { Total } \\
\text { number of } \\
\text { samples }\end{array}$} & \multicolumn{4}{|c|}{ Number of samples screened for } & \multirow{2}{*}{ Period of record for site } \\
\hline & & DSSCRAT & CATSCRAT & ANSCRAT & CBE & \\
\hline 46 & 101 & 0 & 0 & 0 & 0 & 01-25-1966 thru 09-04-1996 \\
\hline 47 & 92 & 6 & 6 & 0 & 0 & 11-19-1957 thru 09-03-1996 \\
\hline 48 & 83 & 0 & 0 & 0 & 0 & 02-10-1989 thru 09-09-1996 \\
\hline 49 & 27 & 0 & 0 & 0 & 0 & $12-08-1970$ thru $12-12-1989$ \\
\hline 76 & 138 & 0 & 0 & 0 & 0 & 03-07-1971 thru 05-14-1997 \\
\hline 77 & 113 & 29 & 29 & 4 & 4 & N/A \\
\hline 78 & 159 & 2 & 2 & 0 & 0 & 11-15-196- thru 09-09-1996 \\
\hline 79 & 109 & 0 & 0 & 0 & 0 & 12-14-1981 thru 09-11-1996 \\
\hline 80 & 85 & 0 & 0 & 0 & 0 & 03-13-1975 thru 09-03-1996 \\
\hline 110 & 25 & 0 & 0 & 0 & 0 & 08-24-1987 thru 08-16-1989 \\
\hline 111 & 43 & 0 & 0 & 0 & 0 & 01-18-1972 thru 05-14-1997 \\
\hline 112 & 83 & 0 & 0 & 0 & 0 & 02-07-1989 thru 09-06-1995 \\
\hline 113 & 167 & 5 & 5 & 0 & 0 & 05-12-1966 thru 09-11-1996 \\
\hline 114 & 84 & 0 & 0 & 0 & 0 & 02-16-1989 thru 09-03-1996 \\
\hline 137 & 39 & 0 & 0 & 0 & 0 & 02-12-1990 thru 07-29-1996 \\
\hline 138 & 52 & 0 & 0 & 0 & 0 & 01-18-1972 thru 05-13-1997 \\
\hline 139 & 38 & 29 & 30 & 5 & 5 & 04-07-1976 thru 07-22-1996 \\
\hline 140 & 368 & 2 & 2 & 0 & 0 & 05-09-1914 thru 06-07-1994 \\
\hline 141 & 146 & 2 & 2 & 0 & 0 & 02-04-1961 thru 09-04-1996 \\
\hline 149 & 83 & 0 & 0 & 0 & 0 & 02-08-1989 thru 09-06-1996 \\
\hline Total & 2,874 & 119 & 121 & 17 & 17 & \\
\hline \multicolumn{7}{|c|}{ Basin 5} \\
\hline 1 & 131 & 0 & 0 & 0 & 0 & $10-17-1961$ thru $11-11-1996$ \\
\hline 2 & 220 & 17 & 17 & 0 & 0 & 03-12-1965 thru 05-08-1997 \\
\hline 51 & 95 & 6 & 6 & 0 & 0 & 05-19-1958 thru 04-21-1997 \\
\hline 52 & 40 & 0 & 0 & 0 & 0 & 12-01-1982 thru 03-17-1997 \\
\hline 90 & 153 & 0 & 0 & 0 & 0 & 06-17-1969 thru 05-08-1997 \\
\hline 122 & 152 & 0 & 0 & 0 & 0 & 05-22-1969 thru 05-08-1997 \\
\hline Total & 791 & 23 & 23 & 0 & 0 & \\
\hline \multicolumn{7}{|c|}{ Basin 6} \\
\hline 3 & 140 & 0 & 0 & 0 & 0 & 03-16-1971 thru 02-26-1997 \\
\hline 4 & 34 & 0 & 0 & 0 & 0 & 05-19-1976 thru 02-25-1997 \\
\hline 5 & 49 & 1 & 1 & 0 & 0 & 04-10-1947 thru 03-24-1997 \\
\hline 6 & 72 & 0 & 0 & 0 & 0 & 03-18-1973 thru 07-20-1995 \\
\hline 7 & 103 & 0 & 0 & 0 & 0 & 06-02-1970 thru 02-17-1997 \\
\hline 8 & 78 & 0 & 0 & 0 & 0 & 09-17-1968 thru 04-07-1997 \\
\hline 9 & 130 & 0 & 0 & 0 & 0 & 05-15-1974 thru 03-28-1996 \\
\hline 50 & 49 & 1 & 1 & 0 & 0 & 04-10-1947 thru 03-24-1997 \\
\hline $53 \mathrm{C}$ & 234 & 0 & 3 & 0 & 0 & 05-17-1954 thru 02-26-1997 \\
\hline 54 & 65 & 0 & 0 & 0 & 0 & 03-13-1979 thru 03-05-1997 \\
\hline 55 & 50 & 0 & 0 & 0 & 0 & $07-22-1975$ thru $02-18-1997$ \\
\hline 56 & 115 & 17 & 18 & 0 & 0 & 10-21-1964 thru 02-04-1997 \\
\hline
\end{tabular}


Table 5. Number of chemical screening tests that were performed for surface-water-quality data from selected SWAMP sites, and the period of record for water-quality samples collected from each site (Continued)

[DSSCRAT denotes ratio of dissolved solids to specific conductance; ANSCRAT denotes ratio of sum of anions to specific conductance; CATSCRAT denotes ratio of sum of cations to specific conductance; $\mathrm{CBE}$ denotes ionic charge balance error]

\begin{tabular}{|c|c|c|c|c|c|c|}
\hline \multirow{2}{*}{$\begin{array}{l}\text { Site } \\
\text { No. }\end{array}$} & \multirow{2}{*}{$\begin{array}{c}\text { Total } \\
\text { number of } \\
\text { samples }\end{array}$} & \multicolumn{4}{|c|}{ Number of samples screened for } & \multirow{2}{*}{ Period of record for site } \\
\hline & & DSSCRAT & CATSCRAT & ANSCRAT & CBE & \\
\hline 57 & 28 & 0 & 0 & 0 & 0 & 12-13-1983 thru 03-03-1997 \\
\hline 58 & 188 & 0 & 1 & 0 & 0 & 11-21-1979 thru 02-05-1996 \\
\hline 89 & 177 & 24 & 24 & 0 & 0 & 04-30-1956 thru 02-24-1997 \\
\hline 91 & 84 & 11 & 11 & 1 & 1 & 04-26-1956 thru 03-31-1997 \\
\hline 92 & 9 & 0 & 0 & 0 & 0 & 06-26-1995 thru 02-17-1997 \\
\hline 93 & 30 & 0 & 0 & 0 & 0 & 02-24-1976 thru 02-18-1997 \\
\hline 94 & 197 & 0 & 0 & 0 & 0 & 09-17-1968 thru 04-07-1997 \\
\hline 95 & 59 & 0 & 0 & 0 & 0 & 01-21-1971 thru 01-06-1997 \\
\hline 121 & 482 & 23 & 62 & 2 & 2 & 05-13-1966 thru 08-14-1996 \\
\hline \multirow[t]{2}{*}{123} & 150 & & & & & Part 1: 02-10-71 thru 05-20-96 \\
\hline & 329 & & & & & Part 2: 01-28-91 thru 05-17-94 \\
\hline 124 & 98 & 1 & 1 & 0 & 0 & 06-01-1970 thru $02-17-1997$ \\
\hline 125 & 101 & 0 & 0 & 0 & 0 & 07-19-1971 thru 02-19-1997 \\
\hline 126 & 73 & 0 & 0 & 0 & 0 & 11-09-1977 thru 04-22-1997 \\
\hline 127 & 23 & 0 & 0 & 0 & 0 & 08-10-1987 thru 05-15-1995 \\
\hline 143 & 24 & 0 & 0 & 0 & 0 & 02-07-1978 thru 02-06-1996 \\
\hline Total & 3,171 & 78 & 122 & 3 & 3 & \\
\hline \multicolumn{7}{|c|}{ Basin 7} \\
\hline 24 & 127 & 0 & 0 & 0 & 0 & 03-25-1956 thru 11-14-1995 \\
\hline 26 & NO DATA & & & & & \\
\hline 25 & 83 & 0 & 0 & 0 & 0 & $10-30-1973$ thru $05-15-1996$ \\
\hline 28 & 217 & 0 & 0 & 0 & 0 & 03-28-1973 thru 06-06-1996 \\
\hline 29 & 164 & 0 & 0 & 0 & 0 & 01-03-1951 thru 06-60-1996 \\
\hline 32 & 133 & 0 & 0 & 0 & 0 & 04-22-1971 thru 06-12-1996 \\
\hline 33 & 189 & 0 & 0 & 0 & 0 & 07-25-1966 thru $12-07-1994$ \\
\hline 34 & 550 & 0 & 0 & 0 & 0 & 01-27-1982 thru $12-13-1995$ \\
\hline 35 & 247 & 5 & 8 & 0 & 0 & 01-15-1934 thru 02-22-1995 \\
\hline 36 & 253 & 0 & 0 & 0 & 0 & 05-12-1976 thru $11-29-1995$ \\
\hline 38 & 77 & 6 & 19 & 0 & 0 & 03-09-1964 thru 10-17-1995 \\
\hline 65 & 176 & 1 & 2 & 0 & 0 & 06-12-1962 thru 06-12-1996 \\
\hline 66 & 6 & 0 & 0 & 0 & 0 & 08-15-1977 thru 09-24-1996 \\
\hline 67 & 12 & 0 & 0 & 0 & 0 & 07-12-1995 thru 09-25-1996 \\
\hline 68 & 189 & 0 & 0 & 0 & 0 & 03-23-1992 thru 09-24-1996 \\
\hline 69 & 238 & 0 & 0 & 0 & 0 & $12-09-1981$ thru $06-19-1996$ \\
\hline 70 & 82 & 33 & 48 & 1 & 1 & 03-25-1965 thru $11-14-1995$ \\
\hline $71 \mathrm{C}$ & 102 & 0 & 0 & 0 & 0 & 09-26-1989 thru 06-18-1996 \\
\hline 72 & 270 & 0 & 0 & 0 & 0 & 01-06-1988 thru 06-18-1996 \\
\hline 73 & 7 & 54 & 71 & 1 & 1 & 05-03-1956 thru 09-20-1995 \\
\hline 74 & 11 & 0 & 0 & 0 & 0 & 09-16-1992 thru 11-14-1995 \\
\hline 101 & 11 & 0 & 0 & 0 & 0 & 09-16-1992 thru 08-21-1996 \\
\hline 102 & 4 & 0 & 0 & 0 & 0 & 04-02-1992 thru 09-24-1996 \\
\hline 103 & 249 & 0 & 0 & 0 & 0 & 07-12-1995 thru 09-25-1996 \\
\hline
\end{tabular}


Table 5. Number of chemical screening tests that were performed for surface-water-quality data from selected SWAMP sites, and the period of record for water-quality samples collected from each site (Continued)

[DSSCRAT denotes ratio of dissolved solids to specific conductance; ANSCRAT denotes ratio of sum of anions to specific conductance; CATSCRAT denotes ratio of sum of cations to specific conductance; $\mathrm{CBE}$ denotes ionic charge balance error]

\begin{tabular}{|c|c|c|c|c|c|c|}
\hline \multirow{2}{*}{$\begin{array}{l}\text { Site } \\
\text { No. }\end{array}$} & \multirow{2}{*}{$\begin{array}{c}\text { Total } \\
\text { number of } \\
\text { samples }\end{array}$} & \multicolumn{4}{|c|}{ Number of samples screened for } & \multirow{2}{*}{ Period of record for site } \\
\hline & & DSSCRAT & CATSCRAT & ANSCRAT & CBE & \\
\hline 104 & 24 & 0 & 0 & 0 & 0 & 12-12-1966 thru 12-13-1994 \\
\hline 105 & 553 & 1 & 2 & 0 & 0 & 02-03-1962 thru 11-14-1995 \\
\hline 106 & 19 & 0 & 0 & 0 & 0 & $11-13-1950$ thru $06-19-1996$ \\
\hline 107 & 126 & 0 & 0 & 0 & 0 & 03-23-1992 thru 09-12-1996 \\
\hline 108 & 6 & 0 & 0 & 0 & 0 & 06-27-1991 thru 10-02-1996 \\
\hline 109 & 97 & 0 & 0 & 0 & 0 & 06-26-1995 thru 09-23-1996 \\
\hline 132 & 553 & 0 & 0 & 0 & 0 & 04-28-1970 thru 07-12-1995 \\
\hline 134 & 55 & 0 & 0 & 0 & 0 & $11-13-1950$ thru 06-19-1996 \\
\hline 135 & 86 & 4 & 4 & 0 & 0 & 05-19-1966 thru 09-19-1996 \\
\hline 136 & 354 & 2 & 2 & 0 & 0 & 05-28-1918 thru 09-18-1996 \\
\hline Total & 5,270 & 106 & 156 & 2 & 2 & \\
\hline \multicolumn{7}{|c|}{ Basin 8} \\
\hline 23 & 1358 & 0 & 0 & 0 & 0 & 11-06-1972 thru 02-14-1996 \\
\hline 27 & 83 & 4 & 16 & 0 & 0 & 08-09-1971 thru 03-04-1996 \\
\hline 30 & 273 & 0 & 0 & 0 & 0 & 01-17-1973 thru 05-16-1996 \\
\hline 31 & 11 & 2 & 2 & 1 & 1 & 05-19-1972 thru 01-09-1996 \\
\hline 39 & 420 & 1 & 1 & 0 & 0 & 01-17-1973 thru 09-27-1994 \\
\hline 40 & 73 & 93 & 127 & 38 & 38 & 10-05-1961 thru 05-14-1996 \\
\hline 41 & 1383 & 0 & 0 & 0 & 0 & $10-03-1984$ thru $12-04-1995$ \\
\hline 59 & 606 & 6 & 21 & 0 & 0 & 08-09-1971 thru 03-04-1996 \\
\hline 60 & 525 & 0 & 0 & 0 & 0 & 01-13-1969 thru 02-14-1996 \\
\hline 61 & 323 & 14 & 20 & 0 & 0 & 09-25-1948 thru 08-08-1996 \\
\hline 62 & 19 & 0 & 0 & 0 & 0 & 11-06-1972 thru 02-14-1996 \\
\hline 63 & 744 & 0 & 0 & 0 & 0 & 07-25-1972 thru 10-24-1995 \\
\hline $64 \mathrm{C}$ & 277 & 0 & 10 & 0 & 0 & 02-12-1941 thru 08-08-1996 \\
\hline 96 & 11 & 59 & 62 & 0 & 0 & 02-08-1963 thru 02-07-1996 \\
\hline 97 & 671 & 0 & 0 & 0 & 0 & 03-17-1987 thru 08-08-1996 \\
\hline 98 & 174 & 0 & 0 & 0 & 0 & $11-06-1972$ thru $02-14-1996$ \\
\hline 99 & 22 & 25 & 25 & 0 & 0 & $10-26-1970$ thru $12-19-1988$ \\
\hline 100 & 31 & 2 & 2 & 1 & 1 & 09-20-1972 thru 08-27-1996 \\
\hline 128 & 507 & 0 & 0 & 0 & 0 & 07-14-1977 thru 04-22-1997 \\
\hline 129 & 204 & 0 & 0 & 0 & 0 & 11-06-1972 thru 11-16-1993 \\
\hline 130 & 341 & 40 & 45 & 0 & 0 & $11-27-1965$ thru $07-10-1991$ \\
\hline 131 & 79 & 5 & 10 & 0 & 0 & 08-09-1945 thru 08-27-1996 \\
\hline $133 \mathrm{C}$ & 192 & 0 & 0 & 0 & 0 & 02-15-1989 thru 01-10-1996 \\
\hline 145 & 510 & 4 & 5 & 0 & 0 & 03-16-1970 thru 02-06-1996 \\
\hline 146 & 143 & 8 & 22 & 0 & 0 & 08-09-1971 thru 02-06-1996 \\
\hline 147 & 799 & 21 & 27 & 2 & 2 & $11-03-1959$ thru $03-25-1997$ \\
\hline 148 & NO DATA & & & & & \\
\hline 150 & & 104 & 126 & 15 & 15 & 11-20-1954 thru 10-03-1996 \\
\hline Total & 9779 & 388 & 521 & 57 & 57 & \\
\hline
\end{tabular}


Table 6. Summary statistics for chemical screening tests of water-quality data from selected SWAMP sites [N denotes number of samples; NP denotes number of samples that passed screening criteria (see text); P denotes percentage of samples that passed screening criteria; DSSCRAT denotes ratio of dissolved solids to specific conductance, in $\mu \mathrm{S} / \mathrm{cm}$; CATSCRAT denotes ratio of cation sum in milliequivalents per liter to specific conductance; ANSCRAT denotes ratio of anion sum in milliequivalents per liter to specific conductance; and CBE denotes charge balance error in percent; --- denotes not calculated due to an insufficient number of samples]

\begin{tabular}{|c|c|c|c|c|c|c|c|c|}
\hline Screening test & $\mathbf{N}$ & NP & $\mathbf{P}$ & Minimum & Maximum & Mean & $\begin{array}{l}\text { Standard } \\
\text { deviation }\end{array}$ & Median \\
\hline \multicolumn{9}{|c|}{ Basin 1} \\
\hline DSSCRAT & 208 & 167 & 80 & 0.45 & 1.13 & 0.66 & 0.13 & 0.62 \\
\hline CATSCRAT & 446 & 417 & 93 & 0.09 & 1.32 & 0.93 & 0.10 & 0.94 \\
\hline ANSCRAT & 37 & 23 & 62 & 0.46 & 1.09 & 0.82 & 0.14 & 0.83 \\
\hline $\mathrm{CBE}$ & 37 & 31 & 84 & -5.56 & 33.9 & 6.71 & 8.26 & 4.89 \\
\hline \multicolumn{9}{|c|}{ Basin 3} \\
\hline DSSCRAT & 98 & 69 & 70 & 0.41 & 0.74 & 0.57 & 0.05 & 0.56 \\
\hline CATSCRAT & 126 & 120 & 95 & 0.76 & 1.27 & 1.03 & 0.08 & 1.03 \\
\hline ANSCRAT & 25 & 22 & 88 & 0.77 & 1.00 & 0.87 & 0.06 & 0.88 \\
\hline $\mathrm{CBE}$ & 25 & 16 & 64 & 4.33 & 14.2 & 9.28 & 2.50 & 8.69 \\
\hline \multicolumn{9}{|c|}{ Basin 4} \\
\hline DSSCRAT & 119 & 75 & 63 & 0.41 & 47.6 & 1.57 & 6.13 & 0.58 \\
\hline CATSCRAT & 121 & 84 & 69 & 0.46 & 97.2 & 2.83 & 11.8 & 1.05 \\
\hline ANSCRAT & 17 & 8 & 47 & 0.65 & 1.29 & 0.87 & 0.16 & 0.84 \\
\hline $\mathrm{CBE}$ & 17 & 10 & 59 & -36.4 & 16.2 & 2.7 & 14.0 & 7.43 \\
\hline \multicolumn{9}{|c|}{ Basin 5} \\
\hline DSSCRAT & 23 & 12 & 52 & 0.26 & 0.76 & 0.51 & 0.14 & 0.55 \\
\hline CATSCRAT & 23 & 16 & 70 & 0.41 & 1.24 & 0.85 & 0.25 & 0.90 \\
\hline ANSCRAT & --- & --- & --- & --- & -- & --- & --- & --- \\
\hline CBE & --- & --- & --- & --- & --- & --- & --- & --- \\
\hline \multicolumn{9}{|c|}{ Basin 6} \\
\hline DSSCRAT & 78 & 46 & 59 & 0.48 & 32.2 & 1.60 & 5.26 & 0.56 \\
\hline CATSCRAT & 122 & 113 & 93 & 0.80 & 787 & 8.76 & 71.5 & 1.04 \\
\hline ANSCRAT & 3 & 2 & 67 & 0.77 & 1.07 & 0.89 & 0.16 & 0.82 \\
\hline $\mathrm{CBE}$ & 3 & 0 & 0 & 11.5 & 15.7 & 13.6 & 2.1 & 13.4 \\
\hline \multicolumn{9}{|c|}{ Basin 7} \\
\hline DSSCRAT & 107 & 60 & 56 & 0.05 & 29.2 & 1.35 & 4.60 & 0.57 \\
\hline CATSCRAT & 157 & 143 & 91 & 0.23 & 52.8 & 1.99 & 7.04 & 1.01 \\
\hline ANSCRAT & 2 & 1 & 50 & 0.72 & 0.81 & 0.76 & --- & 0.76 \\
\hline $\mathrm{CBE}$ & 2 & 0 & 0 & 11.3 & 13.8 & 12.5 & 1.77 & 12.5 \\
\hline \multicolumn{9}{|c|}{ Basin 8} \\
\hline DSSCRAT & 388 & 197 & 51 & 0.20 & 1,870 & 5.45 & 94.7 & 0.55 \\
\hline CATSCRAT & 533 & 490 & 92 & 0.36 & 3,350 & 7.36 & 145 & 0.98 \\
\hline ANSCRAT & 62 & 43 & 69 & 0.65 & 2.80 & 0.99 & 0.37 & 0.89 \\
\hline CBE & 62 & 54 & 87 & -15.4 & 20.3 & 2.82 & 6.20 & 4.34 \\
\hline \multicolumn{9}{|c|}{ All basins } \\
\hline DSSCRAT & , 1021 & 626 & 61 & 0.05 & 1,870 & 2.72 & 58.5 & 0.57 \\
\hline CATSCRAT & 1,528 & 1,383 & 91 & 0.09 & 3,350 & 4.10 & 88.2 & 0.98 \\
\hline ANSCRAT & 146 & 99 & 68 & 0.46 & 2.80 & 0.91 & 0.27 & 0.86 \\
\hline $\mathrm{CBE}$ & 146 & 111 & 76 & -36.4 & 33.9 & 5.25 & 8.02 & 5.98 \\
\hline
\end{tabular}


Table 7. Number of samples from selected SWAMP sites with $\mathrm{pH}$ and specific-conductance (SC) data flagged for anomalously low or high values

\begin{tabular}{|c|c|c|c|c|c|c|c|}
\hline \multirow{2}{*}{$\begin{array}{l}\text { Site } \\
\text { No. }\end{array}$} & \multirow{2}{*}{$\begin{array}{c}\text { Total } \\
\text { number of } \\
\text { samples }\end{array}$} & \multirow{2}{*}{$\begin{array}{c}\text { Total } \\
\text { number of } \\
\text { pH samples }\end{array}$} & \multicolumn{2}{|c|}{ Number of flags } & \multirow{2}{*}{$\begin{array}{c}\text { Total } \\
\text { number of } \\
\text { SC samples }\end{array}$} & \multicolumn{2}{|c|}{ Number of flags } \\
\hline & & & $\begin{array}{c}\text { Field pH } \\
\text { P_400 }\end{array}$ & $\begin{array}{c}\text { Lab pH } \\
\text { P_403 }\end{array}$ & & $\begin{array}{c}\text { Lab SC } \\
\text { P_94 }\end{array}$ & $\begin{array}{c}\text { Field SC } \\
\text { P_95 }\end{array}$ \\
\hline \multicolumn{8}{|c|}{ Basin 1} \\
\hline 12 & 97 & 79 & 0 & 0 & 50 & 1 & 0 \\
\hline 13 & 11,004 & 4,686 & 1 & 0 & 1,879 & 1 & 2 \\
\hline 14 & 280 & 232 & 0 & 0 & 183 & 2 & 1 \\
\hline 15 & 68 & 61 & 0 & 0 & 45 & 0 & 0 \\
\hline 16 & 158 & 106 & 0 & 0 & 83 & 0 & 0 \\
\hline 17 & 104 & 96 & 0 & 0 & 46 & 0 & 0 \\
\hline 18 & 57 & 44 & 0 & 0 & 36 & 0 & 0 \\
\hline 19 & 34 & 32 & 1 & 0 & 22 & 0 & 0 \\
\hline 82 & 47 & 46 & 0 & 0 & 45 & 0 & 0 \\
\hline 83 & 141 & 130 & 0 & 0 & 107 & 1 & 0 \\
\hline 84 & 34 & 31 & 0 & 0 & 18 & 0 & 0 \\
\hline 85 & 12 & 11 & 0 & 0 & 11 & 0 & 0 \\
\hline 86 & 86 & 79 & 0 & 0 & 50 & 0 & 0 \\
\hline 87 & 32 & 31 & 0 & 0 & 23 & 0 & 0 \\
\hline 88 & 107 & 99 & 0 & 0 & 47 & 1 & 0 \\
\hline 116 & 12 & 11 & 0 & 0 & 11 & 0 & 0 \\
\hline 117 & 87 & 69 & 0 & 0 & 58 & 0 & 0 \\
\hline 118 & 47 & 34 & 0 & 0 & 34 & 0 & 0 \\
\hline 119 & 123 & 91 & 0 & 0 & 56 & 0 & 0 \\
\hline 120 & 220 & 168 & 0 & 0 & 69 & 0 & 1 \\
\hline 142 & 26 & 23 & 0 & 0 & 23 & 0 & 0 \\
\hline Total & 12,776 & 6,159 & 2 & 0 & 2,896 & 6 & 4 \\
\hline \multicolumn{8}{|c|}{ Basin 2} \\
\hline 21 & NO DATA & & & & & & \\
\hline 81 & 38 & 36 & 0 & 0 & 27 & 0 & 0 \\
\hline 115 & 41 & 40 & 0 & 0 & 31 & 0 & 0 \\
\hline 144 & 151 & 104 & 0 & 0 & 48 & 0 & 0 \\
\hline Total & 230 & 180 & 0 & 0 & 106 & 0 & 0 \\
\hline \multicolumn{8}{|c|}{ Basin 3} \\
\hline 22 & NO DATA & & & & & & \\
\hline St Marks* & 4,591 & \multicolumn{3}{|c|}{ Not analyzed } & \multicolumn{3}{|c|}{ Not analyzed } \\
\hline Marks Riv & er basin sites, & see table 4. & & & & & \\
\hline \multicolumn{8}{|c|}{ Basin 4} \\
\hline 10 & 50 & 48 & 0 & 0 & 39 & 0 & 0 \\
\hline 11 & 37 & 33 & 0 & 0 & 35 & 0 & 0 \\
\hline 42 & 91 & 89 & 0 & 0 & 88 & 0 & 0 \\
\hline 43 & 95 & 88 & 0 & 0 & 88 & 0 & 0 \\
\hline 44 & 75 & 60 & 0 & 0 & 62 & 0 & 3 \\
\hline 45 & 491 & 111 & 0 & 0 & 110 & 0 & 1 \\
\hline 46 & 101 & 100 & 1 & 1 & 100 & 0 & 0 \\
\hline 47 & 92 & 90 & 0 & 0 & 90 & 0 & 0 \\
\hline
\end{tabular}


Table 7. Number of samples from selected SWAMP sites with $\mathrm{pH}$ and specific-conductance (SC) data flagged for anomalously low or high values (Continued)

\begin{tabular}{|c|c|c|c|c|c|c|c|}
\hline \multirow{2}{*}{$\begin{array}{l}\text { Site } \\
\text { No. }\end{array}$} & \multirow{2}{*}{$\begin{array}{c}\text { Total } \\
\text { number of } \\
\text { samples }\end{array}$} & \multirow{2}{*}{$\begin{array}{c}\text { Total } \\
\text { number of } \\
\text { pH samples }\end{array}$} & \multicolumn{2}{|c|}{ Number of flags } & \multirow{2}{*}{$\begin{array}{c}\text { Total } \\
\text { number of } \\
\text { SC samples }\end{array}$} & \multicolumn{2}{|c|}{ Number of flags } \\
\hline & & & $\begin{array}{l}\text { Field pH } \\
\text { P_400 }\end{array}$ & $\begin{array}{c}\text { Lab pH } \\
\text { P_403 }\end{array}$ & & $\begin{array}{c}\text { Lab SC } \\
\text { P_94 }\end{array}$ & $\begin{array}{c}\text { Field SC } \\
\text { P_95 }\end{array}$ \\
\hline 48 & 83 & 82 & 0 & 0 & 82 & 0 & 0 \\
\hline 49 & 27 & 25 & 0 & 0 & 13 & 0 & 0 \\
\hline 76 & 138 & 120 & 0 & 0 & 107 & 0 & 3 \\
\hline 77 & 113 & 110 & 0 & 0 & 112 & 0 & 0 \\
\hline 78 & 159 & 157 & 0 & 0 & 156 & 0 & 0 \\
\hline 79 & 109 & 106 & 0 & 0 & 107 & 0 & 0 \\
\hline 80 & 85 & 83 & 0 & 0 & 84 & 0 & 0 \\
\hline 110 & 25 & 24 & 0 & 0 & 24 & 0 & 0 \\
\hline 111 & 43 & 39 & 0 & 0 & 37 & 0 & 1 \\
\hline 112 & 83 & 81 & 0 & 0 & 82 & 0 & 0 \\
\hline 113 & 167 & 129 & 0 & 0 & 132 & 0 & 2 \\
\hline 114 & 84 & 81 & 0 & 0 & 82 & 0 & 0 \\
\hline 137 & 39 & 38 & 0 & 0 & 38 & 0 & 0 \\
\hline 138 & 52 & 46 & 0 & 0 & 46 & 0 & 2 \\
\hline 139 & 38 & 33 & 0 & 0 & 36 & 0 & 0 \\
\hline 140 & 368 & 13 & 0 & 0 & 11 & 0 & 0 \\
\hline 141 & 146 & 91 & 0 & 0 & 102 & 0 & 0 \\
\hline 149 & 83 & 82 & 0 & 0 & 82 & 0 & 0 \\
\hline Total & 2,874 & 1,959 & 1 & 1 & 1,945 & 0 & 12 \\
\hline \multicolumn{8}{|c|}{ Basin 6} \\
\hline 1 & 131 & 106 & 0 & 0 & 111 & 2 & 2 \\
\hline 2 & 220 & 152 & 1 & 0 & 170 & 0 & 1 \\
\hline 51 & 95 & 59 & 1 & 0 & 53 & 0 & 0 \\
\hline 52 & 40 & 27 & 0 & 0 & 35 & 0 & 0 \\
\hline 90 & 153 & 129 & 0 & 0 & 129 & 0 & 0 \\
\hline 122 & 152 & 131 & 0 & 0 & 130 & 0 & 0 \\
\hline Total & 791 & 604 & 2 & 0 & 628 & 2 & 3 \\
\hline \multicolumn{8}{|c|}{ Basin 7} \\
\hline 3 & 140 & 115 & 5 & 5 & 118 & 0 & 0 \\
\hline 4 & 34 & 25 & 0 & 0 & 25 & 0 & 0 \\
\hline 5 & 49 & 19 & 0 & 0 & 17 & 0 & 0 \\
\hline 6 & 72 & 52 & 0 & 0 & 43 & 0 & 0 \\
\hline 7 & 103 & 90 & 0 & 0 & 87 & 0 & 0 \\
\hline 8 & 78 & 67 & 0 & 0 & 66 & 0 & 0 \\
\hline 9 & 130 & 127 & 0 & 0 & 13 & 0 & 0 \\
\hline 50 & 49 & 19 & 0 & 0 & 17 & 0 & 0 \\
\hline 53 & 234 & 219 & 1 & 1 & 226 & 0 & 3 \\
\hline 54 & 65 & 57 & 2 & 0 & 58 & 1 & 0 \\
\hline 55 & 50 & 30 & 0 & 0 & 31 & 0 & 0 \\
\hline 56 & 115 & 72 & 0 & 0 & 68 & 0 & 0 \\
\hline 57 & 28 & 17 & 0 & 0 & 17 & 0 & 0 \\
\hline 58 & 188 & 185 & 0 & 0 & 186 & 0 & 0 \\
\hline 89 & 177 & 44 & 0 & 0 & 148 & 0 & 5 \\
\hline 91 & 84 & 46 & 0 & 0 & 53 & 0 & 0 \\
\hline
\end{tabular}


Table 7. Number of samples from selected SWAMP sites with $\mathrm{pH}$ and specific-conductance (SC) data flagged for anomalously low or high values (Continued)

\begin{tabular}{|c|c|c|c|c|c|c|c|}
\hline \multirow{2}{*}{$\begin{array}{l}\text { Site } \\
\text { No. }\end{array}$} & \multirow{2}{*}{$\begin{array}{c}\text { Total } \\
\text { number of } \\
\text { samples }\end{array}$} & \multirow{2}{*}{$\begin{array}{c}\text { Total } \\
\text { number of } \\
\text { pH samples }\end{array}$} & \multicolumn{2}{|c|}{ Number of flags } & \multirow{2}{*}{$\begin{array}{c}\text { Total } \\
\text { number of } \\
\text { SC samples }\end{array}$} & \multicolumn{2}{|c|}{ Number of flags } \\
\hline & & & $\begin{array}{c}\text { Field pH } \\
\text { P_400 }\end{array}$ & $\begin{array}{c}\text { Lab pH } \\
\text { P_403 }\end{array}$ & & $\begin{array}{c}\text { Lab SC } \\
\text { P_94 }\end{array}$ & $\begin{array}{c}\text { Field SC } \\
\text { P_95 }\end{array}$ \\
\hline 92 & 9 & 2 & 0 & 0 & 2 & 0 & 0 \\
\hline 93 & 30 & 22 & 0 & 0 & 22 & 0 & 0 \\
\hline 94 & 197 & 172 & 0 & 0 & 170 & 0 & 0 \\
\hline 95 & 59 & 58 & 0 & 0 & 31 & 0 & 0 \\
\hline 121 & 482 & 281 & 18 & 0 & 415 & 5 & 5 \\
\hline 123 & 150 & 131 & 0 & 0 & 109 & 0 & 1 \\
\hline 124 & 329 & 275 & 0 & 0 & 251 & 0 & 8 \\
\hline 125 & 98 & 71 & 0 & 0 & 60 & 0 & 0 \\
\hline 126 & 101 & 87 & 0 & 0 & 88 & 0 & 0 \\
\hline 127 & 73 & 66 & 0 & 0 & 68 & 0 & 0 \\
\hline 143 & 23 & 21 & 0 & 0 & 21 & 0 & 0 \\
\hline Total & 3,147 & 2,370 & 26 & 6 & 2,410 & 6 & 22 \\
\hline \multicolumn{8}{|c|}{ Basin 7} \\
\hline 24 & 24 & 0 & 0 & 0 & 12 & 0 & 0 \\
\hline 25 & 127 & 122 & 1 & 0 & 123 & 0 & 0 \\
\hline 26 & NO DATA & & & & & & \\
\hline 28 & 83 & 60 & 0 & 0 & 60 & 0 & 0 \\
\hline 29 & 217 & 173 & 1 & 0 & 167 & 0 & 0 \\
\hline 32 & 164 & 143 & 1 & 0 & 143 & 0 & 0 \\
\hline 33 & 133 & 66 & 1 & 0 & 60 & 5 & 0 \\
\hline 34 & 189 & 172 & 0 & 0 & 173 & 5 & 1 \\
\hline 35 & 550 & 181 & 0 & 1 & 222 & 0 & 9 \\
\hline 36 & 247 & 241 & 0 & 0 & 242 & 3 & 2 \\
\hline 38 & 253 & 114 & 0 & 0 & 153 & 0 & 0 \\
\hline 65 & 77 & 57 & 0 & 0 & 56 & 1 & 2 \\
\hline 66 & 176 & 156 & 0 & 0 & 57 & 0 & 0 \\
\hline 67 & 6 & 0 & 0 & 0 & 2 & 0 & 0 \\
\hline 68 & 12 & 4 & 0 & 0 & 7 & 0 & 0 \\
\hline 69 & 189 & 172 & 0 & 0 & 173 & 5 & 6 \\
\hline 70 & 238 & 175 & 1 & 0 & 216 & 0 & 2 \\
\hline 71 & 82 & 81 & 4 & 0 & 79 & 2 & 0 \\
\hline 72 & 102 & 102 & 0 & 0 & 95 & 0 & 0 \\
\hline 73 & 270 & 180 & 2 & 0 & 249 & 0 & 4 \\
\hline 74 & 7 & 0 & 0 & 0 & 6 & 0 & 0 \\
\hline 101 & 11 & 2 & 0 & 0 & 10 & 0 & 0 \\
\hline 102 & 11 & 4 & 0 & 0 & 7 & 0 & 0 \\
\hline 103 & 4 & 0 & 0 & 0 & 2 & 0 & 0 \\
\hline 104 & 249 & 235 & 0 & 0 & 134 & 0 & 1 \\
\hline 105 & 24 & 6 & 0 & 0 & 13 & 0 & 0 \\
\hline 106 & 553 & 111 & 0 & 0 & 110 & 0 & 2 \\
\hline 107 & 19 & 9 & 0 & 0 & 14 & 0 & 0 \\
\hline 108 & 126 & 5 & 0 & 0 & 10 & 0 & 0 \\
\hline 109 & 6 & 0 & 0 & 0 & 3 & 0 & 0 \\
\hline 132 & 97 & 0 & 0 & 0 & 0 & 0 & 0 \\
\hline
\end{tabular}


Table 7. Number of samples from selected SWAMP sites with $\mathrm{pH}$ and specific-conductance (SC) data flagged for anomalously low or high values (Continued)

\begin{tabular}{|c|c|c|c|c|c|c|c|}
\hline \multirow{2}{*}{$\begin{array}{l}\text { Site } \\
\text { No. }\end{array}$} & \multirow{2}{*}{$\begin{array}{c}\text { Total } \\
\text { number of } \\
\text { samples }\end{array}$} & \multirow{2}{*}{$\begin{array}{c}\text { Total } \\
\text { number of } \\
\text { pH samples }\end{array}$} & \multicolumn{2}{|c|}{ Number of flags } & \multirow{2}{*}{$\begin{array}{c}\text { Total } \\
\text { number of } \\
\text { SC samples }\end{array}$} & \multicolumn{2}{|c|}{ Number of flags } \\
\hline & & & $\begin{array}{l}\text { Field pH } \\
\text { P_400 }\end{array}$ & $\begin{array}{c}\text { Lab pH } \\
\text { P_403 }\end{array}$ & & $\begin{array}{c}\text { Lab SC } \\
\text { P_94 }\end{array}$ & $\begin{array}{c}\text { Field SC } \\
\text { P_95 }\end{array}$ \\
\hline 134 & 553 & 112 & 0 & 0 & 111 & 0 & 1 \\
\hline 135 & 55 & 26 & 0 & 0 & 51 & 0 & 0 \\
\hline 136 & 86 & 61 & 0 & 0 & 70 & 0 & 0 \\
\hline Total & 4,940 & 2,770 & 11 & 1 & 2,830 & 21 & 30 \\
\hline \multicolumn{8}{|c|}{ Basin 8} \\
\hline 23 & 354 & 332 & 1 & 0 & 309 & 9 & 0 \\
\hline 27 & 1,358 & 410 & 0 & 0 & 416 & 2 & 0 \\
\hline 30 & 83 & 65 & 0 & 0 & 69 & 0 & 0 \\
\hline 31 & 273 & 210 & 0 & 0 & 215 & 2 & 0 \\
\hline 39 & 11 & 4 & 0 & 0 & 4 & 0 & 0 \\
\hline 40 & 420 & 303 & 0 & 0 & 329 & 0 & 0 \\
\hline 41 & 73 & 28 & 0 & 0 & 28 & 3 & 0 \\
\hline 59 & 1,383 & 444 & 1 & 0 & 452 & 2 & 0 \\
\hline 60 & 606 & 378 & 5 & 0 & 360 & 6 & 0 \\
\hline 61 & 525 & 451 & 2 & 0 & 411 & 1 & 0 \\
\hline 62 & 323 & 4 & 0 & 0 & 3 & 0 & 0 \\
\hline 63 & 19 & 9 & 1 & 1 & 8 & 1 & 0 \\
\hline 64 & 744 & 704 & 1 & 0 & 668 & 8 & 3 \\
\hline 96 & 277 & 190 & 9 & 0 & 224 & 0 & 1 \\
\hline 97 & 11 & 10 & 0 & 0 & 10 & 0 & 0 \\
\hline 98 & 671 & 397 & 2 & 0 & 368 & 16 & 0 \\
\hline 99 & 174 & 105 & 0 & 0 & 148 & 0 & 0 \\
\hline 100 & 22 & 14 & 0 & 0 & 12 & 0 & 0 \\
\hline 128 & 31 & 28 & 0 & 0 & 6 & 0 & 0 \\
\hline 129 & 507 & 313 & 11 & 0 & 285 & 6 & 0 \\
\hline 130 & 204 & 64 & 0 & 0 & 79 & 0 & 1 \\
\hline 131 & 341 & 246 & 0 & 0 & 286 & 6 & 4 \\
\hline 133 & 546 & 440 & 0 & 0 & 285 & 0 & 2 \\
\hline 145 & 192 & 180 & 0 & 0 & 188 & 4 & 0 \\
\hline 146 & 510 & 442 & 1 & 0 & 451 & 2 & 0 \\
\hline 147 & 143 & 124 & 0 & 0 & 124 & 0 & 0 \\
\hline 148 & NO DATA & & & & & & \\
\hline 150 & NO DATA & & & & & & \\
\hline Total & 9,801 & 5,895 & 34 & 1 & 5,738 & 68 & 11 \\
\hline
\end{tabular}


Table 8. Summary of selected responses from agencies collecting surface-water-quality data to questionnaire on quality control/quality assurance procedures and information on flow measurements at SWAMP sites

\section{Questionnaire}

Number
\begin{tabular}{|l|c|c|c|c|}
\hline $10 \mathrm{a}$ Were steps taken to insure to insure accuracy, & \multicolumn{2}{c}{$\begin{array}{c}\text { Response } \\
\text { Yes }\end{array}$} & \multicolumn{1}{c}{$\begin{array}{c}\text { Did not } \\
\text { answer }\end{array} \begin{array}{c}\text { Percent } \\
\text { responded }\end{array}$} \\
\hline $10 \mathrm{~b} \quad$ precision, & 30 & 2 & 2 & 94 \\
\hline $10 \mathrm{c} \quad$ comparability, and & 30 & 1 & 3 & 91 \\
\hline $10 \mathrm{~d} \quad$ representativeness of collected samples? & 29 & 1 & 4 & 88 \\
\hline
\end{tabular}

11 Do you follow a DEP-approved QA/QC protocol for sampling?

\begin{tabular}{l|l|l|l|}
27 & 3 & 4 & 88
\end{tabular}

\begin{tabular}{|l|r|r|r|r|}
\hline 12a Do you have quality assurance practices for recording data? & 28 & 3 & 3 & 91 \\
\hline $12 \mathrm{~b} \quad$ for reporting data? & 23 & 6 & 5 & 85 \\
\hline $12 \mathrm{c}$ What quality assurance practices do you use for recording data? & 2 & 1 & 30 & 9 \\
\hline $12 \mathrm{~d} \quad$ for reporting data? & 1 & 2 & 30 & 9 \\
\hline
\end{tabular}

\begin{tabular}{|l|r|r|r|r|}
\hline 16a Do you use EPA STORET remark codes? & 19 & 9 & 6 & 82 \\
\hline 16b Do you use other remark codes? & 5 & 18 & 11 & 68 \\
\hline 16c Has your use of remark codes changed in the past? & 1 & 11 & 22 & 35 \\
\hline 16d How do you interpret these codes? & 0 & 1 & 33 & 3 \\
\hline
\end{tabular}

\begin{tabular}{|l|c|c|c|c|}
\hline $18 \mathrm{a}$ Do you qualify data at the station level? & 11 & 12 & 11 & 68 \\
\hline $18 \mathrm{~b} \quad$ at sample level? & 18 & 6 & 10 & 71 \\
\hline $18 \mathrm{c}$ Do you make provisions for informing users of the quality of data? & 2 & 8 & 24 & 29 \\
\hline 18d What are the provisions? & 0 & 4 & 30 & 12 \\
\hline
\end{tabular}

20a Do you follow calibration procedures in lab analysis of data?

20b What are they?

\begin{tabular}{|r|r|r|r|}
\hline 26 & 3 & 5 & 85 \\
\hline 0 & 0 & 33 & 0 \\
\hline
\end{tabular}

21a Have lab analysis methods changed over the years?

$21 \mathrm{~b}$ If yes, were steps taken to insure the changes did not impair data

$21 \mathrm{c}$ What were the steps?

\begin{tabular}{|r|r|r|r|}
\hline 17 & 10 & 8 & 77 \\
\hline 13 & 5 & 14 & 25 \\
\hline 0 & 0 & 34 & 0 \\
\hline
\end{tabular}

\begin{tabular}{|l|l|l|l|l|}
\hline 22a Provide list of analytes, & 25 & 4 & 5 & 85 \\
\hline $22 \mathrm{~b} \quad$ detection limits, and & 25 & 4 & 5 & 85 \\
\hline 22c reporting units for analytical methods that you use & 24 & 3 & 7 & 79 \\
\hline
\end{tabular}

\begin{tabular}{|l|r|r|r|r|}
\hline 23a Do you measure field parameters? & 30 & 3 & 1 & 97 \\
\hline 23b What are the parameters? & 0 & 0 & 34 & 0 \\
\hline 23c What are the methods of analysis? & 0 & 0 & 34 & 0 \\
\hline 23d the reporting units? & 0 & 0 & 34 & 0 \\
\hline
\end{tabular}

\begin{tabular}{|l|r|r|r|r|}
\hline 24a Are calibration methods followed in the field? & 28 & 5 & 2 & 94 \\
\hline 24b What are they? & 0 & 0 & 34 & 0 \\
\hline 24c Are these stored? & 11 & 4 & 19 & 44 \\
\hline 24d Are these stored? & 13 & 2 & 19 & 44 \\
\hline
\end{tabular}

\begin{tabular}{|l|l|l|l|l|}
\hline 27a Is gage height recorded during sample collection? & 8 & 22 & 6 & 83 \\
\hline 27b Is discharge measured during sample collection? & 5 & 18 & 13 & 64 \\
\hline 27c Are tidal stages recorded for the collection of estuary samples? & 5 & 17 & 13 & 63 \\
\hline
\end{tabular}

\begin{tabular}{|l|r|r|r|r|}
\hline 28a Are samples collected at individual points (grab samples)? & 29 & 3 & 2 & 94 \\
\hline 28b Or are they integrated over depth or width (composited)? & 10 & 4 & 20 & 41 \\
\hline 28c Describe how composited? & 0 & 1 & 33 & 3 \\
\hline
\end{tabular}




\section{Appendix}




\section{FDEP Surface-Water Ambient Monitoring Program (SWAMP) Questionnaire}

\section{Monitoring Network}

1. Are you currently operating an ambient or regulatory surface-water-quality monitoring network? Please describe any other kind of network(s) you are currently operating.

2. How many fixed-stations or other ambient surface-water sites are being sampled as part of your program?

3. Have SWAMP sampling sites changed in the past? When?

4. How frequently do you sample each station and what criteria did you use to derive that frequency?

5. What criteria were used to select the sampling locations?

6. What criteria were used to select the variables of interest?

7. Do you have permanent staff available for sample collection and analysis?

8. Are any analyses or sampling efforts contracted out? If so, please list the name of the contract laboratory or sample-collection agency.

9. Are there any conditions under which you do not sample? Please describe.

10. What steps were taken to insure that samples are collected to insure accuracy, precision, comparability, and representativeness?

11. Do you follow a DEP-approved QA/QC protocol for sampling? If so, please provide CompQAPP number.

\section{Data Upload}

12. What quality assurance practices do you use for recording and reporting data?

13. Do you upload data to STORET? If so, for how long? < $1 \mathrm{yr} 1-5 \mathrm{yr} 5-10 \mathrm{yr}>10 \mathrm{yr}$ ?

14. Do you generally upload you data to STORET within one year of sample collection?

15. Do you upload data to any other databases? If so, please list.

16. Do you use the EPA STORET remark codes? Do you use other remark codes? Has you use of remark codes changed in the past? How do you interpret these codes?

18. Do you quality data at the station or sample level? What provisions do you make for informing users of the quality of the data?

19. In general, are you satisfied with STORET as a central repository for water-quality data?

\section{Laboratory Methods}

20. What calibration procedures are followed in the lab?

21. Have the methods of analysis changed over the years? What was done to insure that these changes have not impaired data comparability?

22. Please provide a list of analytes, detection limits, and reporting units for analytical methods that you use. (for example: Nitrate $0.005 \mathrm{mg} / \mathrm{L}$ as N EPA 352.1) 


\section{Field Methods}

23 . What parameters do you typically measure in the field?

24. What calibration methods are followed in the field? Are these recorded and stored somewhere?

25. Please provide a list of parameters you typically measure in the field. Please include the method of analysis and reporting units. (for example: Specific conductance -by probe uSiemens/cm).

26. Are samples collected from stations in any prescribed order or time of day?

27. Is gage height recorded or discharge measured during sample collection? Are tidal stages recorded for the collection of estuary samples?

28. Are samples collected at individual points (for example grab samples) or are they integrated over depth or width (composited)? If composited, please describe.

\section{Data Practices}

29. What are the main uses of your data? Do you make management decisions with the data?

30. What kinds of reports and publications do you produce with the data? Are you producing analytical reports? Data tables?

31. Who uses the surface-water-quality information that you produce?

32. Please list the names, phone numbers, and email addresses for those of your agency involved in SWAMP sample collection, lab analysis, and data management. 


\section{Appendix}




\section{FDEP Surface-Water Ambient Monitoring Program (SWAMP) Questionnaire}

\section{Monitoring Network}

1. Are you currently operating an ambient or regulatory surface-water-quality monitoring network? Please describe any other kind of network(s) you are currently operating.

2. How many fixed-stations or other ambient surface-water sites are being sampled as part of your program?

3. Have SWAMP sampling sites changed in the past? When?

4. How frequently do you sample each station and what criteria did you use to derive that frequency?

5. What criteria were used to select the sampling locations?

6. What criteria were used to select the variables of interest?

7. Do you have permanent staff available for sample collection and analysis?

8. Are any analyses or sampling efforts contracted out? If so, please list the name of the contract laboratory or sample-collection agency.

9. Are there any conditions under which you do not sample? Please describe.

10. What steps were taken to insure that samples are collected to insure accuracy, precision, comparability, and representativeness?

11. Do you follow a DEP-approved QA/QC protocol for sampling? If so, please provide CompQAPP number.

\section{Data Upload}

12. What quality assurance practices do you use for recording and reporting data?

13. Do you upload data to STORET? If so, for how long? < $1 \mathrm{yr} 1-5 \mathrm{yr} 5-10 \mathrm{yr}>10 \mathrm{yr}$ ?

14. Do you generally upload you data to STORET within one year of sample collection?

15. Do you upload data to any other databases? If so, please list.

16. Do you use the EPA STORET remark codes? Do you use other remark codes? Has you use of remark codes changed in the past? How do you interpret these codes?

18. Do you quality data at the station or sample level? What provisions do you make for informing users of the quality of the data?

19. In general, are you satisfied with STORET as a central repository for water-quality data?

\section{Laboratory Methods}

20. What calibration procedures are followed in the lab?

21. Have the methods of analysis changed over the years? What was done to insure that these changes have not impaired data comparability?

22. Please provide a list of analytes, detection limits, and reporting units for analytical methods that you use. (for example: Nitrate $0.005 \mathrm{mg} / \mathrm{L}$ as N EPA 352.1) 


\section{Field Methods}

23 . What parameters do you typically measure in the field?

24. What calibration methods are followed in the field? Are these recorded and stored somewhere?

25. Please provide a list of parameters you typically measure in the field. Please include the method of analysis and reporting units. (for example: Specific conductance -by probe uSiemens/cm).

26. Are samples collected from stations in any prescribed order or time of day?

27. Is gage height recorded or discharge measured during sample collection? Are tidal stages recorded for the collection of estuary samples?

28. Are samples collected at individual points (for example grab samples) or are they integrated over depth or width (composited)? If composited, please describe.

\section{Data Practices}

29. What are the main uses of your data? Do you make management decisions with the data?

30. What kinds of reports and publications do you produce with the data? Are you producing analytical reports? Data tables?

31. Who uses the surface-water-quality information that you produce?

32. Please list the names, phone numbers, and email addresses for those of your agency involved in SWAMP sample collection, lab analysis, and data management. 